Universidade de São Paulo

Escola Superior de Agricultura "Luiz de Queiroz"

Medições do saldo de radiação em copas de cafeeiros e limeiras ácidas por sistemas de integração espaço-temporal e estimativas por técnicas de modelagem

\title{
Jones Simon
}

Tese apresentada para obtenção do titulo de Doutor em Ciências. Área de Concentração: Física do Ambiente Agrícola

Piracicaba

2010 
Jones Simon

Engenheiro Agrônomo

Medições do saldo de radiação em copas de cafeeiros e limeiras ácidas por sistemas de integração espaço-temporal e estimativas por técnicas de modelagem

Orientador:

Prof. Dr. LUIZ ROBERTO ANGELOCCI

Tese apresentada para obtenção do título de Doutor em Ciências. Área de concentração: Física do Ambiente Agrícola

\section{Piracicaba}

2010 
Dados Internacionais de Catalogação na Publicação DIVISÃO DE BIBLIOTECA E DOCUMENTAÇÃO - ESALQ/USP

Simon, Jones

Medições do saldo de radiação em copas de cafeeiros e limeiras ácidas por sistemas de integração espaço-temporal e estimativas por técnicas de modelagem / Jones Simon. - Piracicaba, 2010.

112 p. : il.

Tese (Doutorado) - - Escola Superior de Agricultura “Luiz de Queiroz", 2010.

1. Balanço de energia 2. Cafeicultura 3. Citricultura 4. Modelagem de dados 5. Pomares Radiação - Energia radiante I. Título

CDD 633.73

S595m

“Permitida a cópia total ou parcial deste documento, desde que citada a fonte - O autor" 
Aos meus pais, EDITE e MARIO,

e minha irmã UANA, com

muito amor, carinho e gratidão

OFEREÇO

À minha FAMÍLIA e AMIGOS, DEDICO. 


\section{AGRADECIMENTOS}

À Deus, pela vida, força e sabedoria, para manter-me firme nos meus objetivos.

Ao professor Dr. Luiz Roberto Angelocci, não somente, um orientador, mas também amigo e em alguns momentos um pai, pela orientação, ensinamentos, oportunidades e incentivos para meu amadurecimento profissional.

Ao professor Dr. Paulo César Sentelhas pela amizade, ensinamentos e pela oportunidade de ingresso no doutorado direto.

Aos demais professores do curso de pós-graduação em Física do Ambiente Agrícola, pela amizade, exemplo de profissionalismo e pelos valiosos ensinamentos transmitidos.

Aos professores Dr. Sandro Luis Petter Medeiros e Dr. Paulo Augusto Manfron, da Universidade Federal de Santa Maria - UFSM, amigos e incentivadores da escolha de expandir horizontes.

Aos amigos e colegas de curso pela amizade e convívio e pelos cafezinhos da tarde, na cozinha da cúpula ao longo desses anos.

Aos colegas Fábio e Andréa, que além da amizade, destinaram um pouco do seu precioso tempo para dar um apoio de campo.

Aos funcionários dos Departamentos de Ciências exatas e Engenharia de Biossistemas pela ajuda, não somente profissional, mas pessoal; e principalmente ao Edivaldo Modesto de Abreu e Francisco dias que ao longo do tempo estavam sempre presentes a auxiliar.

À Escola de Agricultura "Luiz de Queiroz" por ser casa ao longo desse tempo.

À CAPES pela concessão da bolsa de doutorado ao longo de todo período. 
Ao CNPq pelo suporte financeiro na construção dos equipamentos.

Aos doutores Felipe Gustavo Pilau, Ricardo Oyarzun e Rogério Costa Campos, pela disposição e grande ajuda na construção desse conhecimento.

Aos amigos Fernando, Evandro, Derblai, Manoel, Rafael Vivian, Rafael P. Bortolotto e Christian que ao longo do tempo dividiram responsabilidades e bons momentos na República Espeto do Sul.

Às demais pessoas que direta ou indiretamente contribuíram para a conclusão deste trabalho. 


\section{SUMÁRIO}

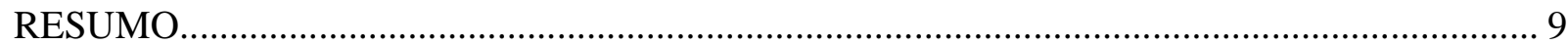

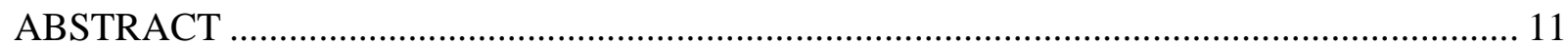

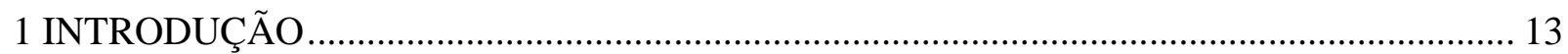

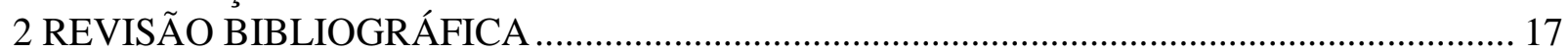

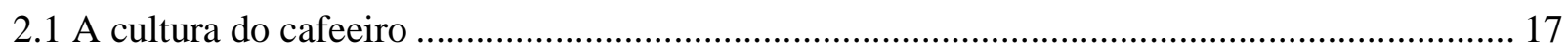

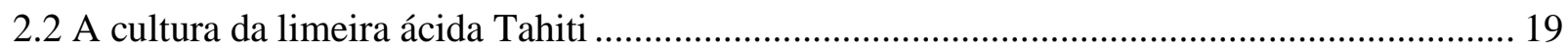

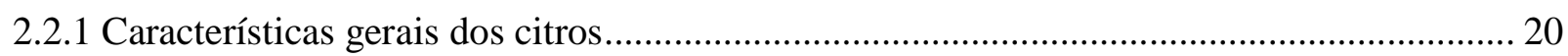

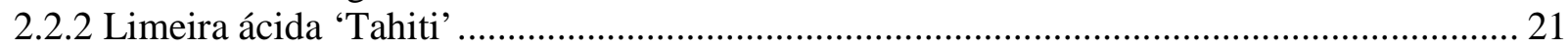

2.3 Importância da interceptação de radiação solar pelas plantas .................................................. 22

2.4 Medida do saldo de radiação em comunidades vegetais ..................................................... 23

2.5 Estimativa do saldo de radiação solar em copas de lenhosas ............................................... 27

2.5.1 Relação entre o saldo de radiação de plantas, irradiância solar global e saldo de radiação de

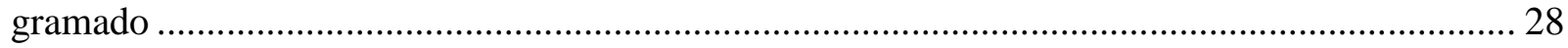

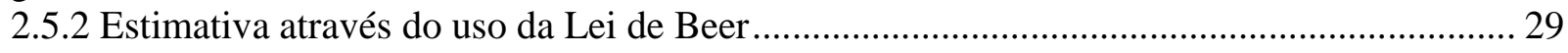

2.5.3 Estimativa do saldo de radiação por modelagem física-matemática.................................... 32

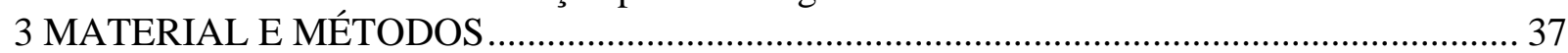

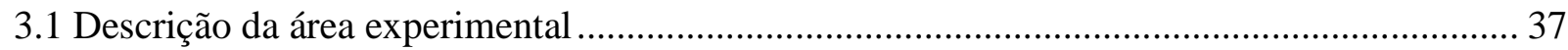

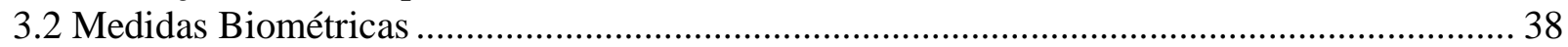

3.3 Descrições dos sistemas integradores do saldo de radiação de trechos de renque .................. 39

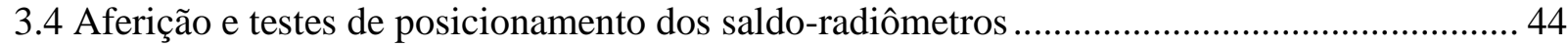

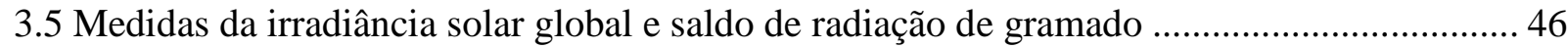

3.6 Determinação da radiação solar direta e difusa por modelo proposto.................................... 46

3.7 Estimativa do saldo de radiação para limeira ácida 'Tahiti' e renque de cafeeiros utilizando a

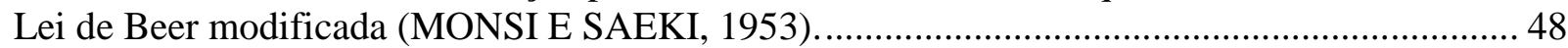

3.8 Modelo para estimativa de saldo de radiação em renques (RIOU, VALANCOGNE E PIERI,

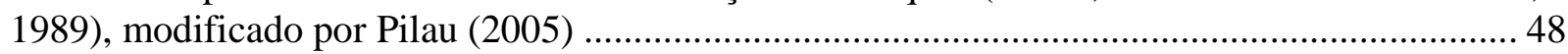

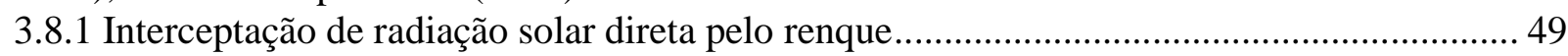

3.8.2 Interceptação de radiação solar difusa pelo renque ...................................................... 51

3.9 Modelo de interceptação da radiação em pomares (OYARZUN , 2005) ................................ 53

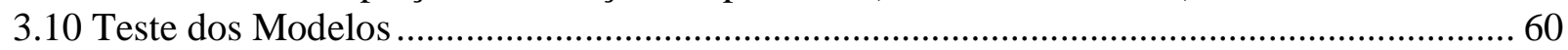

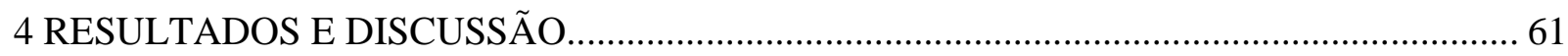

4.1 Teste de balanceamento (desvio do zero) dos sensores no sistema móvel............................. 61

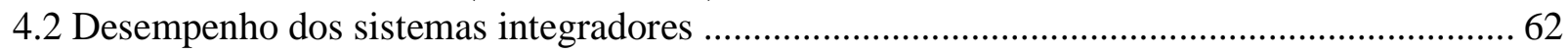

4.3 Variação temporal do saldo de radiação em renques em função da posição dos saldo-

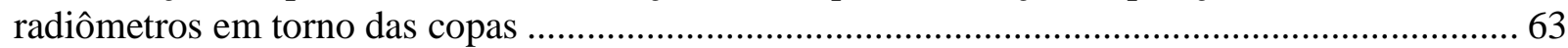

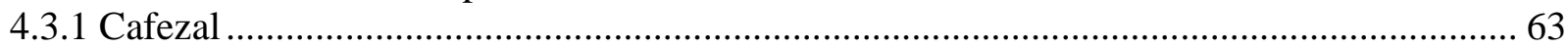

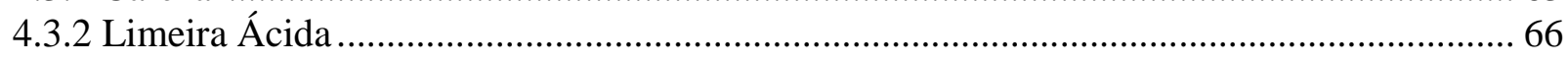

4.4 Relações do saldo de radiação dos renques com a irradiância solar global e o saldo de

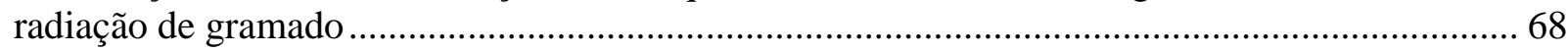

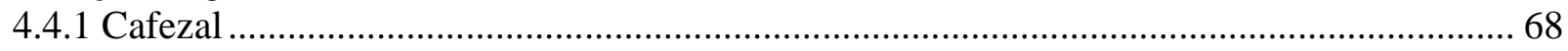

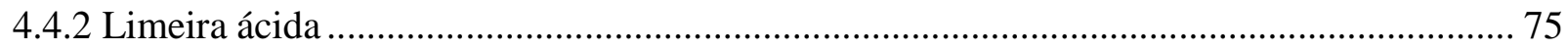

4.5 Estimativa do saldo de radiação em renques pelo uso da lei de Beer .................................... 80

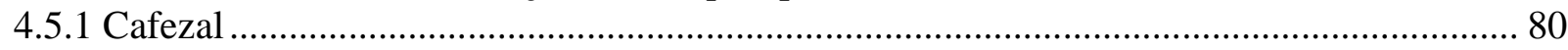

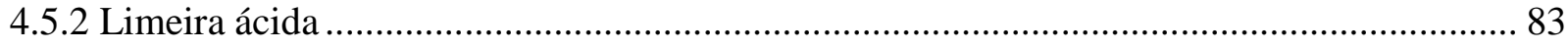


4.6 Desempenho do modelo proposto por Pilau (2005) para estimativa do saldo de radiação das copas 85

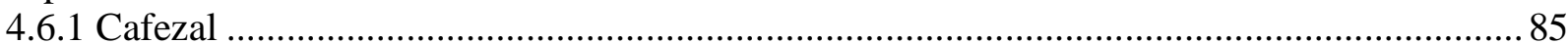

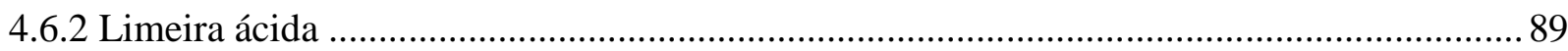

4.7 Estimativa do saldo de radiação pelo modelo proposto por Oyarzun (2005) .......................... 92

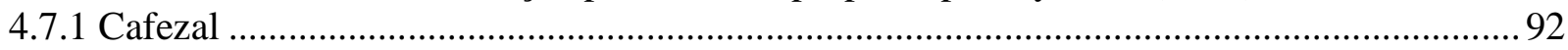

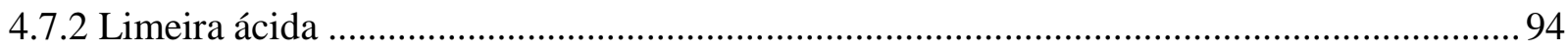

4.8 Comparação entre modelos de estimativa do saldo de radiação de copas .............................. 96

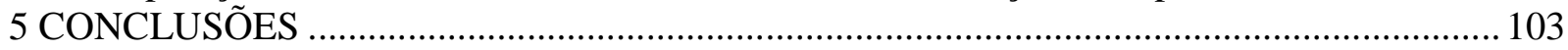

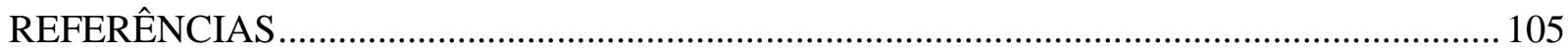




\section{RESUMO}

\section{Medições do saldo de radiação de copas de cafeeiros e de limeiras ácidas em renques por sistemas de integração espaço-temporal e estimativas por técnicas de modelagem}

A energia radiante absorvida pelas copas tem aplicação em estudos de fotossíntese e transpiração de plantas arbóreas. Sua determinação não é simples. Nas últimas duas décadas tem sido realizados trabalhos sobre interceptação de radiação por espécies arbóreas isoladas ou em renques, envolvendo tanto radiação de ondas curtas como de ondas longas (saldo de radiação, $\mathrm{Rn}$ ). Uma técnica de medida de Rn utiliza radiômetros movendo-se em torno da copa de uma árvore (geometria esférica de medida) ou ao longo de copas de um renque (geometria cilíndrica). Uma alternativa é o uso de modelagem físico-matemática para estimativa de $\mathrm{Rn}$, que também exige medidas para testar modelos. Considerando os poucos trabalhos nessa linha de pesquisa, o presente estudo objetivou: a) avaliar o desempenho de sistemas móveis de integração espaçotemporal de medidas de $\mathrm{Rn}$ em renque de um cafezal e de um pomar de limeira ácida localizados no Campus "Luiz de Queiroz", USP, Piracicaba, SP; b) estabelecer relações do saldo de radiação das copas de cafeeiros (Rnc) e limeiras ácidas (Rnl) com o saldo de radiação de gramado (Rng) e irradiância solar global (Rg); c) avaliar o desempenho de três modelos físicomatemáticos de estimativa de Rn por comparação com as medidas realizadas com varredura da copa pelos saldo-radiômetros movimentando-se ao longo dos renques (geometria cilíndrica de medidas). Os estudos foram realizados nas quatro estações do ano e em três no pomar, iniciandose respectivamente no outono e no verão de 2008. Os sistemas integradores forneceram valores diários de magnitude coerentes com os de calor latente de vaporização da copa determinados por medidas de transpiração de uma árvore. O desempenho do sistema de grande porte utilizado no pomar exige testes adicionais. O curso diário de $\mathrm{Rn}$ em cada posição dos radiômetros em torno da copa mostraram padrões diferenciados conforme orientação do renque e época do ano. No cafezal foram encontradas muito boas relações de Rnc com Rg e Rng nas escalas de 15min, horária e diurna, exceto no verão para $15 \mathrm{~min}$ e horária e no inverno, na escala diurna, para Rng. Para o pomar, as relações de Rnl com Rg e Rng foram boas nas três escalas temporais, exceto no verão para $15 \mathrm{~min}$ e horária e no outono na escala diurna. Para o cafezal o modelo de Beer apresentou altos índices de confiabilidade nas épocas do ano, nas escalas horária e diurna; e no pomar se mostrou confiável para inverno, mas não no verão na escala diurna e na escala horária apresentou menor confiabilidade. O modelo de Pilau apresentou boa confiabilidade para o cafezal no outono e menor confiabilidade nas demais estações, enquanto na escala horária verificou-se boa confiabilidade no outono e inverno; para o pomar, o desempenho foi satisfatório para inverno nas duas escalas temporais e insatisfatório para verão na escala diurna. Para o cafezal o modelo de Oyarzun mostrou-se confiável na escala diurna, e menos confiável na escala horária no verão; para o pomar, apresentou boa confiabilidade em ambas escalas temporais no inverno e baixa confiabilidade no verão.

Palavras chave: Saldo de radiação; Irradiância solar; Lei de Beer; Modelagem; Pomar; Cafeicultura; Citricultura 


\section{ABSTRACT \\ Measurements of net radiation of the canopy of coffee and acid lime trees in hedgerows by spatiotemporal integration systems and estimates by modelling techniques}

The amount of radiant energy absorbed by the canopy of trees has great application in photosynthesis and transpiration research. Studies of radiation interception by the canopies of an isolated or a sequence of trees in hedgerows have been carried out by a technique which employs moving radiometers around an isolated tree ("spherical geometry of measurement") or along a part of a hedgerow ("cylindrical geometry"). This technique allows spatiotemporal integration of the values. Crop Modeling is an alternative approach to estimate the radiation balance of canopies (Rn). The present study had the following objectives: a) to evaluate the performance of systems for spatiotemporal integration of Rn measurements in hedgerows of a coffee and an acid lime crops at the "Luiz de Queiroz" Campus of the University of São Paulo, in Piracicaba, SP, Brazil; b) to establish relations of the net radiation of the coffee (Rnc) and of acid lime plants (Rnl) canopies with grass net radiation (Rng) and incoming solar radiation (Rg); c) to evaluate the performance of three models of Radiation Balance $(\mathrm{Rn})$, by comparing modem results with measurements by the moving radiometers along the planting row ("cylindrical geometry"). The coffee experiment was carried out all year long starting in the fall of 2008 while for the orchard only three seasons were tested starting in the summer 2008. Measurements of $\mathrm{Rn}$ by the moving systems were considered reliable, but it is recommended further testing of that of the orchard. The daily course of Rn for each measurement around the canopy showed different patterns for the two crops, in agreement with planting row orientation and season. Concerning to relations of Rnc with Rg and Rng integrated for $15 \mathrm{~min}$, hourly and diurnal periods, they were very good for the coffee crop in the three timescales, excepting for the $15 \mathrm{~min}$ and hourly timescales in the summer and for the Rng for the diurnal period in the winter. For the orchard, the relations of Rnl with Rg and Rng were good, excepting for the summer in the $15 \mathrm{~min}$ and hourly and in autumn for the diurnal timescales. The Beer's model showed good reliability for the coffee crop; while for the orchard it showed to be reliable in the winter, but not in the summer for the diurnal period; for the hourly periods it was less reliable. The Pilau's model showed good reliability for the coffee crop for both the diurnal and hourly periods during the fall, but less reliability in the other seasons; for the orchard, its performance was reliable for the winter in the two timescales and not reliable for the summer in the diurnal scale. The Oyarzun's model showed to be reliable in the diurnal timescale and less reliable in the hourly timescale for the summer; for the orchard, it showed good reliability for the winter and little reliability for the summer.

Keywords: Net radiation; Solar irradiance; Grass net radiation; Modeling; Beer's law; Orchard; Coffee cropping; Citrus cropping 


\section{INTRODUÇÃO}

Desde sua introdução no país, a cultura do café apresenta-se como uma das mais importantes "commodities" da economia agrícola brasileira, representando uma significante fonte de renda do setor rural, com um alto valor agregado, como produto de exportação e uma alta demanda no mercado interno. Atualmente o Coffea arabica L. representa $65 \%$ da área de produção, enquanto Coffea canephora cv. Pierre ocupa o restante das áreas. A produção agrícola na safra 2003/04 esteve próxima de 20 milhões de sacas de $60 \mathrm{~kg}$, enquanto na safra anterior havia chegado a 48,5 milhões de sacas. Essa baixa na produção ocorreu devido às condições climáticas desfavoráveis a cultura, particularmente a limitada oferta de água (DAMATTA, 2004).

Regiões consideradas anteriormente impróprias, por apresentarem elevado déficit hídrico durante o ano, agora se apresentam como as mais competitivas, destacando-se o Triângulo Mineiro, Alto Paranaíba, Norte do Espírito Santo e Oeste da Bahia. Essa competitividade foi gerada pelo uso da suplementação hídrica, e por meio deste manejo, a deficiência hídrica pode ser minimizada. Para que a aplicação de água seja eficiente é de fundamental importância que se conheça a adequada demanda hídrica da cultura. Esta, por sua vez, é regulada pelas características biológicas da planta e pelo clima da região.

A limeira ácida 'Tahiti', que é comumente conhecida pela maioria dos produtores como "limão Tahiti”, vem se destacando como uma atividade rentável nos últimos anos, passando assim a ser mais uma opção para os produtores de algumas regiões. E com o aumento da importância da cultura na economia destas regiões as pesquisas começaram a crescer, beneficiando o aumento do conhecimento e a criação de novas técnicas aplicadas à cultura do Tahiti. A limeira ácida produzida nestas regiões tem como objetivo os mercados interno e externo, sendo que as exigências para o mercado externo têm sido um pouco maiores no que concerne às práticas de produção sustentável. O "limão Tahiti” tem uma característica de variação de preços ao longo dos meses do mesmo ano, o que na maioria das vezes determina o sucesso da cultura. Assim, os produtores têm saído à busca de clones, porta-enxerto e técnicas de produção, que levem às maiores produções em épocas de preços melhores. Dentre as técnicas prioritárias estão: a irrigação e a adequação do pomar a um regime radiativo mais eficiente para aumentar quantidade e melhorar a qualidade dos frutos. 
A energia radiante absorvida por uma planta é o principal determinante de sua taxa fotossintética e da perda de água através da transpiração (ANNANDALE et al., 2004; GREEN et al., 2003) e, juntamente a fatores complementares como temperatura do ar e do solo, disponibilidade hídrica e nutrição mineral, condiciona o crescimento e o desenvolvimento vegetal, suas produções e a qualidade destes produtos.

Nos estudos de relações hídricas de culturas, envolvendo perda de água, o saldo de radiação é fundamental, pois é o principal fator energético do processo evapotranspiratório. Poucos estudos são realizados sobre a dinâmica do saldo de radiação em culturas agrícolas, e a grande maioria, concentrado em culturas com distribuição "contínua" da cobertura sobre o solo.

Com o advento da irrigação localizada, utilizada principalmente para coberturas vegetais “descontínuas", como pomares, cafezais, etc., tem havido um crescente interesse em se determinar a interceptação da radiação e o saldo de energia radiante tanto da cobertura vegetal como um todo, mas também de partes constituintes, como a vegetação das linhas e entrelinhas de plantio. A energia radiante absorvida pelas copas das árvores constituintes dessas coberturas é uma variável de interesse em estudos de balanço de carbono (fotossíntese) e de transpiração de plantas de interesse econômico em pomares e cafezais, por exemplo, nos quais são encontradas densidades de plantios que levam à distribuição de plantas "isoladas" (com espaçamento largo e pouca interferência entre elas quanto ao balanço de energia radiante) ou em renques com adensamento do número de plantas na linha de plantio (folhagem contínua na linha de plantio, pelo fato das copas chegarem a se tocar).

A determinação do saldo de radiação das copas das árvores, sejam isoladas ou em renques, é mais complexa do que a determinação para toda a cobertura vegetal, pois a própria geometria de plantio e da copa, o porte da cultura e sua área foliar são fatores que afetam as trocas radiativas e determinam dificuldades nas medidas, exigindo procedimentos e técnicas diferenciadas, como aparatos móveis e instrumentação adequadas. A dificuldade nessas medidas tem conduzido à tentativa de desenvolvimento de modelos de estimativa de interceptação de radiação solar por dosséis vegetativos e mesmo da absorção de energia radiante de ondas curtas e de ondas longas, com a finalidade de viabilizar o uso prático dessa variável, tanto em pesquisa como em sistemas produtivos. Mas, a própria validação de modelos físicos-matemáticos, e daqueles baseados em regressões lineares simples, que levam em considerações outras variáveis determinantes do saldo de radiação, como área foliar, porosidade do dossel, irradiância solar 
global, etc., exigem medidas diretas da interceptação da radiação solar ou mesmo da absorção de energia radiante em todos os comprimentos de onda pelas plantas.

A literatura mostra algumas tentativas de desenvolvimento de técnicas de medidas e de desenvolvimento de modelos de estimativa da interceptação de radiação nesses tipos de dosséis. Quanto às técnicas, há exemplos de uso de sensores fixos em torno de renques (LANDSBERG et al., 1975; THORPE, 1978), ou posicionados acima e abaixo do dossel (ANNANDALE et al. 2004; OYARZUN et al., 2007). Uma técnica proposta por McNaughton et al. (1992) em Palmerston, Nova Zelândia, faz uso de sensores móveis (tanto saldo radiômetros, quanto quantômetros) girando em torno da copa de uma árvore "isolada" para integrar espaçotemporalmente a absorção de radiação pela copa da árvore, tendo sido utilizada, também, em Piracicaba, SP para duas espécies de citros (ANGELOCCI et al., 1999, PILAU, 2005; PILAU et al., 2007). Uma modificação dessa técnica foi utilizada neste local para movimentar saldoradiômetros ao longo da linha de renques de cafeeiros (MARIN, 2003; ANGELOCCI et al., 2008) integrando a radiação absorvida por plantas alinhadas no renque, tendo-se verificado sua potencialidade.

Por outro lado, vários modelos físico-matemáticos e de regressão entre o saldo de radiação de copas de lenhosas, tanto com árvores isoladas ou em plantio adensado em linhas (renques) e variáveis radiométricas têm sido desenvolvidos (PALMER, 1989; WANG E JARVIS, 1990; McNAUGHTON et al., 1992, GREEN et al., 2003; ANNANDALE et al., 2004; ANGELOCCI et al., 2004; PILAU, 2005; PEREIRA, GREEN E VILLA NOVA, 2006), havendo tentativas de sua validação a partir de medidas com sensores fixos ou móveis.

Considerando que há poucos trabalhos publicados tanto quanto às técnicas de medida, como quanto ao desenvolvimento de modelos de estimativa de absorção de energia radiante por renques de coberturas vegetais descontínuas, o presente estudo baseia-se em duas premissas: a) a técnica de medida envolvendo determinação de um trecho de renque, desenvolvida em Piracicaba, SP, é de uso prático na investigação científica e apresenta resultados confiáveis para estudos desse tipo, inclusive para o teste de modelos; b) os modelos de estimativa de saldo de radiação de dosséis vegetativos na forma de linhas adensadas de plantio são válidos e seria interessante estudar os mais práticos e de menor complexidade, para que tenham aplicabilidade.

Com isso em mente, o presente trabalho apresenta os resultados do estudo em um cafezal e um pomar de limeira ácida, ambos adultos, tendo por objetivos: a) avaliação do desempenho de 
sistemas móveis de medidas do saldo de radiação, integrado espacial e temporalmente para várias árvores de uma linha de plantio em cada cobertura vegetal; b) verificar as relações entre o saldo integrado para as copas nas duas culturas com o saldo de radiação de um gramado e com a irradiância solar global, considerando-se diferentes estações do ano, como uma forma de facilitar as estimativas a partir de duas variáveis medidas em estações meteorológicas; c) avaliar o desempenho de três modelos físico-matemáticos, em comparação com as medidas pela técnica apresentada.

O presente pretende contribuir com o aumento do conhecimento sobre o assunto pelas seguintes diferenças ou adições em relação aos anteriores realizados em Piracicaba: a) introdução de medidas em citros com a técnica de varredura do renque ("geometria cilíndrica"), em oposição à geometria de varredura em torno de uma única árvore ("geometria esférica"), com construção e avaliação do desempenho de um sistema móvel de considerável dimensão; b) estudo em cafezal com 8-9 anos após implantação, com determinações nas várias estações do ano; c) uso de duas coberturas com diferentes direções de linhas de plantio. 


\section{REVISÃO BIBLIOGRÁFICA}

\subsection{A cultura do cafeeiro}

O cafeeiro (Coffea sp.) é um arbusto da família Rubiaceae e do gênero Coffea L. , da qual se conhecem atualmente 103 espécies e se colhem sementes para estudos de melhoramento. $\mathrm{O}$ café é largamente cultivado em países tropicais, tanto para consumo próprio como para exportação para países de clima temperado. O Brasil é o maior produtor e exportador mundial de café, seguido pelo Vietnam e Colômbia. As plantações comerciais de café estão mundialmente distribuídas desde o Havaí $\left(20^{\circ}\right.$ a $\left.25^{\circ} \mathrm{N}\right)$, passando por Cuba $\left(22^{\circ} \mathrm{N}\right)$, até o estado do Paraná no Brasil $\left(22^{\circ}\right.$ a $\left.23^{\circ} \mathrm{S}\right)$ nas Américas, estendendo-se também na África desde o oeste até o Lago Victória (CARR, 2001).

Duas espécies se destacam na utilização comercial: Coffea arabica L. e Coffea Canephora. Coffea arabica é uma espécie de café natural da Etiópia, supostamente uma das primeiras espécies de café a ser cultivada e atualmente representa $70 \%$ da produção mundial. Produz cafés de qualidade, finos e requintados, e possui aroma intenso e os mais diversos sabores, com inúmeras variações de corpo e acidez. Coffea canephora (Coffea robusta) é uma espécie de café originária da África Ocidental. É cultivada principalmente na África e no Brasil onde é chamada por vezes de Conillon (DAMATTA E RAMALHO, 2006). É cultivada no Sudeste asiático onde os colonizadores franceses a introduziram em finais do séc. XIX. Nos últimos anos o Vietnam, que produz apenas robusta, ultrapassou o Brasil, a Índia e a Indonésia como o maior exportador mundial dessa espécie. Aproximadamente um terço do café produzido no mundo é Coffea robusta.

O café chegou ao Brasil em Belém do Pará, expandindo-se logo em seguida para regiões do Maranhão, Ceará, Vale do São Francisco, Goiás, Minas Gerais, Espírito Santo e Rio de Janeiro (TASSARO, 1996). Hoje os maiores produtores de café são os estados de Minas Gerais, Espírito Santo, São Paulo, Paraná, Bahia e Rondônia (Associação Brasileira da Indústria de Café - ABIC, 2005). Desde sua introdução no país, a cultura do café apresenta-se como uma das mais importantes "commodities" da economia agrícola brasileira, representando uma significante fonte de renda do setor rural, com um alto valor agregado, como produto de exportação e uma alta demanda no mercado interno. Atualmente o Coffea arabica L. representa $72 \%$ da área de 
produção, enquanto Coffea canephora cv. Pierre ocupa o restante das áreas. A produção agrícola na safra 2008/09 esteve próxima de 39,1 milhões de sacas de $60 \mathrm{~kg}$ de café beneficiado, enquanto na safra anterior havia chegado a 46 milhões de sacas. Essa baixa de 15\% na produção, toda ela verificada para a espécie arábica, ocorreu devido às condições climáticas desfavoráveis a cultura, particularmente a limitada oferta de água e as elevadas temperaturas (CONAB, 2009).

Regiões consideradas anteriormente impróprias, por apresentarem elevado déficit hídrico durante o ano, agora se apresentam como as mais competitivas, destacando-se o Triângulo Mineiro, Alto Paranaíba, Norte do Espírito Santo e Oeste da Bahia. Essa competitividade foi gerada pelo uso da suplementação hídrica, e por meio deste manejo, a deficiência hídrica pode ser minimizada. Para que a aplicação de água seja eficiente é de fundamental importância que se conheça a adequada demanda hídrica da cultura. Esta, por sua vez, é regulada pelas características biológicas da planta e pelo clima da região.

Um fator ambiental limitante ao crescimento do cafeeiro é a temperatura do ar. Temperaturas inferiores a $5^{\circ} \mathrm{C}$ provocam sérios danos às plantas, registrando-se a morte dessas na ocorrência de temperaturas negativas. Semelhantemente, temperaturas médias acima de $30^{\circ} \mathrm{C}$ podem ser letais. As zonas ótimas para a cultura do cafeeiro arábica caracterizam-se por temperaturas médias anuais entre $18^{\circ}$ e $21^{\circ} \mathrm{C}$ (ALÈGRE, 1959). Acima de $23^{\circ} \mathrm{C}$, o desenvolvimento e amadurecimento dos frutos são acelerados, freqüentemente causando perda da qualidade (CAMARGO, 1985). Para o cafeeiro robusta, as temperaturas médias anuais estão entre $22^{\circ}$ a $26^{\circ} \mathrm{C}$ (MATIELLO, 1998), ou de acordo com Willson (1999), de $24^{\circ}$ a $30^{\circ} \mathrm{C}$. Altas temperaturas são prejudiciais, especialmente se o ar estiver muito seco (COSTE, 1992). O cafeeiro robusta é muito menos adaptável a baixas temperaturas que o arábica. Folhas e frutos não resistem a temperaturas abaixo de $5-6^{\circ} \mathrm{C}$ ou longos períodos com temperaturas de $15^{\circ} \mathrm{C}$ (WILLSON, 1999). O robusta se desenvolve bem desde o nível do mar até 800m de altitude, enquanto o arábica se desenvolve melhor em altas altitudes e áreas montanhosas, como na Colômbia e América Central.

O regime pluviométrico é o outro grande fator ambiental limitante, sendo adequado de 1200 a 1800 mm por ano para o cafeeiro arábica (ALÈGRE, 1959). As mesmas exigências são requeridas para a espécie robusta, embora ela se adapte a regimes excessivos de umidade, ultrapassando os $2000 \mathrm{~mm}$ anuais (COSTE, 1992). Para ambas as espécies, um curto período de seca, ao redor de 2 a 4 meses, correspondente a fase de quiescência, é importante para estimular o 
florescimento (HAARER, 1958). Na ocorrência de um regime pluviométrico inferior a $1000 \mathrm{~mm}$, recomenda-se uma suplementação via irrigação (CARDOSO, 1994). Por ser uma planta originalmente de ambiente sombreado, dos sub-bosques de florestas da Etiópia, a saturação luminosa da cultura é baixa, considerando-se os elevados valores de radiação fotossinteticamente ativa (RFA) com densidade de fluxo de fótons fotossintéticos atingido valores máximos ao redor de $2.500 \mu \mathrm{mol} . \mathrm{m}^{-2} . \mathrm{s}^{-1}$, encontrados nos trópicos. Folhas expostas diretamente à radiação solar saturam-se à aproximadamente $600 \mu \mathrm{mol} \cdot \mathrm{m}^{-2} \cdot \mathrm{s}^{-1}$, e folhas sombreadas a $300 \mu \mathrm{mol} \cdot \mathrm{m}^{-2} \cdot \mathrm{s}^{-1}$ (KUMAR E TIESZEN, 1980; FAHL E CARELLI, 1994).

O ciclo fenológico dos cafeeiros da espécie Coffea arabica L. apresenta uma sucessão de fases vegetativas e reprodutivas que ocorrem em aproximadamente dois anos, diferentemente da maioria das plantas que emitem as inflorescências na primavera e frutificam no mesmo ano fenológico (CAMARGO, 1985). A cultura apresenta ciclo bienal, alternando anos de altas e de baixas produtividades (CAMARGO E CAMARGO, 2001). O cafeeiro, originalmente cultivado em espaçamentos amplos entre plantas, cobrindo menos de 50\% da superfície do solo, com até 3.000 plantas.ha ${ }^{-1}$, a partir da década de 80 passou a ser também cultivado em sistema adensado, com 3.000 à 7.000 plantas.ha $^{-1}$, ou até mesmo em super-adensamento, com densidade de plantio superando 7.000 plantas.ha ${ }^{-1}$. Nesses sistemas adensados, normalmente as plantas são agrupadas formando contínuos vegetados denominados de renques. Devido aos espaçamentos reduzidos, necessita-se escolher criteriosamente as variedades aptas a essas áreas, dando preferência às de porte menor, como as variedades IAC-Catuaí Vermelho e IAC-Catuaí Amarelo, consideradas apropriadas para esses cultivos. Já as cultivares de porte alto como Mundo Novo, Icatu Vermelho e Icatu Amarelo, Acaiá e Bourbon Amarelo, são menos indicadas, pois pelo próprio porte, fecham mais rapidamente, exigindo podas mais cedo (THOMAZIELLO, 2001).

\subsection{A cultura da limeira ácida Tahiti}

O cultivo de limeira ácida 'Tahiti', que é comumente conhecida pela maioria dos produtores como "limão Tahiti", vem se destacando como uma atividade rentável nos últimos anos, passando assim a ser mais uma opção para os produtores de algumas regiões. E com o aumento da importância da cultura na economia destas regiões as pesquisas começaram a crescer, beneficiando o aumento do conhecimento e a criação de novas técnicas aplicadas à cultura. $\mathrm{O}$ 
"limão Tahiti" produzido nestas regiões tem como objetivo os mercados interno e externo, sendo que as exigências para o mercado externo têm sido um pouco maiores no que concerne às práticas de produção sustentável. O "limão Tahiti” tem uma característica de variação de preços ao longo dos meses do mesmo ano, o que na maioria das vezes determina o sucesso da cultura. Assim, os produtores têm saído à busca de clones, porta-enxerto e técnicas de cultivo, que levem às maiores produções em épocas de preços melhores. Dentre as técnicas prioritárias estão a irrigação e a adequação do pomar a um regime radiativo mais eficiente para aumentar quantidade e melhorar a qualidade dos frutos.

\subsubsection{Características gerais dos citros}

Os citros procedem originariamente das zonas tropicais úmidas do sudeste da Ásia, porém a produção comercial em grande escala encontra-se nas zonas subtropicais sob irrigação. Além de serem produzidos para o consumo como fruta fresca e suco, os citros são cultivados também para a produção de óleo e ácido cítrico (DOORENBOS E KASSAM, 1979).

É uma espécie não caducifólia, com contínua reposição de folhas, as quais sobrevivem, em alguns casos, por períodos maiores que dois anos. Em condições climáticas ideais são capazes de elevada transpiração, que fica limitada em ambientes desfavoráveis, devido ao fechamento dos estômatos.

Em geral, as plantas cítricas desenvolvem-se em regiões de clima subtropical, quando as baixas temperaturas no inverno induzem a dormência e um período de diferenciação floral, seguido de um intenso florescimento na primavera. A duração do florescimento é fortemente dependente da temperatura. Sob condições de clima mais quente as flores se abrem dentro de poucos dias, resultando em uma concentração do florescimento, queda e pegamento de frutos. Entretanto, sob condições de temperaturas amenas o período pode se estender, obtendo-se um florescimento difuso (SPIEGEL-ROY E GOLDSCHMIDT, 1996; COELHO et al., 2004).

O fator de maior influência, em condições tropicais, parece ser o estresse hídrico. Segundo Pire, Bautista e Rojas (1993), o florescimento é influenciado naturalmente pela sucessiva ocorrência de período de chuva e seca. Na Itália, o estresse hídrico durante o verão é uma prática comum para indução floral na cultura do limão e uma vez ocorrido o florescimento é igualmente importante à manutenção de uma quantidade adequada de água disponível no solo 
(BARBERA, FATTA DEL BOSCO E LO CASCIO, 1985).

\subsubsection{Limeira ácida 'Tahiti'}

É uma espécie americana, tendo sua origem na Califórnia, Estados Unidos, onde surgiu a partir de sementes de limão introduzidas do Tahiti, por volta de 1870. Sua cultura se difundiu pelos países das três Américas, continente onde o limão Tahiti é produzido comercialmente. A limeira ácida é caracterizada por frutos grandes e, quase totalmente desprovida de sementes. Esta última característica se deve provavelmente a sua origem genética, um híbrido triplóide $(3 \mathrm{n}=$ 27). A floração ocorre durante quase todo ano, principalmente nos meses de setembro a outubro. É, dentre as espécies cítricas, a de maior precocidade, apresentando, em geral uma produção significativa já a partir do terceiro ano, mas, só a partir do quinto em diante é que começa a expressar rendimentos econômicos. No estado de São Paulo, essa cultura se adapta bem em quase todas as regiões, com exceção para aquelas onde a carência térmica limita o seu desenvolvimento (ORTOLANI, PEDRO JR E ALFONSI, 1991).

As plantas mantêm-se com folhas durante todo seu ciclo vegetativo e por essa razão transpiram o ano todo. Evidentemente que tal taxa de transpiração varia com os fatores climáticos como temperatura do ar, umidade relativa, vento, etc., e com o estado de vegetação floral, tais taxas são elevadas, condicionando maior exigência hídrica da cultura.

Dentre os fatores climáticos, a temperatura é o de maior importância, não apenas pela influência que exerce sobre o desenvolvimento das plantas e qualidade dos frutos, mas também por impor limites à expansão da cultura. Como a maioria das espécies do gênero Citrus, o limão Tahiti, sob temperaturas constantes, na faixa de 12 a $13^{\circ} \mathrm{C}$, tem seu desenvolvimento reduzido, sendo que a $5^{\circ} \mathrm{C}$, tem seu crescimento paralisado. Na faixa de 23 a $31^{\circ} \mathrm{C}$, seu crescimento alcança a taxa máxima, detendo-se, contudo, sob temperaturas acima de $39^{\circ} \mathrm{C}$, na qual começam ocorrer danos fisiológicos. A temperatura condiciona também o amadurecimento dos frutos (ORTOLANI, PEDRO JR E ALFONSI , 1991).

O ponto de saturação luminosa da cultura é baixo com valores de densidade de fluxo de fótons fotossintéticos (DFFF) de $700 \mu \mathrm{mol} \cdot \mathrm{m}^{-2} \mathrm{~s}^{-1}$. Nas regiões tropicais, a RFA normalmente atinge o ponto de saturação ao longo de todo o ano, o que resulta em maior e mais rápido crescimento das plantas e dos frutos, enquanto que nas regiões subtropicais, onde a variação 
sazonal de RFA é notória, o crescimento das plantas e dos frutos é mais lento e menor, devido à oscilação nas taxas de fotossíntese, que no inverno representam cerca de $50 \%$ das obtidas no verão (MACHADO, MEDINA E GOMES, 2002).

A necessidade hídrica dos citros, para que se obtenham altos níveis de rendimento, varia de 900 a $1.200 \mathrm{~mm}$ por ano (DOORENBOS E KASSAM, 1979). Sob condições naturais e de alta demanda atmosférica, a transpiração de um pomar adulto de limeira ácida pode chegar a mais de 150 litros por planta por dia nas condições de clima tropical, durante o verão, caindo para cerca de 70 litros por dia, durante os meses de inverno (MARIN, 2000).

Quando os pomares sofrem deficiência hídrica, ocorre queda de flores e dos frutos jovens ou redução do crescimento dos frutos já desenvolvidos, com alteração de sua qualidade por diminuição do teor de suco e da acidez (CRUSE, WIEGAND E SWANSON, 1982). Esse efeito é mais significativo entre o florescimento e a "queda fisiológica", enquanto que na fase de maturação os citros são menos sensíveis ao déficit hídrico.

Segundo a FAO (2008), o Brasil é o quarto produtor mundial de limões, ficando atrás apenas de México, Índia e Argentina. Estima-se uma área plantada em cerca de 48,5 mil ha. Segundo o IBGE, em 2006, São Paulo foi responsável por $80 \%$ da produção brasileira de limeira ácida, seguido da Bahia (3,98 \%), Minas Gerais (3,51 \%) e Rio de Janeiro (3,34\%).

\subsection{Importância da interceptação de radiação solar pelas plantas}

Dentre os vários fatores ambientais que determinam o crescimento e desenvolvimento de plantas, a interceptação da radiação solar pela folhagem é a principal fonte de energia para os processos de fotossíntese, produção de biomassa, balanço de energia, troca de dióxido de carbono e transpiração (MARISCAL et al., 2000; CONSOLI et al., 2006). Dentro de um conjunto de plantas heterogêneas, a distribuição, absorção e atenuação da radiação são geralmente determinadas por uma variação nas condições de incidência da radiação, bem como pela arquitetura e propriedades ópticas da folhagem.

A maneira como a radiação fotossinteticamente ativa é interceptada pelo dossel das plantas é fundamental para a fotossíntese e para a produção das culturas (STEWART et al., 2003). Segundo esses autores, fatores como forma, densidade populacional e espaçamento entre 
linhas, afetam a distribuição da área foliar no dossel das plantas, conseqüentemente interferindo no regime radiativo.

Estudos têm sido realizados para modelagem dos processos hídricos e fisiológicos, principalmente de transpiração em plantas, os quais são de grande importância para estimativas precisas de consumo de água e estimativas de produção das culturas, baseados em dados de radiação interceptada ou absorvida como parâmetro principal. Nutman (1941) já demonstrou a relação existente entre a taxa transpiratória de cafeeiros e a irradiância solar global, fato destacado também em estudos realizados por Gutiérrez e Meinzer (1994) e Marin et al. (2003). Este último estudo mostra ainda uma acentuada relação entre o fluxo de seiva de uma planta e o saldo de radiação do renque de cafeeiros. Resultados semelhantes foram encontrados para macieira, nogueira, videiras e outras espécies lenhosas (THORPE, 1978; GREEN, 1993; VALANCOGNE et al., 2000). O precursor desse tipo de estudos foi Monteith (1965), que ao desenvolver o modelo de Penman-Monteith para estimativa de evapotranspiração, o qual é considerado como padrão até os dias de hoje, também desencadeou outros estudos para estimativa de transpiração em plantas isoladas (BUTLER, 1976; McNAUGHTON et al., 1992; GREEN, 1993).

Desta forma, com o saldo de radiação da folhagem da planta de interesse, e as demais variáveis exigidas pelos modelos de estimativa da transpiração, tem-se a possibilidade de estabelecer relações entre a transpiração da planta e a evapotranspiração de referência, determinando o coeficiente basal de culturas que orientarão no processo de irrigação localizada, pois com a escassez da água aumentando a cada dia, faz-se necessário otimizar a sua utilização, principalmente na agricultura, manejando de forma mais racional os sistemas de irrigação.

\subsection{Medida do saldo de radiação em comunidades vegetais}

A energia radiante interceptada pelas plantas é o fator básico do ambiente envolvido em seus processos físicos e fisiológicos. Devido a sua importância, gera vários estudos teóricos e experimentais sobre a forma de interceptação e aproveitamento da radiação solar, desde como fator principal da fotossíntese e transpiração em plantas até mesmo como fator desencadeante de estádios fenológicos, qualidade de frutos, etc. 
Estudos sobre interceptação de radiação tem sido realizados, principalmente em dosséis horizontalmente homogêneos, quanto à distribuição de plantas no terreno e com folhagem randomicamente distribuída, como pastagens (BROUGHAM, 1958), girassol (LEMEUR, 1973), soja (FONTANA et al.,1991), fava (RIDAO et al., 1996), milho (KUNZ et al., 2007), amendoim (ASSUNÇÃO et al., 2008), entre outras culturas, principalmente pela maior facilidade experimental na sua determinação, já que essas culturas, mesmo cultivadas em linhas, quando atingem seu máximo desenvolvimento de área foliar cobrem totalmente o terreno. Nesse tipo de cobertura, a determinação das trocas verticais de energia radiante entre a superfície vegetada e a atmosfera é suficiente para caracterizar o saldo de radiação (correspondente à energia radiante absorvida) da cobertura vegetal. Para isso, as medidas são feitas com os sensores colocados na horizontal num nível acima da cobertura.

Em pomares e cafezais, por exemplo, com espaçamentos largos, mesmo no estágio adulto somente uma parte do terreno é coberto pela vegetação do terreno. Em plantios adensados nos quais as copas das árvores chegam a se tocar na linha de plantio ("renques") ou podem, em certos casos, com maiores espaçamentos serem consideradas plantas "isoladas". Muitas vezes há interesse em se determinar o saldo de radiação dessas estruturas vegetais específicas (linhas de plantio, árvores isoladas), para aplicação em estudos de transpiração e de fotossíntese. Para tal, é necessário considerar que além das trocas de energia radiante na vertical, há trocas laterais entre as árvores e a atmosfera.

Nas determinações da energia radiante absorvida pela copa das árvores isoladas ou em renques, pode-se dispor de sensores radiométricos posicionados acima e abaixo do dossel vegetativo. Porém, ainda existem poucos trabalhos realizados sobre interceptação de radiação por dosséis descontínuos, com setorização da vegetação, onde se trabalham com plantas isoladas ou trechos de renques. Stanhill, Hofstede e Kalma (1965) realizaram um dos primeiros estudos do balanço de radiação em um dossel agrícola, utilizando um pomar de laranjeira, porém utilizando uma metodologia similar à utilizada para cultivos homogêneos, posicionando um saldoradiômetro com suas placas na horizontal acima do pomar.

No caso de plantas "isoladas", que crescem individualmente, e não sofrem influência da interceptação de radiação pelas plantas vizinhas, Charles Edwards e Thornley (1973) e Warren Wilson (1981), fizeram uma abordagem teórica sobre a forma de interceptação da radiação por este tipo de dossel. No caso da formação de renques, trabalhos como os de Proctor et al. (1972), 
Charles-Edwards e Thorpe (1976), Palmer e Jackson (1977), Palmer (1977) e Palmer (1989), abordam este assunto, tratando sempre da interceptação de radiação pela cultura da macieira.

Um trabalho pioneiro nos estudos de saldo de radiação em renques foi o de Landsberg et al. (1975), que realizaram medidas de saldo de radiação da folhagem de um renque de macieiras na Grã-Bretanha. Foram instalados 8 saldo-radiômetros lineares em torno de uma árvore de macieira, fixados de maneira a ter as placas sensoras orientada ao longo da linha de plantio, compondo um cilindro imaginário em torno da copa, permitindo verificar o padrão diário de variação da radiação por unidade de área foliar. Posteriormente, Thorpe (1978), utilizou-se da mesma técnica para obter o saldo de radiação da copa por unidade de área foliar (Rnf), em macieiras, na Grã-Bretanha, para uso na estimativa da transpiração de macieiras.

A partir da década de 90, essa técnica de determinação de interceptação por dosséis descontínuos sofreu mudanças, de modo a melhorar a amostragem, integrando-se as medida de saldo de radiação no espaço e no tempo. Desta maneira, os equipamentos passaram a ser movimentados ao redor das copas das plantas de interesse, para se minimizar o efeito de heterogeneidade da copa na amostragem proporcionada pela distribuição heterogênea da folhagem. Desta forma, surgiram duas abordagens diferenciadas, mas baseadas no mesmo principio de integração espaço temporal. Em uma delas, desenvolvida para plantas isoladas, o equipamento de medidas proporciona uma geometria esférica ("esfera nocional") de medida para integração dos fluxos de entrada e saída a partir de sua superfície.

O primeiro trabalho com essa técnica foi publicado por McNaughton et al. (1992), que usaram em Palmestorn, Nova Zelândia, um sistema móvel de medidas denominado por eles de “Whirligig” ("pião"), o qual permitia aos sensores de radiação distribuídos latitudinalmente em torno da copa fazer um movimento rotacional no sentido horizontal em torno da copa da árvores. O sistema era composto por oito saldos-radiômetro e 16 quantômetros, fixados em uma armação circular vertical de ferro de $1,85 \mathrm{~m}$ de raio, em intervalos equilatitudinais de $22,5^{\circ}$, visualizando para o interior e exterior da esfera descrita durante um giro do sistema em torno da copa. Cada sensor percorria um caminho circular horizontal cujo raio era dependente da sua posição de montagem. A estrutura circular vertical foi apoiada sobre uma armação circular horizontal de 1,5 $\mathrm{m}$ de diâmetro, permitindo movimento de três rotações por minuto da armação circular vertical em torno da planta. Os 16 sensores quânticos para medida do saldo de densidade de fluxo de fótons fotossintéticos foram posicionados nas mesmas latitudes de montagem dos saldo- 
radiômetros, oito visando o centro da esfera sensora e os demais seu exterior. O equipamento foi montado em torno de uma planta de Robinia pseudoacacia, com 3,8 m de altura e $10,6 \mathrm{~m}^{2}$ de área foliar, e os resultados de saldo de radiação se mostraram consistentes.

Posteriormente o sistema desenvolvido por McNaughton et al. (1992) foi utilizado por Green (1993), em uma nogueira com $26,4 \mathrm{~m}^{2}$ de área foliar. Os dados de saldo de radiação foram incorporados eficientemente no modelo de Penman-Monteith, procedendo-se satisfatoriamente estimativas de transpiração em comparação as taxas volumétricas medidas pelo método de fluxo de seiva. Green et al. (1995) utilizaram esse sistema móvel para verificação do aumento na absorção da radiação fotossinteticamente ativa e saldo de radiação de uma macieira com $35,5 \mathrm{~m}^{2}$ de área foliar.

Angelocci et al. (1999, 2004) desenvolveram em Piracicaba, SP, dois sistemas de integração do saldo de radiação, similares ao proposto por McNaughton et al. (1992), para medidas em limeira ácida adulta. O primeiro equipamento tinha como principal modificação o formato da estrutura da armação circular vertical e o sistema de transmissão de torque. Também houve a redução no número de sensores utilizando apenas seis saldo-radiômetros. A segunda estrutura utilizou oito saldo-radiômetros posicionados nas mesmas latitudes relatadas no trabalho de McNaughton et al. (1992). Utilizou-se novamente uma árvore de limeira ácida "Tahiti", de maior porte que a anterior. $\mathrm{O}$ equipamento apresentou problemas na transmissão de torque, de modo que muitos dias de medida foram perdidos por esse problema. Esse problema de torque foi eliminado em um trabalho posterior em laranjeira (PILAU, 2005; PILAU et al., 2007).

A técnica de medida de interceptação de radiação em renques, formando geometria cilíndrica, foi melhorada e empregada em renques de cafezais e diferentemente dos trabalhos anteriores de Landsberg et al. (1975) e Thorpe (1978), onde a disposição dos radiômetros era fixa, nesses trabalhos utilizou-se um equipamento composto por um arco de medida onde os equipamentos foram fixados, movidos por um sistema de correias e engrenagens, tracionadas por motor elétrico, percorrendo o caminho de varredura sobre um trilho de base fixa.

O sistema de medida em renques utilizado por Landsberg et al. (1975) e por Thorpe (1978) na Inglaterra, formando uma geometria cilíndrica nocional de cálculo, foi modificado em Piracicaba, SP, pelo uso de sensores se movimentando no sentido horizontal ao longo de um trecho de renque de cafeeiros nos sentidos de ida e volta. Marin (2003) utilizou um sistema móvel de medida ao longo de um renque, no qual os saldos-radiômetro foram instalados a 
intervalos de $45^{\circ}$ em um arco circular de alumínio posicionado em torno do renque e deslocandose na direção deste à velocidade aproximada de $12,8 \mathrm{~m} \cdot \mathrm{min}^{-1}$. O mesmo estava apoiado sobre um suporte tracionado por corrente com 4,28 m de comprimento e acionado por um motor elétrico de $0,75 \mathrm{hp}$ com redutor de velocidade. O sistema descrevia um caminho de ida e volta a cada 40 segundos, permitido por um mecanismo de inversão da rotação do motor acionador. O sistema amostrou integralmente a copa de quatro cafeeiros. Os dados de Rn obtidos foram utilizados para se determinar a sua relação com a irradiância solar global e o saldo de radiação de gramado e usado em modelos de evapotranspiração de plantas.

Pilau (2005) e Angelocci et al. (2008) trabalharam em um cafezal em formação, com um sistema móvel de medidas, utilizando oito saldo-radiômetros para compor o cilindro nocional de medidas, que se deslocavam ao longo de cinco plantas (em torno de 4,7m) realizando a varredura em $40 \mathrm{~s}$, tempo este para percorrer o trilho de deslocamento nos dois sentidos (ida e volta). As medidas realizadas de $\mathrm{Rn}$ foram utilizadas para determinar a sua relação com a irradiância solar global e o saldo de radiação de gramado, para testar valores obtidos através do uso de modelo baseado na Lei de Beer, e para adaptar modelos teóricos de estimativa de $\mathrm{Rn}$, descritos na literatura.

Simon et al. (2009), utilizando a metodologia iniciada por Marin (2003), mas com um sistema adaptado para culturas de grande porte, trabalharam com um renque de limeiras ácidas, no qual promoveram a modificação no número de sensores, utilizando 12 sensores para a formação do cilindro de amostragem e encontraram valores de saldo de radiação, convertidos em calor latente, coerentes com valores de evapotranspiração medidos por lisimetria de pesagem.

\subsection{Estimativa do saldo de radiação solar em copas de lenhosas}

Estudos vêm sido desenvolvidos sobre a estimativa da radiação interceptada por plantas, e basicamente existem três tipos de abordagem quando se trabalha com dosséis descontínuos, sejam de plantas "isoladas" ou trechos de renque: a) através da relação entre o saldo de radiação da copa com a irradiância solar global e com o saldo de radiação de gramado; b) utilizando-se a lei de Beer modificada por Monsi e Saeki (1953); c) por modelagem físico-matemática. 


\subsubsection{Relação entre o saldo de radiação de plantas, irradiância solar global e saldo de radiação de gramado}

Utilizando-se de dados obtidos com um sistema móvel de integração do saldo de radiação (Rn), Angelocci e Villa Nova (1999) em uma árvore de limeira ácida "Tahiti”, com 41,6 m² de área foliar, relatam que o $\mathrm{Rn}$ da árvore equivaleu em média ao $\mathrm{Rn}$ de $14,1 \mathrm{~m}^{2}$ de gramado. Entretanto, essa relação não foi constante ao longo do ano, pois no período de dezembro a março correspondeu a $13,5 \mathrm{~m}^{2}$ de gramado e de maio a julho a $17,1 \mathrm{~m}^{2}$ de gramado. Da mesma forma, Angelocci et al. (2001) e Angelocci et al. (2004), relacionaram os dados do saldo de radiação por área de projeção da copa (Rn/PA) de duas árvores de limeira ácida com 39,9 m² e 51,2 m² de área foliar, com os dados de irradiância solar global (Rs), encontrando relações lineares de $R n / A P=$ $0.94 R s$, considerando-se apenas o período diurno, e $R n / A P=0.90 R s$ integrando-se nas 24 horas para uma área foliar de $39,9 \mathrm{~m}^{2}$, e $R n / A P=0.92 R s$ (período diurno) e $R n / A P=0.79 R s$ (24 horas) para uma planta com 51,2 $\mathrm{m}^{2}$ de área foliar.

Trabalho similar realizado por Pilau et al. (2007) em Piracicaba, com laranjeira, com área foliar de $37 \mathrm{~m}^{2}$, e variação de área foliar obtida a partir de desfolhamentos $\left(27,3 \mathrm{~m}^{2}, 18,2 \mathrm{~m}^{2}\right.$, $12,0 \mathrm{~m}^{2}, 0,0 \mathrm{~m}^{2}$ ) mostrou relações variáveis entre $\mathrm{Rn}$ da copa, com o $\mathrm{Rn}$ de gramado e a irradiância solar global, de acordo com a variação da área foliar.

Com os dados de Rn de uma nogueira com $26,4 \mathrm{~m}^{2}$ de área foliar, obtidos por Green (1993) e de uma limeira ácida, com 39,9 $\mathrm{m}^{2}$ de área foliar, Pereira et al. (2001) estabeleceram relações entre o saldo de radiação dessas árvores (Rnf) e o saldo de radiação de gramado (Rng). Os saldos de radiação integrados para as árvores corresponderam ao saldo de radiação de 12,58 $\mathrm{m}^{2}$ (nogueira) e $8,39 \mathrm{~m}^{2}$ (limeira ácida) de gramado. Quando os autores expressaram o Rn por unidade de área foliar, obteve-se a relação única, $\mathrm{Rnf}=0,32 \mathrm{Rng}$.

Marin (2003) determinou o saldo de radiação para um trecho de renque de cafezal adulto, com espaçamento de 2,5 m x 1,0 m, e verificou que correspondia a $49 \%$ da irradiância solar global. Quando relacionado ao saldo de radiação de gramado, a relação encontrada foi próxima de $1: 1$.

Pilau (2005) determinou o saldo de radiação do renque (Rnc) para a mesma área experimental, mas com cafeeiros em diferentes estádios de desenvolvimento. Ele correlacionou os valores obtidos com dados de irradiância solar global $(\mathrm{Rg})$ e saldo de radiação de gramado 
(Rng), obtidos em estação meteorológica próxima. Para cafezais adultos, com área foliar de 4,21 $\mathrm{m}^{2}$, o autor encontrou as seguintes relações na escala diurna: $R n c / A F=0.359 R n g+1.226 \mathrm{e}$ $R n c / A F=0.10 R g+2.02$. Para cafezais em formação, variando-se a área foliar das plantas de $1,42 \mathrm{~m}^{2}$ até $12,61 \mathrm{~m}^{2}$, encontrou em escala horária que $R n / A F$ correspondeu de $11 \%$ a $23 \%$ de Rng e valores de $R n / A F$ que corresponderam de 6 a $11 \%$ de $\mathrm{Rg}$, quando a área foliar diminuiu.

\subsubsection{Estimativa através do uso da Lei de Beer}

Estudos sobre atenuação luminosa iniciaram-se em 1729 com Pierre Bouguer, na área da química, entretanto o modelo matemático somente foi desenvolvido por Johann Heindrich Lambert em 1760. Os pesquisadores estudaram a variação na absorção de um feixe de luz, em função da alteração na espessura da camada absorvente. Mais tarde, em 1852, August Beer fez um experimento análogo, mas relacionado com a concentração do meio (c), mantendo a espessura da camada constante (b). Combinando estas duas leis resultou a chamada Lei de BeerLambert.

Na área de produção vegetal Monsi e Saeki (1953) introduziram a aplicação da Lei de Beer para descrever a extinção luminosa em planta, assumindo que a radiação é extinta exponencialmente no interior do dossel, em função da área foliar e do coeficiente de extinção de radiação solar. A partir deste trabalho muitos pesquisadores têm aplicado as variações deste modelo para estudar o comportamento da radiação solar em comunidades vegetais, conforme as alterações na estrutura da parte aérea das plantas (IAF, orientação e inclinação folhar), no espaçamento e população de plantas (BARTELINK, 1998; DÍAZ-AMBRONA, 1998; LAPPI E STENBERG, 1998).

Além do grande uso em coberturas homogêneas, buscando-se aumento na produtividade, pela melhoria na conformação de plantas e sua distribuição a campo, vários autores tem usado a lei de Beer para estimativa do saldo de radiação de plantas isoladas ou renques de plantas.

Charles-Edwards e Thornley (1973) desenvolveram um modelo simples para interceptação de radiação para uma planta isolada, que tem como suposições: as folhas presentes na copa da planta estão aleatoriamente e uniformemente distribuídas em um volume elíptico, e a radiação que atravessa o meio é atenuada de acordo com a lei de Beer e o espalhamento de energia pode ser negligenciado. Os resultados obtidos mostraram que pode ser usado com boa 
precisão, se aproximando dos testes realizados em laboratório, embora existam ressalvas sobre a necessidade de mais estudos sobre a forma como a energia espalhada interage na planta e sobre como a distribuição da folhagem e o ângulo foliar pode interferir nessa interação.

Esses modelos, inicialmente desenvolvidos para plantas isoladas, passaram a ser utilizados em culturas em renques. Charles-Edwards e Thorpe (1976) adaptaram o modelo de Charles-Edwards e Thornley (1973) para um pomar de macieiras em renque visando o estudo da atenuação da radiação na forma difusa e direta, através da copa das plantas. Para isso consideraram que a densidade do fluxo de radiação que passa através de uma superfície horizontal, em qualquer ponto dentro da cobertura pode ser calculada diretamente. Os autores verificaram que a geometria simulada do renque foi muito semelhante a real, e que os resultados de atenuação de radiação tiveram boa concordância com os valores observados, dando credibilidade ao modelo para estimativa do total de radiação absorvida por um pomar.

Jackson e Palmer (1979) desenvolveram um modelo simples de interceptação de radiação em dosséis descontínuos. O modelo considera a geometria do pomar (espaçamento, distribuição e forma das plantas) e a radiação sendo extinta exponencialmente, de acordo com a lei de Beer. $\mathrm{O}$ modelo foi avaliado frente a medidas obtidas em vários renques de macieiras, no qual se variou o espaçamento entre as linhas de plantio, embora o coeficiente de extinção usado tenha sido fixado em 0,6. O modelo mostrou boa aplicabilidade, além de facilidade na sua aplicação, exigindo poucas variáveis obtidas experimentalmente.

Norman e Welles (1983) descrevem um modelo também utilizado em dosséis com cobertura parcial do solo, assumindo uma geometria elipsóide de renque, por ser uma forma geométrica que pode ser extrapolada para as demais silhuetas. O modelo estudou separadamente o componente direto e difuso e o multi-espalhamento nos comprimentos de onda na região do visível e infravermelho, além de acrescentar uma componente correspondente ao balanço de ondas longas.

Estudos realizados por Marin (2003) em renque de cafeeiros compararam dados de energia radiante absorvida, obtidos experimentalmente por um sistema móvel de medidas e dados obtidos segundo a Lei de Beer. O coeficiente de extinção para uso da Lei de Beer foi determinado por medidas com saldos-radiômetro instalados acima e abaixo da copa, nos quais se obteve valores que variaram de 0,2 a 0,95, com valor médio diário fixo de 0,49. Dados obtidos por meio da aplicação da lei de Beer superestimaram em 9\% na média, os dados medidos diretamente no 
renque. Segundo o autor, a aplicabilidade é viável nos casos em que se determina experimentalmente o coeficiente de extinção luminosa e o índice de área foliar do renque estudado, pois a obtenção de medidas de energia radiante abaixo e acima do dossel é mais simples que o uso de equipamentos para medida direta da radiação absorvida.

Annandale et al. (2004) desenvolveram um modelo bidimensional de interceptação de radiação por renques de árvores frutíferas. $\mathrm{O}$ mesmo foi baseado nos modelos propostos por Charles-Edwards e Thornley (1973) e Charles-Edwards e Thorpe (1976) e assume que as folhas são uniformemente distribuídas dentro de um elipsóide e a radiação que penetra no dossel é atenuada conforme a lei de Beer. Além disso, o modelo considera além do renque estudado, os dois renques vizinhos e faz um desmembramento da irradiância solar global, em difusa e direta, nos comprimentos de onda de radiação fotossinteticamente ativa (PAR) e do infravermelho próximo (NIR). Os autores utilizaram o método proposto por Weiss e Norman (1985) para estimar a componente direta e difusa, para as bandas de PAR e do NIR a partir da irradiância solar global. A validação do modelo foi realizada em vários pomares, na qual se teve uma variação distinta entre orientações de renque, densidade de plantas, altura e geometria de plantas e área foliar, e ainda plantas caducifólias e "sempre verdes". Os dados de radiação transmitida nos pomares foram obtidos pela diferença entre os valores observados no topo da cultura, através de piranômetros da marca LI 200X instalados nas estações meteorológicas automáticas em áreas com horizonte aberto, próximas ao experimento e valores médios de sete tubo-solarímetros Delta-T instalados eqüidistantes abaixo da cobertura, posicionados desde a linha de plantio até a metade das entrelinhas subjacentes. Os resultados mostraram que nas condições em que se tem um renque uniforme e elíptico, com uma distribuição uniforme da folhagem, o modelo prevê excepcionalmente bem o ciclo diário da radiação transmitida, mas em condições onde o dossel não apresenta simetria ou há desuniformidade na distribuição da folhagem, ocorrem erros elevados, chegando a $40 \%$ com relação aos valores diários observados.

Pilau (2005) determinou o saldo de radiação do renque (Rnc) para uma área experimental com cafeeiros, na qual o autor modificou as áreas foliares devido a sucessivas desfolhas $\left(12,61 \mathrm{~m}^{2}\right.$ até 1,42 $\mathrm{m}^{2}$ ). Ele correlacionou os valores observados com os valores estimados utilizando a lei de Beer para o período diurno (6 às 18h) em todas as áreas foliares e encontrou uma subestimativa de $8 \%$. 


\subsubsection{Estimativa do saldo de radiação por modelagem física-matemática}

Tanto as medidas pontuais de interceptação de radiação, como as realizadas pelos sistemas móveis de integração do saldo de radiação, são utilizadas para a aferição de modelos físico-matemáticos, criados para estimar a interceptação da radiação por espécies arbóreas.

A modelagem físico-matemática geralmente envolve correlações mais complexas, as quais levam em consideração um maior número de variáveis atuando sobre o sistema, como: dimensões do pomar, forma e dimensões do renque e/ou das plantas, sua orientação, radiação solar e, em alguns casos, suas componentes direta e difusa, densidade foliar ou porosidade do dossel e também seu poder de reflexão, entre outras, como verificado, por exemplo, nos modelos de interceptação de radiação desenvolvidos para videira por Riou, Valancogne e Pieri (1989), e para macieiras por Palmer (1989) e Green et al. (2003).

Uma das primeiras tentativas em se modelar matematicamente a interceptação de radiação por plantas isoladas ou renques foi realizada por Charles-Edwards e Thorpe (1976) que testaram a aplicabilidade de um modelo empírico desenvolvido por Charles-Edwards e Thornley (1973) na interceptação de radiação por renques de macieiras, simulando perfis de transmissão de radiação. Os dados simulados foram próximos aos medidos experimentalmente, e as variações sazonais que ocorreram na interceptação da radiação foram similares àquelas encontradas por Allen (1974) em renques de conformação retangular. Os mesmos autores verificaram que renques orientados no sentido leste-oeste absorveram $13 \%$ menos radiação direta do que àqueles posicionados no sentido norte-sul para o solstício de verão no hemisfério norte, sendo a radiação difusa independente da orientação do renque.

Palmer (1977) descreve um modelo matemático modificado para macieira, baseado num trabalho anteriormente desenvolvido por Jackson e Palmer (1972), onde a principal suposição é que o renque possua comprimento infinito e silhueta triangular. $\mathrm{O}$ modelo assume que as estruturas da planta estão distribuídas de forma homogênea dentro do volume de renque e a atenuação é uma função logarítmica para cada estrutura em particular (caule, folhas, frutos), desconsiderando a interação entre ambas. Os dados gerados pelo modelo apresentaram uma boa concordância com os dados medidos de radiação direta e difusa. O mesmo autor utilizou-se de seu modelo para estudos de interceptação e distribuição de radiação no renque (PALMER, 1989). Para isso ele utilizou-se de pomares em diferentes latitudes e orientações de plantio, com alturas 
de plantas e espaçamento entre renques diferenciados, e nas diferentes épocas do ano. Os resultados mostraram que a variação da interceptação em função da orientação das linhas de plantio não é única, mas também sofre influência do espaçamento, época do ano e altura de plantas, o que mostra uma grande complexidade no estudo da interceptação radiação em renques, neste caso, de macieiras. Esse tipo de estudo é de fundamental importância para se definir novas técnicas de manejo e influenciar os melhoristas de plantas para buscarem cultivares que apresentem um desempenho satisfatório.

Riou, Valancogne e Pieri (1989) desenvolveram um modelo de interceptação de radiação para a cultura da videira, manejada sob espaldeira, na qual assumem que o renque apresenta geometria em forma de paralelepípedo, e que sua relação com o movimento solar permite a estimativa da interceptação solar pelo renque. Para isso, eles consideram a porosidade do renque, as orientações de renque e do sol, e que a radiação que intercepta o renque é composta por uma fração direta e uma fração difusa. Os valores experimentais obtidos a campo, quando comparados aos valores obtidos pelo modelo, confirmaram a eficiência do modelo em estimar a energia interceptada pela videira, pois apresentaram uma alta concordância nos dados.

$\mathrm{Na}$ busca por um modelo que apresentasse bons resultados para diferentes estruturas de cobertura, variando de plantas individuais até coberturas homogêneas, Röhrig, Stützel e Alt (1999) desenvolveram um modelo tridimensional para estudar o caminho percorrido pela radiação dentro de um dossel. O modelo deveria fornecer informações detalhadas sobre a absorção da radiação nesses dosséis, seguindo rotinas simples e facilmente adaptáveis para outros estudos. O volume total do renque é subdividido em cubos, os quais podem conter ou não estruturas da planta. A energia transmitida através do cubo é calculada em função da trajetória dos raios solares a partir da extremidade superior do dossel até o nível do solo. O cálculo é feito para radiação direta e difusa separadamente, considerando a reflexão e o espalhamento do feixe. Os dados provenientes do modelo foram confrontados com dados obtidos a campo, analisando o efeito de diferentes arquiteturas de plantas na absorção de energia, e os resultados mostraram confiáveis para a transmissividade da energia solar.

Melo-Abreu, Snyder e Ribeiro (2002) desenvolveram um modelo que trabalha diferenciando as fontes em radiação direta e difusa, sendo as mesmas integradas a qualquer momento e em qualquer ponto de uma reta que simula o caminho percorrido pelo feixe radioativo, desde o topo do renque até sua base. O modelo foi validado com dados de um pomar 
de macieira, alcançando resultados satisfatórios, e com isso, tornando-o apto a constituir modelos mais complexos, que utilizem dados de interceptação de radiação como um módulo de cálculo para obtenção de produção, crescimento, ou até mesmo consumo hídrico.

Um modelo tridimensional e de maior complexidade foi desenvolvido por Green et al. (2003), baseado em suposições e modelos desenvolvidos anteriormente, como na teoria de cálculo, adaptada de Norman e Welles (1983) e Wang e Jarvis (1990), e na suposição de que, excetuando-se as folhas, as demais estruturas da planta absorvem menos de $5 \%$ de radiação do total absorvido, e a influência dessas estruturas pode ser negligenciada (PALMER, 1977). O modelo considera que a planta apresenta uma forma semelhante a um elipsóide, e que as folhas estão distribuídas randomicamente dentro do volume de controle. Além disso, a estrutura tridimensional do modelo permite se trabalhar com três dimensões dentro do volume de controle, o que permite uma maior confiabilidade frente aos modelos unidirecionais, e também, permite o estudo do efeito de interceptação de radiação quando se varia o padrão do plantio do pomar. As componentes radioativas do modelo, radiação direta e difusa, foram estimadas a partir de medidas de radiação presentes no pomar e a absorção foi calculada em função de comprimentos de ondas, pois as propriedades óticas das folhas (transmissão, reflexão e absorção) dependem desse comprimento.

Pilau (2005) adaptou o modelo desenvolvido por Riou, Valancogne e Pieri (1989) para a cultura do cafeeiro, e fez a sua validação a partir de determinação direta, obtida por um sistema integrador espaço-temporal de medidas do saldo de radiação movimentando-se ao longo da linha de plantio, formando uma geometria cilíndrica, com amostragem de quatro plantas. Também foi desenvolvido um modelo para plantas isoladas, aplicado em um pomar de laranjeiras, no qual o equipamento utilizado para obtenção das medidas integrou as medidas em uma esfera nocional. Ambos, os modelos utilizaram dados referentes à orientação solar, a posição de renques, e também referentes à estrutura do renque e da planta. Os modelos consideram o estudo da radiação direta e difusa de forma distinta, sendo possível explicitar a contribuição da radiação absorvida pelo topo e pelas áreas laterais do renque. Os dados medidos pelo sistema integrador, além de utilizados na aferição dos modelos, foram utilizados para estudar-se a aplicabilidade da lei de Beer para dosséis descontínuos, já que a premissa básica dessa lei é que a atenuação do feixe de radiação depende da concentração ou densidade de folhas e da largura desse volume, o qual o feixe percorre desde o topo até a base do renque. Além disso, os dados medidos foram 
usados em relações com a irradiância solar global e o saldo de radiação de gramado. Os resultados encontrados pelos modelos tiveram bom ajuste com os dados medidos, além de demonstrar a aplicabilidade do modelo para vários níveis de porosidade e área foliar de plantas.

Oyarzun (2005) desenvolveu um modelo que considera a planta como um corpo poroso de forma prismática. A radiação solar interceptada pelo pomar é obtida pela relação geométrica entre a estrutura do renque, a posição do sol e o comprimento da sombra formada pelas árvores. O modelo baseia-se na diferenciação entre radiação direta e difusa, e em frações de energia interceptada pela cobertura. Os dados estimados pelo modelo foram comparados aos medidos no pomar na escala horária e diurna. A quantidade de radiação interceptada pelo renque foi obtida pela diferença entre os valores de radiação observados em uma estação meteorológica automática e valores médios medidos por tubo-solarímetros (AccuPAR, Decagon Equipamentos Inc., WA, USA) instalados $30 \mathrm{~cm}$ acima do solo, e movimentados paralelamente a linha de plantio até a metade das entrelinhas subjacentes. Em ambos os casos, a relação foi muito boa, ocorrendo uma melhora do desempenho do modelo quando se trabalhou com os dados na escala diurna. $\mathrm{O}$ modelo mostrou-se prático, com aplicabilidade em uma grande gama de espécies frutíferas, diferentes configurações de pomar e condições ambientais variáveis, além disso, necessita de dados que são facilmente obtidos em nível de campo. O autor cita que o modelo pode ser usado para a escolha da orientação do plantio, melhorando a interceptação ao longo de todo o ano, e também que o modelo pode ser incorporado em modelos mais complexos de fotossíntese, produtividade e eficiência do uso de água como um auxiliar para melhora de desempenho. 


\section{MATERIAL E MÉTODOS}

\subsection{Descrição da área experimental}

O trabalho foi desenvolvido em áreas experimentais do Campus "Luiz de Queiroz", Universidade de São Paulo (USP), município de Piracicaba, SP, nas seguintes coordenadas geográficas: $22^{\circ} 42^{\prime} \mathrm{S} ; 4^{\circ} 30^{\prime} \mathrm{W}$ e $546 \mathrm{~m}$ de altitude e $22^{\circ} 42^{\prime} \mathrm{S} ; 47^{\circ} 38^{\prime} \mathrm{W}$ e $511 \mathrm{~m}$ de altitude, respectivamente para duas áreas em estudo, um cafezal adulto e um pomar de limeira ácida Tahiti (Figura 1a e 1b).
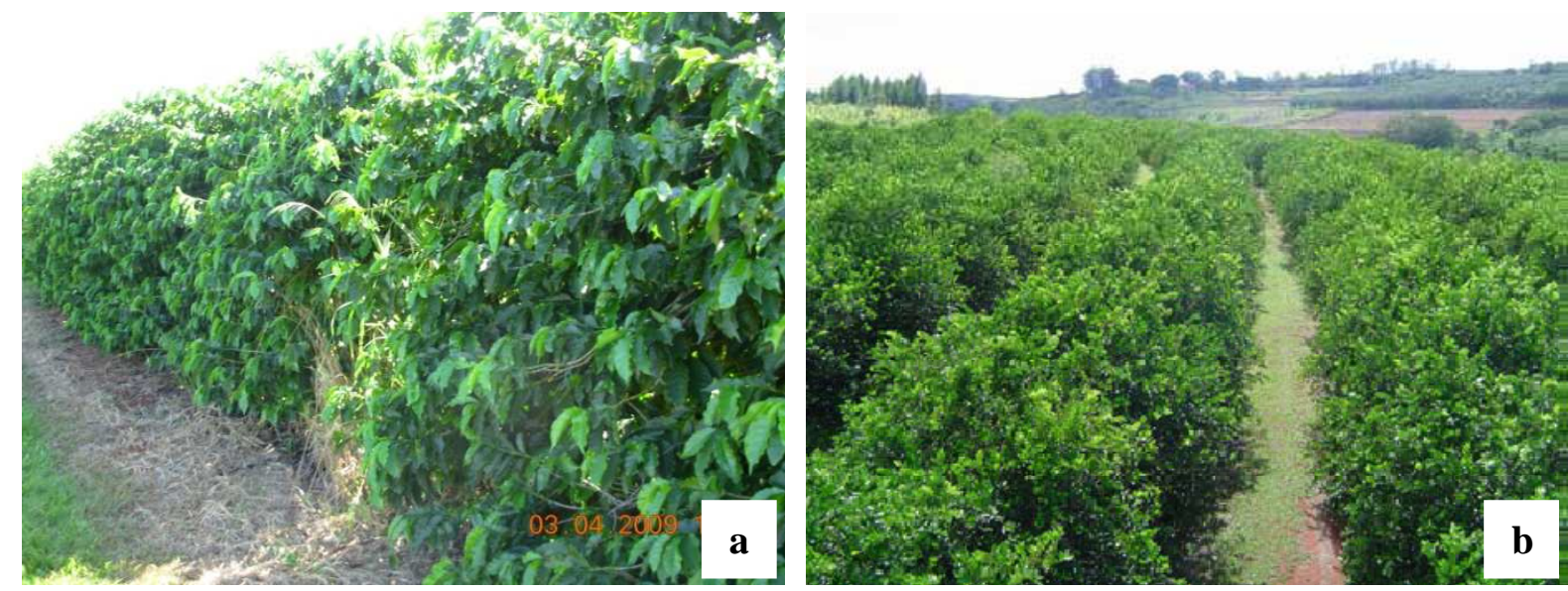

Figura 1 - Detalhe das áreas experimentais utilizadas, cafezal (a) e pomar de limeira ácida (b)

O cafezal foi implantado em outubro de 2001 em uma área de aproximadamente 3,2 ha e na época deste estudo era constituído por plantas adultas da variedade Obatã IAC 1669-20 em pé franco, ao redor de 7 anos, formando renques com altura média de 2,0 m e largura de $1,7 \mathrm{~m} \mathrm{e}$ orientação no sentido NW-SE, com azimute igual a 152 56 'S. O espaçamento de plantio é de 3,5 $\mathrm{m} \times 0,9 \mathrm{~m}$ e a silhueta formada pela folhagem se aproxima da forma de um paralelepípedo. $\mathrm{O}$ trecho do renque escolhido para este estudo estava centralizado na área, representativo das plantas do cafezal, sem falhas na linha e nas suas adjacentes. O estudo prolongou-se de março de 2008 a fevereiro de 2009.

O pomar de limeira ácida [Citrus latifolia (Yu.Tanaka) Tanaka cv. IAC 5], enxertada em citrumelo 'Swingle' [Poncirus trifoliata (L.) Raf. $\times$ Citrus paradisi Macf.] foi implantado numa área de aproximadamente 1,0 ha no ano de 2001, sendo constituído por plantas com 7 anos de idade e espaçadas de 7,0 m x 4,0 m e altura média de 4,5 m, orientadas no sentido E-W, e com 
azimute de renque de $91^{\circ} 07^{\prime} \mathrm{S}$. O trecho escolhido para o estudo foi numa posição central do talhão, com plantas sadias, de porte representativo do pomar e sem falhas no renque e seus adjacentes.

Ambas as áreas tiveram suas entrelinhas manejadas através de roçadas, nas quais a vegetação rasteira era pouco densa e cobria parcialmente a entrelinha e, além disso, sofreram o manejo (adubação, podas, controle de pragas e doenças, etc.) conforme a recomendação técnica para cada cultura.

\subsection{Medidas Biométricas}

A área foliar $(A F)$ foi determinada por dois procedimentos, um direto baseado na extração e contagem de folhas das plantas e um indireto utilizando-se um medidor portátil de IAF (LAI2000 Canopy Analyser, Li-Cor, Lincoln, NE, USA).

No experimento do cafezal, foram realizadas 4 determinações de área foliar, uma em cada estação do ano, coincidentes com a obtenção dos dados de radiação. Todas as determinações foram diretas sendo que na última utilizou-se, conjuntamente, a medida através do LAI-2000 para testar a eficiência do aparelho em obter a área foliar representativa do trecho de renque estudado. Nas determinações diretas foram coletadas todas as folhas de uma planta representativa do cafezal, as quais foram contadas para obter-se o número total de folhas $(n)$ e mediu-se o comprimento $(C)$ e largura $(L)$ de aproximadamente 250 folhas tomadas aleatoriamente para a determinação da área média de folha. O cálculo da área foliar total da árvore foi obtido pela equação, $A F=$ C.L.n.f, sendo $f$ o coeficiente de conversão igual a 0,7 para ajuste da área foliar, determinado por Marin (2003) para um cafezal adulto.

No pomar de limeira ácida foram realizadas apenas duas determinações de área foliar devido a dificuldade de sua obtenção pelo método direto. A primeira determinação foi realizada indiretamente utilizando-se o LAI-2000 pelo qual foi obtido o Índice de Área Foliar (IAF), e posterior a conversão deste índice para área foliar total da planta, utilizando como base para o cálculo a área projetada da copa sobre o terreno. A segunda determinação foi ao final do experimento, de forma direta, retirando-se todas as folhas das plantas envolvidas na obtenção dos dados de radiação. O mesmo procedimento aplicado para o cafezal foi utilizado, baseando-se na 
equação citada anteriormente, e com fator de conversão de 0,7 para limeira ácida, determinado por Marin (2000).

Para a determinação da porosidade média do dossel foram tomadas várias fotografias digitais do renque estudado, das paredes laterais e superiores, com um tecido branco de fundo que homogeneizou o plano de fundo das imagens. Posteriormente, as imagens foram analisadas pelo programa Quant2000, desenvolvido pela Universidade Federal de Viçosa, no qual as imagens foram trabalhadas e obteve-se a área livre dentro da copa do dossel e posteriormente com a média de todas as imagens, a porosidade média do dossel.

Além destas, outras medidas foram realizadas para suprir a entrada dos modelos estudados para determinação do saldo de radiação em renques. Foram realizadas medidas de altura de plantas $(H)$, altura de inserção dos galhos no tronco $(B)$, largura perpendicular a linha do renque $(L r)$ e largura de plantas na linha $(L l)$, todas para delineamento das "faces" receptoras de radiação pelo renque.

Para a determinação da refletividade de radiação pelas folhas das plantas ("albedo") foi utilizado um piranômetro de termopilha marca Kipp-Zonen, modelo CM3, montado de forma invertida, no topo do arco, confrontando as plantas na linha de plantio, sem receber radiação direta advinda da abóboda celeste.

\subsection{Descrições dos sistemas integradores do saldo de radiação de trechos de renque}

Para o cafezal foi utilizado um sistema integrador já instalado no local (MARIN, 2003; PILAU, 2005) e para o pomar de limeiras ácidas foi montado um sistema especificamente desenhado para o estudo. O sistema movimentava 8 e 12 saldo-radiômetros no sentido da linha de plantio no cafezal e no pomar, respectivamente. Os saldo-radiômetros eram do modelo Q7.1 (REBS, Logan, Utah), distribuídos de forma equilatitudinal em torno da copa das plantas de $45^{\circ}$ no cafezal e $30^{\circ}$ no pomar (Figura 2), de forma que suas placas sensoras tangenciassem uma superfície hipoteticamente curvilinear em torno da copa das árvores.

A movimentação desses saldo-radiômetros no sentido da linha gera uma geometria de integração, espacialmente cilíndrica, no tempo de amostragem. Cada sensor amostra os fluxos de entrada e de saída das radiações de ondas curtas e de ondas longas, considerando-os positivos os fluxos de entrada e negativos os de saída no cilindro nocional. A equação de integração é: 


$$
R n_{r}=\left(\frac{1}{n} \sum_{i=n}^{n} R n_{i}\right) d_{h} \cdot 2 \cdot R \cdot \pi
$$

onde $\mathrm{Rn}_{\mathrm{r}}$ é o saldo de radiação integrado das copas das árvores amostradas na distância horizontal $\mathrm{d}_{\mathrm{h}}$ percorrida pelos sensores na linha de plantio, $\mathrm{n}$ é o número de sensores usados, $\mathrm{Rn}_{\mathrm{i}}$ é o saldo de radiação de cada saldo-radiômetro e $\mathrm{R}$ é o raio da base do cilindro nocional, cujo círculo passa pelo centro das placas dos sensores.
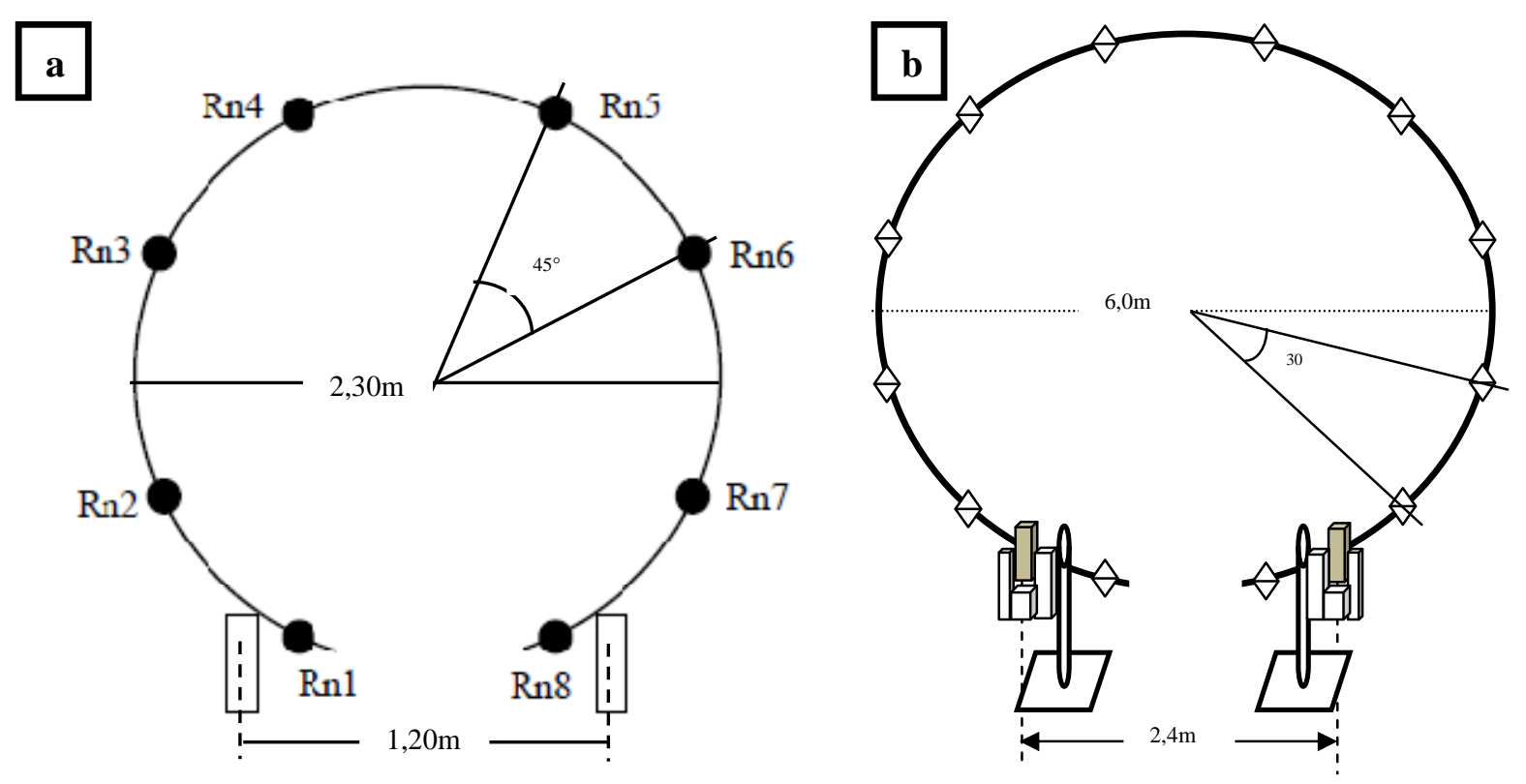

Figura 2 - Esquema de distribuição equilatitudinal dos saldo-radiômetros em torno da copa dos cafeeiros (a) e das limeiras ácidas (b). Fonte Figura 2a: Pilau (2005)

$\mathrm{O}$ valor de $\mathrm{R} \mathrm{n}_{\mathrm{c}}$ medido representa, então, o total de radiação absorvida pelos elementos vegetativos da copa, sendo expresso em joule (ou um valor múltiplo) por unidade de tempo de amostragem, para todo o trecho de linha percorrido, podendo ser expresso, também, em energia por unidade de tempo e de comprimento do renque. A distância $d_{h}$ percorrida pelos sensores foi de 4,4 m no cafezal (amostragem de 5 plantas) e de 16,0 $\mathrm{m}$ (amostragem de 4 plantas) no pomar. Os raios da base do cilindro nocional de medidas tinham dimensões de 1,15 m no cafezal e de 3,0 m no pomar. A partir de 05 de fevereiro de 2009, a planta de uma das extremidades do trecho amostrado no pomar iniciou um processo de perda total das folhas por ocorrência de "greening" 
que a levou à morte, de modo que o sistema foi modificado para que a varredura dos sensores ocorresse somente nas três plantas restantes, ou seja, em 12,0 m.

Além das diferentes dimensões e números de saldo-radiômetros, os dois sistemas apresentavam algumas diferenças mecânicas, tanto de construção como de mecanismo de movimentação dos sensores. Ambos eram constituídos por um arco vertical de fixação dos sensores, arco este preso a uma base móvel que se deslocava sobre dois trilhos separados por barrotes transversais que permitiam mantê-los com espaçamento entre si de 1,20 m no cafezal e 2,40 m no pomar. No cafezal, o arco foi construído por um único tubo metálico com diâmetro interno de 2" (Figura 3). No pomar, devido às suas dimensões (raio de 3,0 m), o sistema em forma de arco de fixação dos sensores teve de ser mais reforçado, sendo constituído por três arcos paralelos construídos em tubos de ferro de diâmetros internos de $100 \mathrm{~mm}$ e de $50 \mathrm{~mm}$, sendo maior, o mais interno (no qual os saldo-radiômetros ficaram fixados) e os externos de $50 \mathrm{~mm}$. Tais arcos foram ligados por um sistema de treliças, que os mantinha unidos e aumentava a resistência de todo o sistema (Figura 4a).

O deslocamento da base de suporte do arco portador dos sensores foi proporcionado por sistemas de correntes, uma única delas no cafezal e por um sistema de engrenagens duplas (uma em cada trilho) no pomar, sendo as correntes tracionadas por motores elétricos monofásicos de 1/3 hp na primeira cultura e $1 \mathrm{hp}$ na segunda, com redutores de velocidade de acordo com o decidido para cada sistema. Em cada extremidade dos trilhos, após a montagem dos sistemas no local definitivo de medidas, foram acopladas estruturas com polias dentadas para promover o deslocamento das correias de tração (Figura 5a).

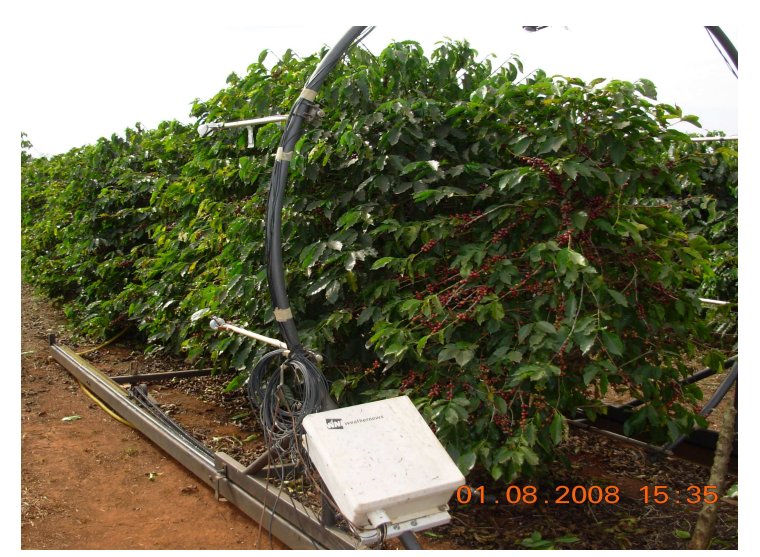

Figura 3 - Vista do sistema de medida no cafezal, com o arco sustentando saldo-radiômetros, trilho e sistema de tração e o sistema coletor de dados ("datalogger”) solidário 

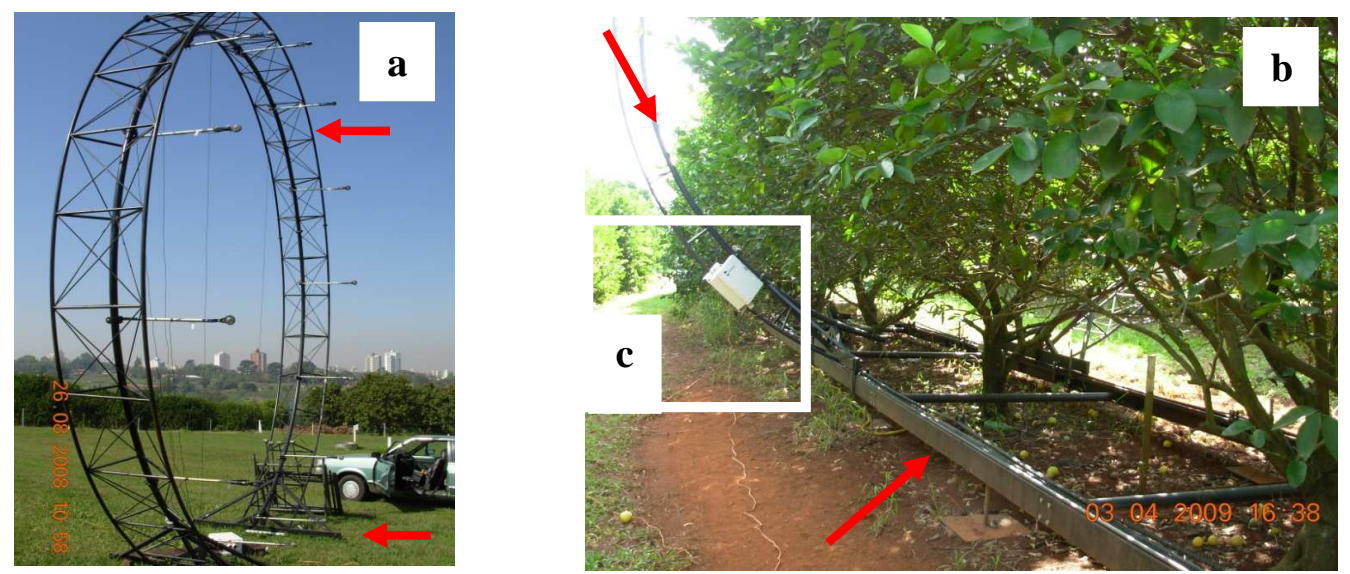

Figura 4 - Vista do arco com os saldo-radiômetros antes de sua instalação na linha de plantio, posicionado para aferições em local com horizonte amplo (a); sistema montado na linha de plantio de limeira ácida, composto do trilho e arco (b) e detalhe de um sistema aquisitor de dados (c). As setas vermelhas indicam detalhes da treliça, base do arco, arco e do trilho
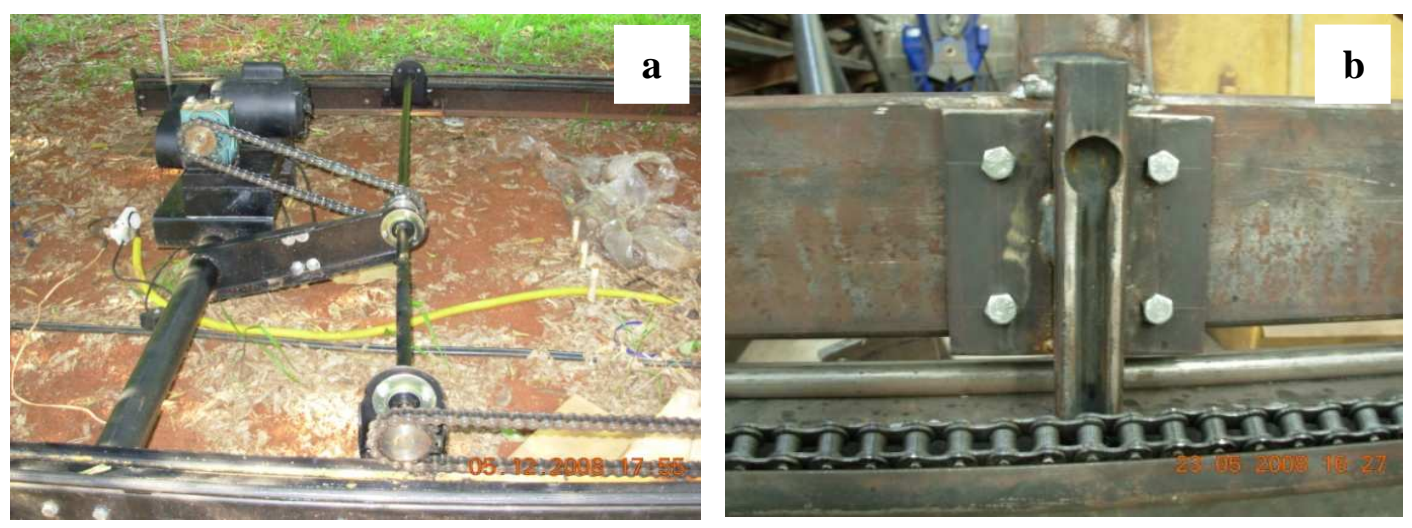

Figura 5 - Vista do sistema de polias de tração e motor elétrico acoplado ao redutor de velocidade (a); vista frontal do sistema de engate para deslocamento do sistema sobre os trilhos (b). Pomar de limeira ácida, Piracicaba, SP

Concluído o percurso do arco e sensores em um determinado sentido, era feita uma reversão automática do sentido de seu deslocamento pelo uso de um sistema mecânico que pode ser visto na Figura 6 para o caso do cafeeiro (PILAU, 2005). Nesse caso, tal mecanismo de reversão do movimento estava fixado em uma das extremidades da base móvel solidária ao arco vertical com os sensores, sendo constituído de uma pequena placa metálica retangular vazada e mantida na vertical, dentro da qual foi colocada outra pequena placa metálica móvel com dois parafusos a ela fixados por uma das extremidades, os quais a transpassavam no sentido horizontal e tinham, cada um, sua outra extremidade fixada na corrente em pontos dos quais foram retirados pinos de união dos seus elos. Com o deslocamento da corrente, a placa móvel com os dois 
parafusos se movimentava e permitia a reversão do movimento. O mesmo mecanismo foi usado no pomar, com a diferença de que o sistema de reversão ficou fixado no centro da base metálica sustentadora do arco e não na extremidade (Figura 5b).

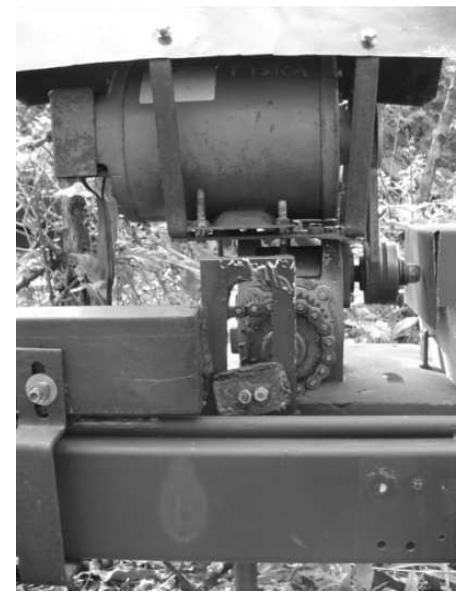

(a)

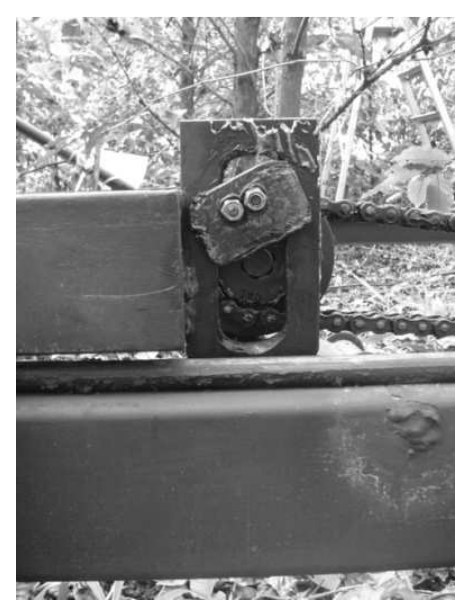

(d)

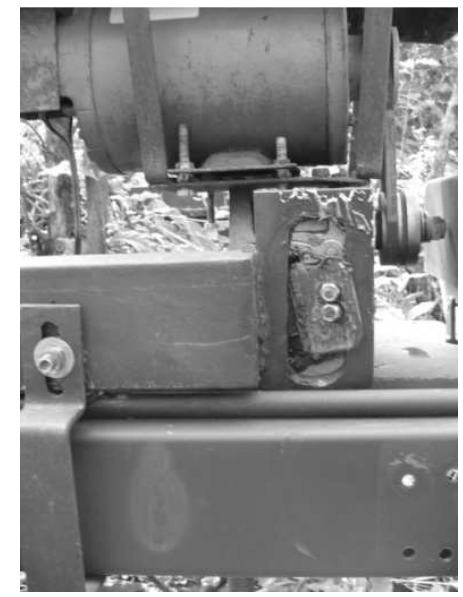

(b)

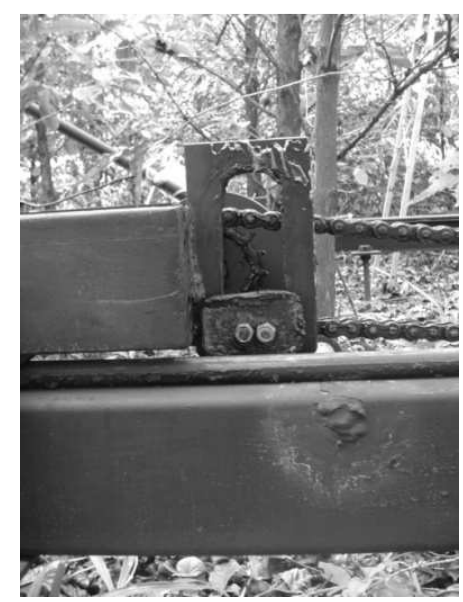

(e)

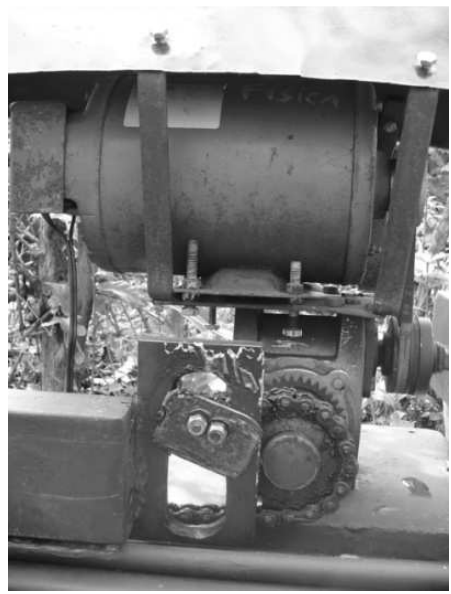

(c)

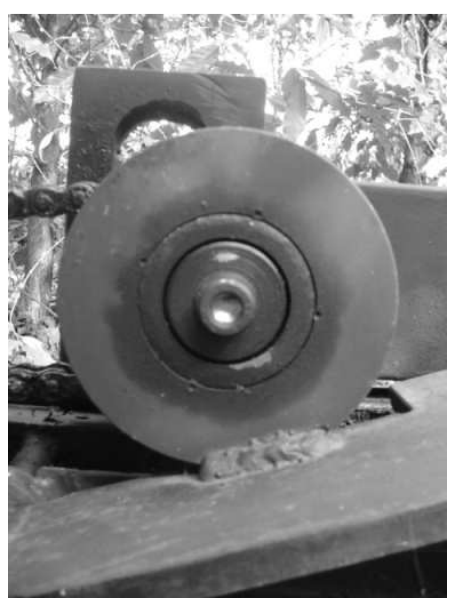

(f)

Figura 6 - Mecanismo de reversão do movimento dos saldo-radiômetros no sentido da linha de plantio no cafezal. Vê-se o motor com o sistema de redução de velocidade e a polia dentada sobre a qual foi acoplada a corrente, vendo-se, também o sistema reversor na extremidade da base portadora do arco vertical (a), (b) e (c). As figuras de (a) até (e) permite visualizar a seqüência do movimento da placa metálica com os parafusos fazendo o movimento que permite a inversão, sendo que em (d) e (e) a inversão está ocorrendo na extremidade oposta ao motor. Em (f) visualiza-se o rolamento. Fonte: Pilau (2005)

Um trajeto de ida e volta era cumprido em 40s no cafezal e no pomar em 80s. Após a aferição de calibração e posicionamento dos saldo-radiômetros no arco (item 3.4), o arco foi levado até o local das medidas no interior de cada cultura. Para a escolha do local levou-se em consideração a representatividade do trecho de renque em termos médios no pomar, a falta de 
falhas de plantas nas adjacências e, no caso do pomar, também a distribuição dos tratamentos de irrigação que eram feitos em outro estudo. Recorde-se que a partir de certa data houve perda de uma planta na extremidade do trecho amostrado no pomar. Posteriormente, outra limeira localizada lateralmente ao trecho estudado, na linha de bordadura apresentou, também, sintomas de "greening", quando se decidiu encerrar o experimento. A instalação dos trilhos envolveu seu nivelamento, conseguido pela existência de bases de suporte com barras verticais de ferro com rosca, que permitiam movimento vertical e a regulagem em altura dos trilhos, além de servirem de suporte para toda a estrutura.

A coleta de dados foi feita com freqüência de $1 \mathrm{~Hz}$ e as médias foram tiradas e armazenadas pelos coletores de dados (“dataloggers") a cada 15 minutos. Foram utilizados coletores Campbell modelo CR 1000 em ambas as coberturas vegetais, sendo que um segundo coletor da mesma marca, modelo CR10 também foi usado no pomar.

\subsection{Aferição e testes de posicionamento dos saldo-radiômetros}

Inicialmente, todos os saldos-radiômetro foram nivelados lado a lado sobre uma superfície homogênea (gramado ou piso de concreto) e aferidos contra um saldo-radiômetro recém adquirido e ainda sem uso, sendo definidas as constantes de calibragem tendo como referência a constante de calibragem fornecida pelo fabricante do sensor tomado como referência (Figura 7a). Definidas as novas constantes, os saldo-radiômetros foram modificados pela introdução de duas placas metálicas, munidas de um parafuso em sua extremidade, que serviram para o nivelamento, posicionamento e contenção das placas sensoras para que as mesmas não se movessem com o movimento de todo o sistema de medida. As constantes, embora determinadas com as placas sensoras na horizontal, podem ser consideradas como válidas para qualquer ângulo de nivelamento delas, segundo McNaughton et al. (1992).

Foram realizados testes anteriores à montagem dos sistemas nas linhas de plantio, para verificar o efeito de sombreamento do arco sobre os sensores e, também, da direção do eixo do arco sobre as medidas, considerando-se os pontos cardeais. Para o cafezal, foram feitos testes considerando as direções N-S e E-W. Como nessa cobertura não foi verificada diferença significativa de efeito entre as duas direções, para o arco do pomar o teste foi realizado somente posicionando-o na direção do renque. 
Para o posicionamento adequado dos saldo-radiômetros, ou seja, se ao serem fixados no arco os dois saldo-radiômetros opostos tinham suas placas sensoras corretamente faceadas, foram realizadas medidas anteriores a sua instalação, sem plantas no interior do sistema. Nessa situação, as leituras dos sensores pareados devem tender a zero (balanço de nulo). Para isso, o nível de bolha que indica o nivelamento da placa sensora no plano horizontal foi usado como referência, para que nenhum sensor realizasse a medida em escala inversa, sendo colocado sempre para a superfície externa do circulo. Para o posicionamento dos pares de sensores, cada um faceado com seu correspondente par, foi desenvolvido um sistema que facilitasse essa determinação a distância, devido as distâncias que eles estavam posicionados, de um observador postado no solo. O sistema de alinhamento das placas dos sensores foi montado com uso de duas luvas de PVC de $40 \mathrm{~mm}$ de diâmetro, em cada uma das quais foi rosqueado um tampão. Cada tampão foi posicionado numa extremidade das luvas sendo que o primeiro tinha um orifício de $5 \mathrm{~mm}$ de diâmetro em seu centro, para servir como alvo, e o segundo um orifício de diâmetro no qual foi fixado um apontador a laser orientado perpendicularmente a superfície plana do tampão (Figura 7b). Desta forma, uma das peças servia como emissor de um feixe de luz e a outra peça com a extremidade vazada era encaixada de forma ajustada sobre a cúpula de proteção dos saldoradiômetros para agir como receptor. No procedimento de ajuste, cada peça era colocada sobre cada saldo-radiômetro do par de opostos e, com auxílio do feixe de luz, eles eram posicionados um face ao outro, quando a luz emitida a partir do laser instalado na peça ajustada em um radiômetro atingia o centro da cúpula do radiômetro oposto. Terminado esse procedimento, a posição correta de cada saldo-radiômetro no arco ficava indicada com ranhuras no próprio arco, de modo que os sensores podiam ser retirados do arco e posteriormente fixados novamente tomando-se esta marca como referência.

No cafezal, a metodologia foi semelhante, mas pelo fato do arco ser bem menor, a instalação dos sensores e seu posicionamento foram mais fáceis e rápidos, e foram distribuídos apenas oito radiômetros para serem confrontados em quatro pares.

Após os procedimentos acima descritos, os sensores foram desmontados do arco, o qual foi então montado sobre o restante do sistema (trilho e sistema de movimentação) e os sensores foram novamente fixados no arco na posição anteriormente determinada, já prontos para as medidas na linha de plantio. 

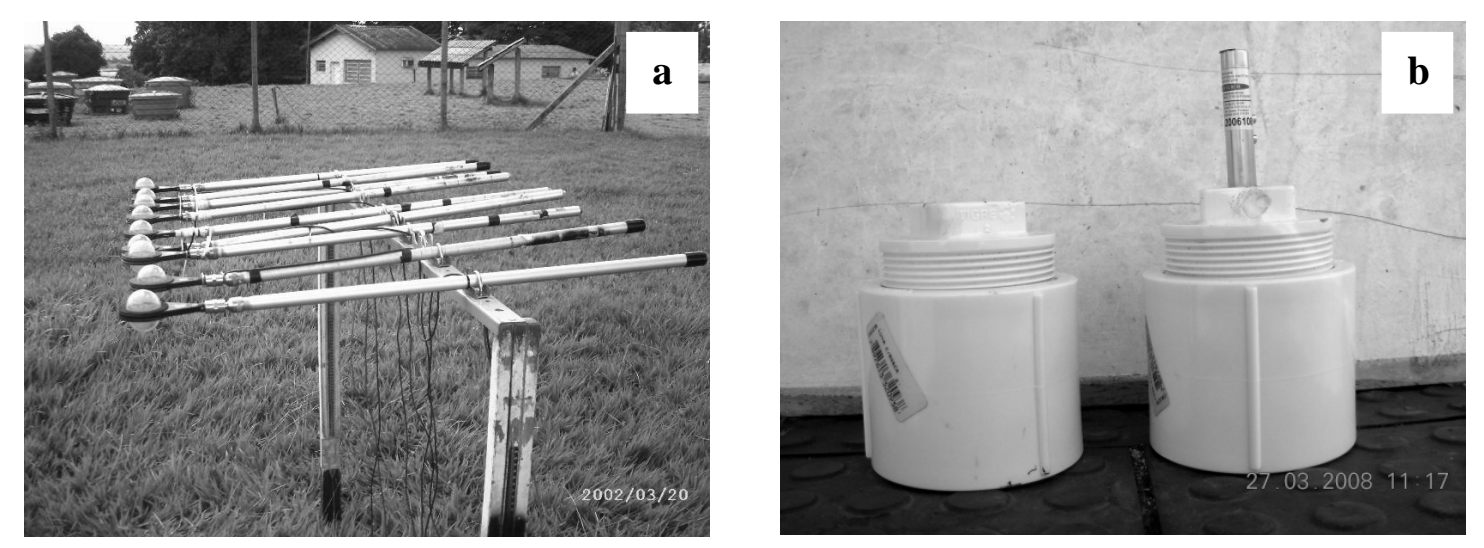

Figura 7 - Calibração dos sensores antes do início do experimento (a); foto ilustrativa do sistema desenvolvido para posicionamento dos saldos-radiômetro (b)

\subsection{Medidas da irradiância solar global e saldo de radiação de gramado}

Os dados de irradiância solar global $(R g)$ e saldo de radiação de gramado $(R n g)$ foram obtidos junto ao posto meteorológico do Departamento de Engenharia de Biossistemas, ESALQ/USP, considerado representativo das condições locais, já que está localizado bem próximo as áreas experimentais usadas neste trabalho. O sensor de irradiância solar global é um piranômetro Kipp \& Zonen (Delft, Holanda), modelo CM3 e o saldo-radiômetro é da mesma marca e modelo daqueles utilizados no sistema integrador.

\subsection{Determinação da radiação solar direta e difusa por modelo proposto}

Nos modelos usados, há necessidade de se conhecer a radiação solar direta e difusa. Por facilidade, normalmente faz-se a medida da irradiância solar global e da difusa, obtendo-se por diferença entre elas o valor da radiação direta, evitando-se o uso de pireliômetros.

Embora a determinação da radiação difusa possa ser realizada pelo uso de instrumental, como um piranômetro sob banda metálica de sombreamento (OLIVEIRA, MACHADO E ESCOBEDO, 2002), a falta do sensor e as dificuldades de precisão no posicionamento da banda mesmo quando existe o instrumental, tem levado ao uso de modelos para estimativa das componentes difusa e direta da radiação solar.

Embora exista um grande número de modelos disponíveis para estimativa de radiação solar direta e difusa sob céu claro, que apresentam considerável acurácia (McCULLOUGH E 
PORTER, 1971), eles requerem dados que geralmente não estão disponíveis e que são difíceis de serem trabalhados. Campbell e Norman (1998) em seus estudos usam um modelo simples baseado em Liu e Jordan (1960), onde $R b$ é função da distância percorrida pelo raio solar através da atmosfera, da transmitância da atmosfera e da densidade de fluxo incidente, expresso pela equação 3:

$$
R b=R_{o} \tau^{m}
$$

onde $R o$ é a densidade de fluxo extraterrestre de radiação solar, $\tau$ é a transmitância da atmosfera e $m$ é o número de massa óptica do ar.

Segundo Campbell e Norman (1998) para ângulos zenitais menores que $80^{\circ}$, os efeitos da refração da atmosfera são negligenciáveis e $m$ é dado pela equação 4:

$$
m=\frac{P a}{101,3 \cos \Psi}
$$

onde $P a / 101,3$ é a razão entre a pressão atmosférica do local e a pressão atmosférica ao nível do mar e $\cos \Psi$ é a correção para efeitos de altitude.

Gates (1980) sugere que valores de $\tau$ entre 0,6 e 0,7 são típicos de dias de céu claro, enquanto valores de $\tau$ de 0,75 indicam dias muito claros, e $\tau$ abaixo de 0,4 indicam dias nublados. Da radiação que chega a atmosfera, parte atinge o solo como radiação direta (equação 3), parte é absorvida pela atmosfera, parte é espalhada para o espaço e parte é espalhada sobre a superfície terrestre. Essa última fração é chamada radiação solar difusa e seu estudo é dificultado porque sua quantidade que atinge o solo depende, em parte, do albedo da superfície.

Negligenciando-se as diferenças entre as superfícies reflectivas, uma aproximação para se obter a radiação solar difusa é o uso de uma equação empírica adaptada de Liu e Jordan (1960), a qual se apresenta abaixo:

$$
R d=0,3\left(1-\tau^{m}\right) R_{o}
$$

onde $R o$ é a densidade de fluxo extraterrestre de radiação solar, $\tau$ é a transmitância da atmosfera e m é o número de massa óptica do ar. 


\subsection{Estimativa do saldo de radiação para limeira ácida 'Tahiti' e renque de cafeeiros utilizando a Lei de Beer modificada (MONSI E SAEKI, 1953).}

Uma das formas de estimativa da energia radiante absorvida pela folhagem de um renque do cafezal e do pomar de limeira ácida, em escala diurna, é a utilização da Lei de Beer modificada. Para esta estimativa necessitou-se dos valores do coeficiente de extinção $(\mathrm{k})$ para o saldo de radiação na copa dos cafeeiros e limeira ácida e o índice de área foliar (IAF). Para a determinação do coeficiente de extinção de luz (k) foram utilizadas as medidas do saldo de radiação no topo e na base do dossel (uso de saldo-radiômetros) e para o índice de área foliar (IAF) as medidas de área foliar e de projeção das copas dos renques de limeira ácida e cafeeiros no solo. O coeficiente de extinção $(\mathrm{k})$ foi determinado pela seguinte equação:

$$
k=\frac{-\operatorname{Ln}\left(\frac{R n i}{R n s}\right)}{I A F}
$$

em que: Rns é o saldo de radiação incidente no topo do renque de cafeeiros ou de limeira ácida; $R n i$ é a medida do saldo de radiação abaixo dos renques; e IAF é o índice de área foliar.

Com a determinação de $\mathrm{k}$ e do IAF, a estimativa do saldo de radiação para os renques estudados pode ser feita por:

$$
R n c, R n l=R g \cdot(1-\alpha) \cdot\left(1-e^{-k \cdot I A F}\right) \cdot A P
$$

em que $R g$ é a irradiância solar global; $\alpha$ o albedo do dossel, determinado conforme descrito no item 3.2; $k$ o coeficiente de extinção; IAF o índice de área foliar; $A P$ a área projetada do renque de cafezal ou limeira ácida sobre o solo.

3.8 Modelo para estimativa de saldo de radiação em renques (RIOU, VALANCOGNE E PIERI, 1989), modificado por Pilau (2005)

Este modelo foi utilizado por Pilau (2005) em seus estudos para estimativa da interceptação da radiação solar, em forma de saldo de radiação, para renques de cafeeiros. O 
modelo foi baseado naquele proposto por Riou, Valancogne e Pieri (1989) para estimativa de interceptação da radiação solar por renques em parreirais.

O modelo envolve o uso de variáveis, tais como geometria do renque, porosidade e albedo do dossel, orientação dos renques e do Sol, e um estudo de interceptação em separado das componentes Rb e Rd da irradiância solar global, como descrito nos itens seguintes.

\subsubsection{Interceptação de radiação solar direta pelo renque}

Assumindo-se que uma linha de plantio isoladamente apresenta geometria simples, na forma de um paralelepípedo, têm-se como áreas de interceptação de radiação solar direta as componentes verticais (Iv) (Equação 8) e a componente horizontal (Ih) (Equação 9) do paralelepípedo. Essas componentes são facilmente entendidas quando são trabalhadas como superfícies planas, em forma de "paredes" interceptando a radiação, uma superior e duas laterais ao renque.

A radiação solar direta $\left(R g_{o}\right)$ interceptada pela superfície horizontal do paralelepípedo $(I h)$ sofre influência direta do ângulo de elevação do sol $(h)$, pois à medida que este ângulo aumenta, a radiação aprofunda-se no interior do dossel. Este mesmo ângulo $(h)$ influencia a interceptação de radiação pelas "paredes" verticais (IV), as quais, também sofrem a influência dos valores de azimute do Sol $a$ e do renque $a^{\prime}$ (Figura 8a e 8b).

$$
\begin{gathered}
I v=A l \cdot \cos h \cdot \operatorname{sen}\left(a-a^{\prime}\right) \cdot R g_{o} \\
I h=A \text { s. sen h. Rgo }
\end{gathered}
$$

em que: $A l$ é a área das paredes laterais do renque e $A s$ é a área da parede horizontal ou superior, $a$ ' é o azimute do renque; $a$ é o azimute do Sol; $h$ é a altura do Sol (90-Z), sendo $Z$ o ângulo zenital e $R g_{o}$ é a radiação solar direta.

Como a superfície horizontal do renque não tem a interceptação de radiação solar influenciada pela orientação de plantio, ou seja, pelo azimute do renque, e também pelos renques adjacentes, a interceptação da radiação solar direta e difusa é tratada conjuntamente, determinando-se a interceptação da irradiância solar global $(R g)$. 
em que: As é a área da parede horizontal ou superior, $h$ é a altura do Sol (90-Z), sendo $Z$ o ângulo zenital e $R g$ é a irradiância solar global.

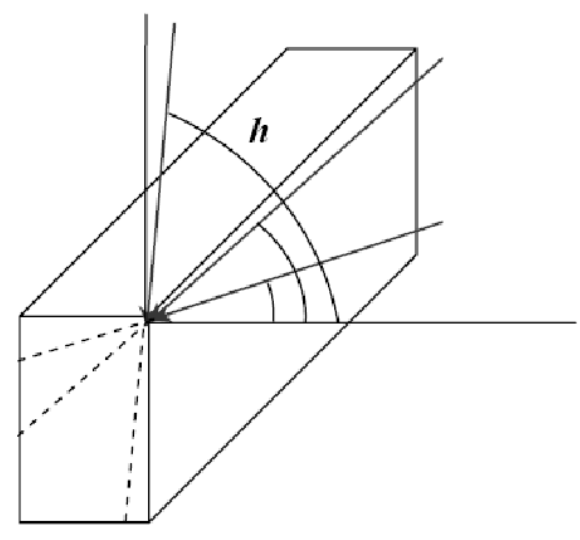

(a)

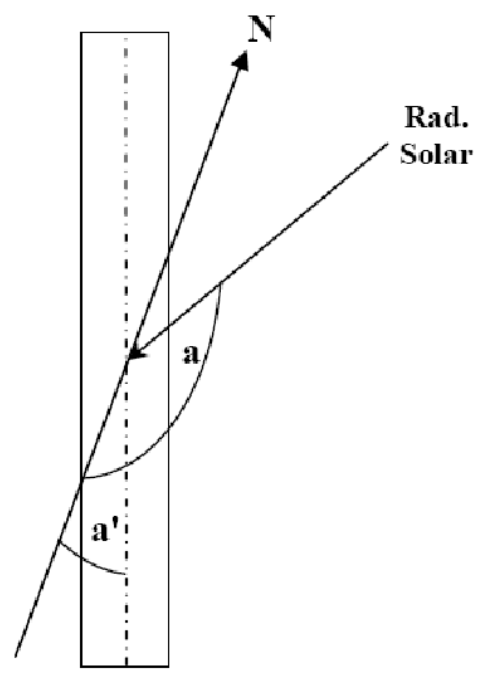

(b)

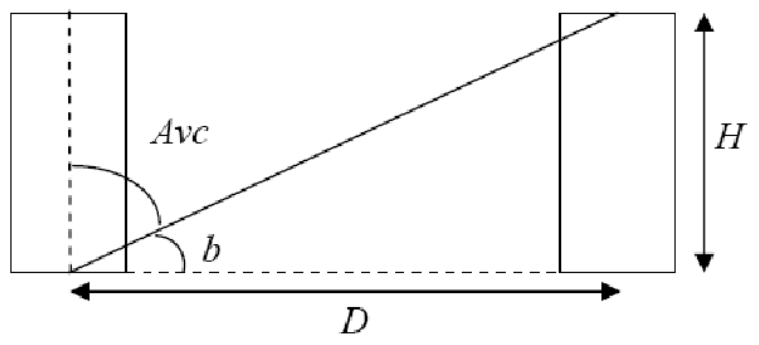

(c)

Figura 8 - Representação do ângulo de elevação solar (h) (a), do azimute do renque ( $\left.a^{\prime}\right)$ e do sol (a) (b); e da área de visada do céu $(A v c)(\mathrm{c})$ no modelo proposto

No volume do paralelepípedo representando a folhagem e ramos de renque, assume-se que as folhas se distribuem aleatoriamente, freqüentemente não o preenchendo totalmente, formando assim espaços vazios, cujo valor integrado representa a porosidade das copas $(p)$. Através da porosidade do renque, parte da radiação solar direta incidente é perdida. Além desta perda em radiação solar direta incidente, outra porcentagem desta é eliminada pela reflexão da folhagem $(\alpha)$. Portanto, para proceder-se a estimativa do saldo de radiação de ondas curtas, devem-se considerar estas reduções, tanto para as componentes verticais (Equação 11) como para a horizontal (Equação 12), ou seja: 


$$
\begin{gathered}
I v=A l \cdot \cos h . \operatorname{sen}\left(a-a^{\prime}\right) \cdot\left[R g_{o} \cdot(1-p) \cdot(1-\alpha)\right] \\
I h=A \operatorname{sen} h \cdot[R g \cdot(1-p) \cdot(1-\alpha)]
\end{gathered}
$$

Através das equações 11 e 12 é possível determinar-se a interceptação de radiação pelas paredes do renque. Para estimar a energia absorvida pelo renque procedeu-se a inclusão de um coeficiente de extinção da irradiância solar global (k'), equação 13:

$$
\begin{gathered}
k^{\prime}=\frac{(R g-I)}{R g} \\
I v=A l \cdot \cos h \cdot \operatorname{sen}\left(a-a^{\prime}\right) \cdot\left[R g_{o} \cdot(1-p) \cdot(1-\alpha)\right] \cdot k^{\prime} \\
I h=A s \cdot \operatorname{sen} h \cdot[R g \cdot(1-p) \cdot(1-\alpha)] \cdot k^{\prime}
\end{gathered}
$$

em que: $I$ é a radiação solar medida sob o dossel e $R g$ é a irradiância solar global.

Foram realizadas modificações na equação 13, substituindo, as medidas de irradiância solar global e radiação sob o dossel, pelo fator porosidade do dossel. Desta maneira o k' foi obtido ajustando-se a equação inicial por regressão contra os valores de porosidade, gerando a seguinte equação:

$$
k^{\prime}=-0,0094 p+0,9461
$$

em que $p$ é a porosidade do dossel.

\subsubsection{Interceptação de radiação solar difusa pelo renque}

\section{A) Caso das "paredes" horizontais}

A interceptação da radiação difusa pela "parede" horizontal superior já está inclusa na equação 10. A interceptação da mesma pela "parede" horizontal inferior do paralelepípedo não foi considerada na interceptação total, pois é dependente de uma fração de radiação difusa que é 
limitada pelos renques vizinhos e pelo próprio renque estudado, do albedo do solo e do albedo de sua folhagem, tornando-se desprezível.

\section{B) Caso das “paredes" verticais}

A interceptação da radiação difusa pelas componentes verticais do renque é dependente da porcentagem de área de visada do céu $(A v c)$, que por sua vez é dependente do espaçamento entre renques $(D)$ e da altura do renque ou de sua folhagem $(H)$ (Figura $8 \mathrm{c}$ ):

$$
A v c=\frac{180-\left(2 \cdot \operatorname{arctg} \frac{H}{D}\right)}{180}
$$

Independentemente do azimute do renque $\left(a^{\prime}\right)$ e do sol $(a)$, as componentes verticais estarão interceptando radiação solar difusa $\left(R g_{d}\right)$. A totalidade da radiação solar difusa absorvida por essas duas componentes é dependente, então, da porosidade e do albedo do renque, da porcentagem de área visada do céu e do coeficiente de extinção de radiação $\left(k^{\prime}\right)$.

$$
I v_{R g_{d}}=2 \cdot A l \cdot R g_{d} \cdot(1-p) \cdot(1-\alpha) \cdot A v c \cdot k^{\prime}
$$

em que: $A l$ é a área das paredes laterais do renque, $R g_{d}$ é a radiação solar difusa, $p$ é a porosidade do dossel, $\alpha$ é o albedo do dossel, $A v c$ é a área de visada do céu e $k$ 'é o coeficiente de extinção de radiação.

Desta forma, pode-se estimar o saldo de radiação para renques de cafezal, computando-se apenas o balanço de energia radiante de ondas curtas da componente horizontal superior e das componentes verticais do renque, conforme equações 14,15 e 18 .

No modelo, o balanço de ondas longas foi desprezado por se considerar que as temperaturas das plantas em estudo, das plantas vizinhas e da superfície vegetada circundante próxima ao renque são semelhantes e apresentam, também, poder emissivo muito similar. Além disso, a temperatura do ar na camada próxima a superfície é similar às anteriores. 


\subsection{Modelo de interceptação da radiação em pomares (OYARZUN , 2005)}

O modelo considera a planta como um corpo poroso de forma prismática. A radiação interceptada pelo pomar é obtida pela relação geométrica entre a estrutura do renque, a posição do Sol e o comprimento da sombra formada pelas árvores.

As informações requeridas para que o modelo proposto possa ser aplicado incluem: altura de árvores $(H)$, altura de inserção dos galhos basais $(B)$ e a largura da cobertura perpendicular a direção da linha $\left(W_{x}\right)$ e ao longo da linha $\left(W_{y}\right)$. Adicionalmente, o modelo requer o espaçamento entre linhas $\left(E_{x}\right)$, a distância entre plantas na linha $\left(E_{y}\right)$ e o azimute da linha $\left(\phi_{r}\right)$, considerado a partir do Sul e aumentando no sentido anti-horário. Também, requer a porosidade da cobertura $\left(C_{p}\right)$, que pode ser estimada pela fração de "olhos de sol” dentro da área sombreada pelas árvores do renque sobre o solo.

Os dados locais requeridos são altitude $(A, m)$, latitude $(\lambda)$, longitude $(\chi)$ e o meridiano padrão do local ( $\chi_{\text {std, }}$, todos em graus) e ainda, se significativos, o grau de inclinação do terreno $(\rho)$ e o azimute da rampa $\left(\phi_{\rho}\right)$. O único dado meteorológico necessário é a irradiância solar global $\left(S_{g, D}\right)$.

\subsubsection{Desenvolvimento do modelo}

\section{A) Relações geométricas Terra-Sol}

As relações aqui apresentadas estão amplamente discutidas e detalhadas nos trabalhos de Campbell e Norman (1998) e Bonan (2002).

Primeiramente, a localização do Sol para um dado momento e local sobre a Terra é determinado. Para isso, o cosseno do ângulo zenital ( $\theta$, em radianos) é obtido para cada hora $(h r)$, através da equação 19.

$$
\cos \theta=\sin \lambda \cdot \sin \delta+\cos \lambda \cdot \cos \delta \cdot \cos \left(0 \cdot 2618\left(h r-t_{o}\right)\right)
$$

onde: $\lambda$ é a latitude do local, $\delta$ é a declinação solar e to é a hora do meio-dia solar.

Obtido o cosseno do ângulo zenital, então o cosseno do azimute solar $\left(\phi_{S}\right)$ pode ser calculado, usando-se (-) para o período da manhã e (+) para o período da tarde, como: 


$$
\cos \phi_{S}= \pm \frac{[\sin \delta-\cos \theta \cdot \sin \lambda]}{\cos \lambda \sin \theta}
$$

Sobre uma superfície inclinada, o desvio angular da perpendicular ao plano horizontal deve ser ajustado para o declive do terreno. Assim o cosseno do ângulo de incidência $(\psi)$, definido como o ângulo entre os raios solares e uma linha imaginária perpendicular ao declive (BONAN, 2002), deve ser levado em conta, o qual é obtido pela equação 21.

$$
\cos \psi=\cos \rho \cdot \cos \theta+\sin \rho \cdot \sin \theta \cdot \cos \left(\phi_{S}-\phi_{\rho}\right)
$$

\section{B) Determinação da radiação horária e sua partição em radiação direta e difusa.}

$\mathrm{O}$ primeiro passo é determinar a irradiância solar extraterrestre diária, $\mathrm{S}_{\mathrm{o}}, \mathrm{D}\left(\mathrm{MJ} \cdot \mathrm{m}^{-2} \cdot \mathrm{d}^{-1}\right)$, obtida pela equação 22 :

$$
S_{o, D}=117 \cdot 5\left(\frac{d}{D}\right)^{2} \cdot \frac{h_{d} \cdot \sin \lambda \cdot \sin \delta+\cos \lambda \cdot \cos \delta \cdot \sin \left(h_{d}\right)}{\pi}
$$

em que: $(d / D)^{2}$ é a variação da distância Terra-Sol e depende do dia do ano e $h_{d}$ é o comprimento do semi-arco diurno (em radianos), usado para determinar a hora do nascer (tss) e do pôr-do-sol (tsr).

A irradiância solar extraterrestre horária $\left(\mathrm{S}_{\mathrm{o}, \mathrm{h}}, \mathrm{em} \mathrm{W} \cdot \mathrm{m}^{-2}\right)$ é obtida pela equação 23 , e a radiação solar global incidente horária $\left(\mathrm{S}_{\mathrm{g}, \mathrm{h}}, \mathrm{em} \mathrm{W} \cdot \mathrm{m}^{-2}\right)$ é obtida segundo Spitters et al. (1986), pela equação 24 :

$$
\begin{gathered}
S_{o, h}=1360 \cdot \cos \theta \\
S_{g, h}=\frac{\left(S_{o, h} \cdot S_{g, D}\right)}{S_{O, D}}
\end{gathered}
$$

em que $S_{\mathrm{g}, \mathrm{D}}$ é a irradiância solar global e $\mathrm{S}_{\mathrm{O}, \mathrm{D}}$ é a irradiância solar extraterrestre diária. 
De acordo com Campbell e Norman (1998), a radiação solar difusa horária $\left(\mathrm{S}_{\mathrm{d}, \mathrm{h}}\right.$, em $\mathrm{W} . \mathrm{m}^{-2}$ ), pode ser determinada pela equação 25 :

$$
S_{d, h}=0.3\left(1-\tau^{m}\right) \cdot S_{o, h}
$$

em que $m$ é a massa óptica do ar, o qual depende da pressão atmosférica ( $P a)$ e do $\cos \theta$ (eq. 4), e $\tau$ é a transmitância diária da atmosfera, obtida pela equação 26 :

$$
\tau=\frac{S_{g, D}}{S_{o, D}}
$$

A irradiância solar direta horária $\left(\mathrm{S}_{\mathrm{b}, \mathrm{h}}, \mathrm{em} \mathrm{W} \cdot \mathrm{m}^{-2}\right)$ é obtida pela equação 27 . E, então, as frações horárias de radiação solar direta $\left(\mathrm{F}_{\mathrm{Sb}, \mathrm{h}}\right)$ e radiação solar difusa $\left(\mathrm{F}_{\mathrm{Sd}, \mathrm{h}}\right)$, podem ser calculadas pelo uso das equações 28 e 29 , respectivamente.

$$
\begin{gathered}
S_{b, h}=S_{g, h}-S_{d, h} \\
F_{S b, h}=\frac{S_{b, h}}{S_{g, h}} \\
F_{S d, h}=\frac{S_{d, h}}{S_{g, h}}
\end{gathered}
$$

Entretanto, sendo $S_{b, h}$ e $S_{d, h}$ calculados para uma superfície horizontal, deve-se levar em conta as seguintes correções, para se obter a irradiância absorvida por uma superfície em declive:

$$
\begin{aligned}
& S *_{d, h}=S_{d, h} \omega \\
& S *_{b, h}=S_{b, h} \beta
\end{aligned}
$$

em que: $\omega$ é um fator que corrige a diminuição da área de visada de céu, visto pela área em declive, à medida que o ângulo de declive aumenta (BONAN, 2002), e $\beta$ é um fator que corrige os efeitos topográficos sobre a incidência de radiação direta (WANG, CHEN E CIHLAR, 2002), 
sendo determinados pelas equações 32 e 33, respectivamente:

$$
\begin{gathered}
\omega=\frac{(1+\cos \rho)}{2} \\
\beta=\frac{\cos \psi}{\cos \theta}
\end{gathered}
$$

(note que se $\rho=0$, isto é, para terrenos planos, ambos $\omega$ e $\beta$ são iguais a 1 , pois $\cos \psi=\cos \theta$ )

Então, a irradiância solar na superfície plana ou com declive, é obtida pela equação 34, utilizando-se os valores corrigidos para condições em que há declive de terreno.

$$
S_{g, h}=S_{b, h}+S_{d, h}
$$

\section{C) Interceptação da radiação direta e difusa.}

O cálculo da fração de radiação que é interceptada pelo renque é baseado na proporção de solo que é sombreado pelas árvores em dado período do dia (Figura 9). Os máximos comprimentos de sombra alcançados pela projeção do renque na perpendicular à linha $\left(\mathrm{L}_{\mathrm{x}}, \mathrm{m}\right) \mathrm{e}$ no sentido da linha de plantio $\left(\mathrm{L}_{\mathrm{y}}, \mathrm{m}\right)$, segundo Cohen, Rao e Cohen (1997), são obtidos pelas seguintes equações:

$$
\begin{aligned}
& L_{x}=H\left[\tan \theta \cdot \sin \left(\phi_{S}-\phi_{R}\right)\right] \\
& L_{y}=H\left[\tan \theta \cdot \cos \left(\phi_{S}-\phi_{R}\right)\right]
\end{aligned}
$$

em que: $H$ é a altura do renque, $\phi_{S}$ e $\phi_{R}$ são o azimute do sol e do renque, respectivamente.

Entretanto, duas correções adicionais devem ser consideradas. Primeiro, leva-se em conta que a cobertura do terreno pelas árvores não se estende sobre a totalidade do chão do pomar. Ao invés disso, há usualmente uma porção do tronco (até a altura de inserção de galhos) que não causa uma sombra significativa, permitindo a passagem de radiação direta que alcança o solo sem obstrução (Figura 9). Desta forma estipula-se um valor de $L_{x, B}$ e um de $L_{y, B}$ para descobrir a 
altura da sombra, empregando-se as mesmas equações acima citadas, substituindo o valor de $\mathrm{H}$ pelo valor de B. Segundo, emprega-se um fator de correção $(\sigma)$ que leva em conta o efeito combinado da posição do Sol, o declive do terreno e o azimute da rampa de declive sobre o comprimento da sombra. Esse fator não foi considerado aqui, pois o trabalho foi realizado em superfície plana. Caso contrário, o fator de correção seria determinado como:

$$
\text { Sendo } \sigma=\left\{\begin{array}{l}
\operatorname{Cos}(\rho), 45^{\circ}<\left(\phi_{S}-\phi_{\rho}\right)<135^{\circ} \\
\frac{1}{\cos (\rho)}, 225^{\circ}<\left(\phi_{S}-\phi_{\rho}\right)<315^{\circ} \\
1, \text { em outros casos. }
\end{array}\right.
$$

O comprimento efetivo de sombra projetado pelas árvores num terreno com ou sem declive, no sentido perpendicular a linha $\left(\mathrm{L}_{\mathrm{x}}^{*}\right)$ ou ao longo da linha de plantio $\left(\mathrm{L}_{\mathrm{y}}^{*}\right)$, é dado por:

$$
\begin{aligned}
& L_{x}^{*}=\left(L_{x}-L_{x, B}\right) \sigma \\
& L_{y}^{*}=\left(L_{y}-L_{y, B}\right) \sigma
\end{aligned}
$$

Desta forma, a fração de solo do pomar que é sombreada em um dado momento $\left(f_{l, h}\right)$, é obtida pela seguinte equação:

$$
f_{l, h}=\frac{\left(\left(L_{x}^{*}+W_{x}\right) W_{y}+\left(L_{y}^{*}+W_{y}\right) W_{x}\right)-\left(W_{x} W_{y}\right)}{E_{x} E_{y}}
$$

a qual é fixada no valor 1,0 , se $f_{l, h}$ tiver valor superior a um (para maiores detalhes consultar o apêndice C (OYARZUN, 2005)).

Desta forma, a fração de radiação direta $\left(f_{b, h}\right)$ que é interceptada pela base do pomar é calculada para cada hora, como:

$$
f_{b, h}=f_{l, h} \cdot\left(1-C_{p}^{*}\right)
$$


O termo $\mathrm{C}_{\mathrm{p}}^{*}$ é uma porosidade efetiva da cobertura vegetal, a qual é obtida pela fração de raios que atingem o solo na área sombreada $(\mathrm{Cp})$ e o coeficiente de absortividade das folhas $(\alpha)$, e é obtido pela equação 41 (maiores detalhes, consultar apêndice D (OYARZUN, 2005)):

$$
\mathrm{C}_{\mathrm{p}}^{*}=\exp \left[\ln \left(\mathrm{C}_{\mathrm{p}}\right) \cdot \sqrt{\alpha}\right]
$$

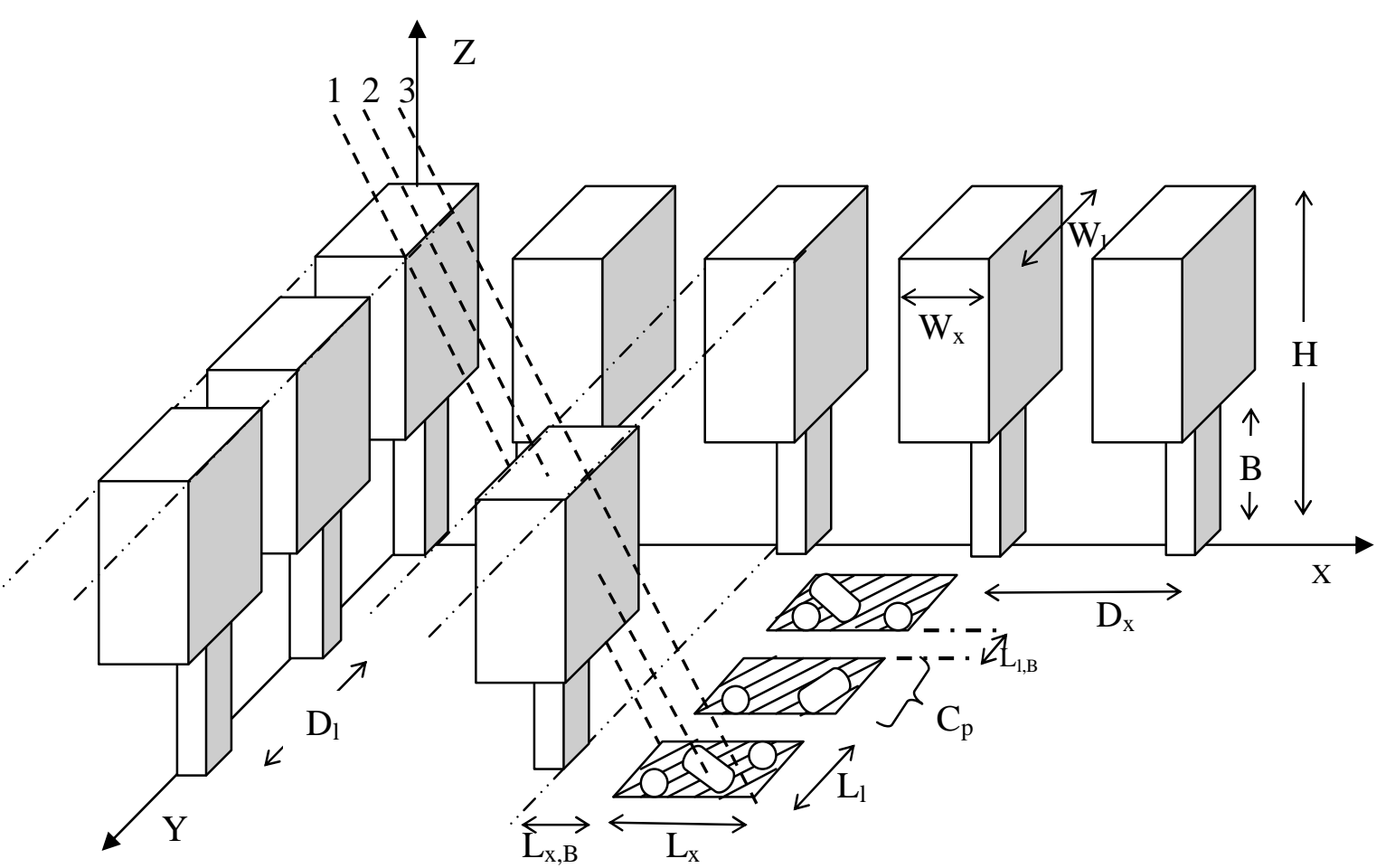

Figura 9 - Representação de um pomar mostrando as variáveis de entrada, configuração do pomar, dimensões da cobertura e porosidade no modelo proposto por Oyarzun (2005). Interação entre os raios solares (---) e as plantas, quando: (1) os raios passam desobstruídos abaixo da cobertura; (2) os raios passam desobstruídos por espaços na folhagem, então se observam "olhos de sol" na área sombreada $\left(\mathrm{C}_{\mathrm{p}}\right)$, e (3) os raios passam pela borda da cobertura, formando uma sombra. Fonte: Oyarzun (2005)

Valores horários de $C_{p}$ são calculados pelo modelo a partir do valor obtido ao meio-dia, o qual é considerado o valor máximo para o dia, iniciando-se e terminando-se com zero, respectivamente ao amanhecer e ao pôr-do-sol, com um incremento/redução linear durante a trajetória do dia. Como brevemente mencionado acima, $C_{p}$ corresponde à radiação que passa desimpedida por aberturas dentro da cobertura e alcança o chão de pomar, e que pode ser observada como manchas iluminadas por raios solares na área sombreada sobre o solo (Figura 9). Deste modo, é conceitualmente equivalente à transmitância da radiação na cobertura para folhas atuando como corpos negros. Considerando que as folhas reais não são corpos negros, um 
coeficiente de absortividade é usado para responder pela radiação que se espalha, resultante da reflexão e transmissão através de folhas (CAMPBELL E NORMAN, 1998). Medidas de campo foram usadas para avaliar o modelo, considerando só a fração PAR da radiação. Entretanto, um valor de $\alpha=0,85$ foi selecionado, baseado em estudos existentes de coeficientes de absortividade de folhas em frutíferas como videira (SCHULTZ, 1996), cerejeira (CITTADINI et al., 2002), e macieira (GREEN et al., 2003). Para Rg considera-se $\alpha=0,5$, levando-se em conta, o maior espalhamento que existe quando o espectro solar total é considerado (CAMPBELL E NORMAN, 1998), embora a mesma série de equações e sucessão de cálculos seja aplicada.

Desta forma, a transmitância da radiação direta $\left(\tau_{\mathrm{b}, \mathrm{h}}\right)$ para a base do pomar é obtida para cada hora pela equação 42 , e a transmitância média efetiva $\left(\tau_{\mathrm{d}, \mathrm{D}}\right)$, numericamente, obtida pela equação 43:

$$
\begin{gathered}
\tau_{b, h}=1-f_{b, h} \\
\tau_{d, D}=2 \sum_{h-t s r+1}^{h-t s s} \tau_{b, h} \cdot \cos \theta_{h} \cdot \sin \theta_{h} \cdot d \theta_{h-(h-1)}
\end{gathered}
$$

A fração de radiação difusa interceptada pelo pomar é obtida como:

$$
f_{d, D}=1-\tau_{d, D}
$$

Deste modo, a fração horária de interceptação de radiação é obtida por:

$$
f_{S g, h}=f_{b, h}+f_{d, D}
$$

A radiação absorvida pelo dossel numa escala horária pode ser obtida pela equação 46, e o valor diário é estimado pela integração de todos os valores obtidos na escala horária.

$$
S g_{i, h}=S_{g, h} \cdot f_{S g, h}
$$

sendo: $S g_{i, h}$ a quantidade de radiação interceptada pelo renque em escala horária; $S_{g, h}$ a irradiância solar global medida acima do topo da cobertura em escala horária; e $f_{S g, h}$ a fração de radiação que é interceptada pela renque. 


\subsection{Teste dos Modelos}

Os valores estimados de saldo de radiação em cafezal e pomar de limeira ácida, pelos modelos propostos, foram comparados com as medidas diretas obtidas a campo pelo sistema de integração nas escalas de 15min, uma hora e um dia, por análise de regressão. Para análise estatística, a fim de se avaliar a desempenho dos modelos contra a medida obtida diretamente a campo, foram utilizados o índice de concordância D de Willmott (WILLMOTT, 1982), o erro médio absoluto MAE, expresso em percentagem da média dos valores observados (ANNANDALE et al., 2004) e o coeficiente residual de massa CRM (LOAGUE e GREEN, 1991). As equações que denotam cada relação são apresentadas abaixo:

$$
\begin{gathered}
D=1-\left[\frac{\sum_{i=1}^{N}\left(E_{i}-O_{i}\right)^{2}}{\sum_{i=1}^{N}\left(\left|E_{i}^{\prime}\right|+\left|O_{i}^{\prime}\right|\right)^{2}}\right], 0 \leq D \leq 1 \\
M A E=\frac{\sum_{i=1}^{N}\left(E_{i}-O_{i}\right)}{N} \times 100 \\
C R M=\frac{\sum_{i=1}^{n} O_{i}-\sum_{i=1}^{n} E_{i}}{\sum_{i=1}^{n} O_{i}}
\end{gathered}
$$

em que: $\mathrm{E}_{\mathrm{i}}$ é o valor estimado, $\mathrm{O}_{\mathrm{i}}$ é o valor observado, $E_{i}^{\prime}=E_{i}-\bar{O}$ e $O_{i}^{\prime}=O_{i}-\bar{O}$ e $\mathrm{N}$ é o número de observações.

Os valores ótimos de MAE e CRM criteriosamente seriam zero. Para D, o valor unitário expressa a concordância perfeita entre os valores observados e estimados, enquanto o valor zero descreve total discordância entre valores. MAE é a percentagem do valor médio radiação interceptada (Rn), seja na escala de $15 \mathrm{~min}$, horária ou diurna. Valores positivos de CRM indicam que o modelo subestima as medidas, enquanto valores negativos indicam superestimativa. Segundo De Jager (1994), como critérios para garantir a confiabilidade do modelo os valores de $\mathrm{R}^{2}$ e D devem ser superiores a 0,8 , enquanto o valor de MAE, expresso em percentagem, deve ser inferior a $20 \%$. 


\section{RESULTADOS E DISCUSSÃO}

\subsection{Teste de balanceamento (desvio do zero) dos sensores no sistema móvel}

A montagem dos saldo-radiômetros no arco de suporte deve permitir um balanceamento em cada par de sensores opostos, permitindo idealmente um valor nulo quando a medida é realizada sem a copa de árvores no interior do sistema.

Na Figura 10 apresentam-se os cursos diários de variação do saldo de radiação para períodos de $15 \mathrm{~min}$ sem a presença de plantas no interior do arco, para quatro dias e em três situações observadas com o objetivo de verificar o "balanceamento". Na Figura 10a são apresentados os valores observados com o equipamento usado no cafezal posicionado no sentido Norte-Sul, ou seja, numa posição em que os braços dos sensores, fixados perpendicularmente ao arco, apresentavam orientação nesse sentido. São observados dois picos para cada dia, um de valores negativos com máximos ao redor de $-160 \mathrm{~W} \cdot \mathrm{m}^{-2}$ em torno das 11 horas e um de valores positivos, atingindo $120 \mathrm{~W} \cdot \mathrm{m}^{-2}$ ao redor de 13 horas para o dia com maior variabilidade. Na Figura 10b são apresentados os valores observados com o equipamento posicionado no sentido Leste-Oeste com dois picos para cada dia, um de valores negativos, com valor máximo de -45 W. $\mathrm{m}^{-2}$ e um de valores positivos atingindo $70 \mathrm{~W} \cdot \mathrm{m}^{-2}$ nas primeiras horas da manhã. O mesmo é observado na Figura 10c, para o teste de equipamento no experimento de limeira ácida, orientado no sentido Leste-Oeste, onde ocorreram dois picos para cada dia, um de valores negativos, alcançando valores ao redor de $-60 \mathrm{~W} \cdot \mathrm{m}^{-2}$ entre 7 e 8 horas da manhã e um de valores positivos de $100 \mathrm{~W} . \mathrm{m}^{-2}$ entre 11 e 12 horas.

Como média diária geral dos três casos mostrados encontrou-se valores de desvios em torno de $13 \mathrm{~W} \cdot \mathrm{m}^{-2} .15 \mathrm{~min}^{-1}$, que integrados resultam numa média de $0,012 \mathrm{MJ} \cdot \mathrm{m}^{-2} \cdot \mathrm{dia}^{-1}$, valor este que equivale a menos de $1 \%$ do valor diário de saldo de radiação, que na época do ano com menores valores de radiação apresenta média de 7,8 MJ.m ${ }^{-2} \cdot$ dia $^{-1}$. O valor encontrado é bem abaixo do valor máximo de 5\% sugerido como aceitável no estudo realizado por McNaughton et al. (1992), em função do desbalanceamento e de erros de calibragem dos sensores. Grande parte do desvio do nulo originado é devido aos desvios observados para cada direção de posicionamento, tendo relação com a própria estrutura do equipamento que, em alguns horários do dia, promove sombreamento de sensores localizados nas posições inferiores do arco de 
amostragem, desbalanceando a leitura do par correspondente de sensores. Além disso, há erros provocados pela fuga da linha imaginária que liga as faces de um par de sensores e deveria passar pelo centro da esfera formada pelos sensores. Testes como estes são de extrema importância nesses estudos, pois se tratando de radiação solar, pequenos desvios do posicionamento correto dos sensores podem provocar uma grande diferenciação nos valores finais observados.
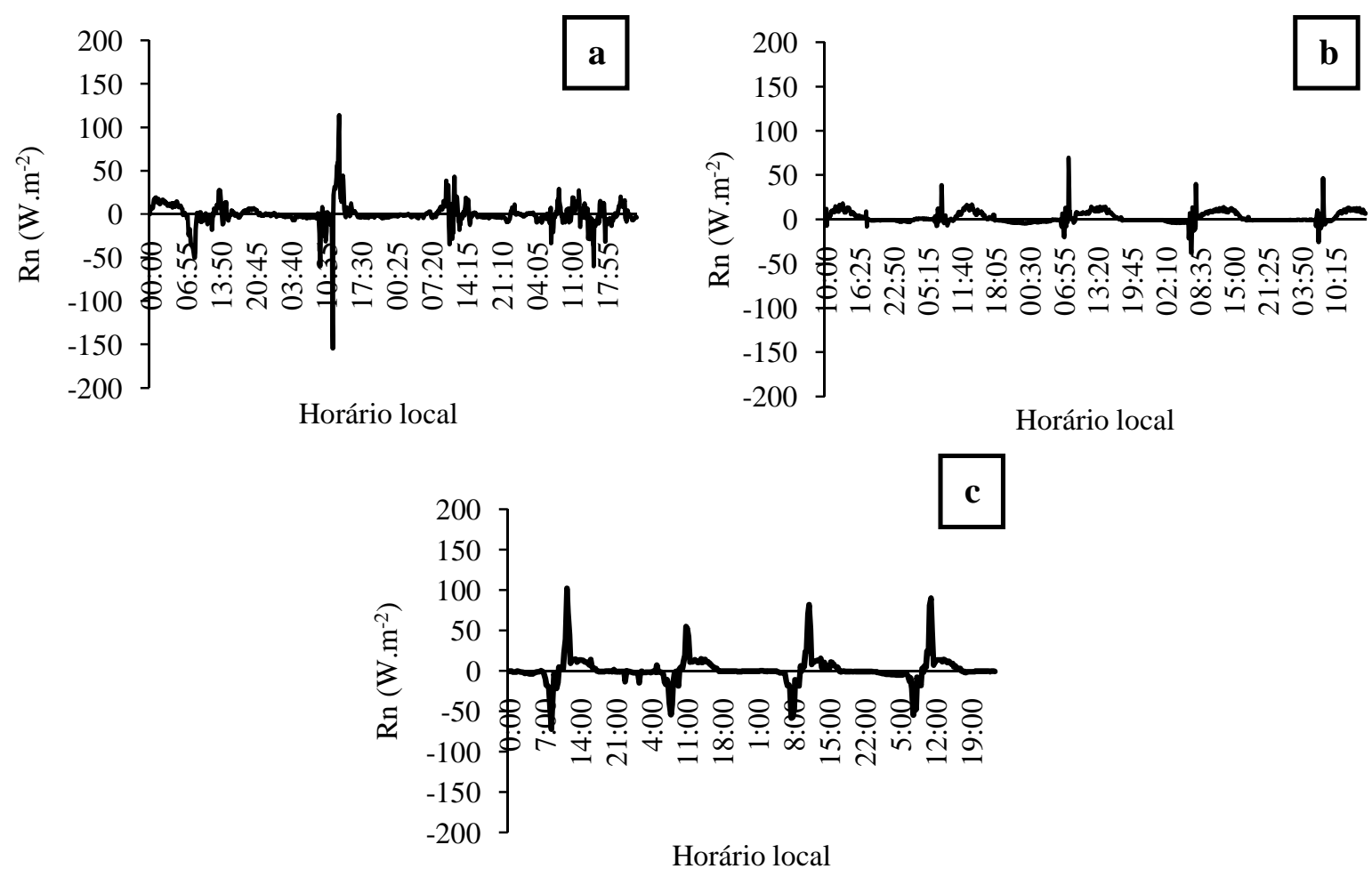

Figura 10 - Variação dos desvios de balanço nulo das medidas de Rn sem a presença de plantas no interior do sistema, para intervalos de 10min durante 4 dias no sentido Norte-Sul(a) e Leste-Oeste (b) no cafezal e no sentido Leste-Oeste(c) para o pomar de limeira ácida, em Piracicaba, SP

\subsection{Desempenho dos sistemas integradores}

Conforme discutido por McNaughton et al. (1992), é muito difícil avaliar a consistência e o grau de erro das medidas obtidas no sistema integrador.

Uma possibilidade é comparar o saldo de radiação da copa com o valor de calor latente de vaporização (transpiração) das árvores, de maneira a se verificar se esse calor latente representa, em boas condições de disponibilidade hídrica, entre 70 a $80 \%$ do saldo de radiação na copa. Para 
o cafezal, procedimentos nesse sentido já demonstraram que as determinações integradas no sistema são consistentes e confiáveis (MARIN, 2003; ANGELOCCI et al., 2008).

No caso do sistema instalado no pomar de limeiras ácidas, tomando por base a transpiração de uma árvore instalada em lisímetro de célula de carga, com área foliar cerca de $15 \%$ superior às árvores utilizadas no sistema integrador (IRIGOYEN ${ }^{1}$, informação verbal), verificou-se que para o período das 9 as 17 horas de três dias do mês de março de 2009, o calor latente de vaporização da árvore do lisímetro correspondeu a 94\% do saldo de radiação médio integrado por árvore. Considerando uma correção para a diferença de área foliar entre as árvores do sistema integrador e a do lisímetro, encontrou-se um valor de calor latente equivalente a $81 \%$ do saldo de radiação médio para cada árvore nos três dias. Uma confirmação adicional da ordem de grandeza da relação calor latente $(\lambda \mathrm{E})$ com o saldo de radiação $(\mathrm{Rnl})$ foi obtida durante o verão, com o lisímetro com solo descoberto, de modo que o calor latente incluía, também, a evaporação do solo. Nesse caso, a relação média para sete dias de dezembro de 2008 entre $\lambda \mathrm{E}$ e Rnl, foi igual a 0,88 (SIMON et al., 2009), o que representa um valor aceitável, considerando-se que ele compõe-se, também, da evaporação do solo.

Para o sistema integrador do pomar de limeiras ácidas, um problema prático foi a verificação contínua das condições das placas sensoras e a manutenção das cúpulas plásticas, devido a dimensão do sistema dificultar a observação dos sensores superiores. Apesar dessas dificuldades, os resultados relatados a seguir permitem concluir sobre o bom desempenho de ambos os sistemas sobre a magnitude dos dados de saldo de radiação das copas na linha de plantio, mas não com relação a sua consistência. Uma discussão adicional sobre este ponto será feita no item 4.8 .

\subsection{Variação temporal do saldo de radiação em renques em função da posição dos saldo- radiômetros em torno das copas}

\subsubsection{Cafezal}

Na Figura 11 observam-se as curvas de medida de cada saldo-radiômetro para os dias julianos 142, 212, 303 no ano de 2008 e 32 no ano de 2009, sendo cada um representativo de quatro estações de medidas, escolhidos por apresentar o maior valor de saldo de radiação 
integrado no dia, considerando-se o período diurno aquele compreendido entre o nascer e o pôrdo-sol.

Devido à orientação noroeste-sudeste dos renques, com azimute de $27^{\circ}$ a partir do sul, a face lateral do renque voltada para leste recebeu maior insolação no período da manhã, verificada pelos altos valores encontrados nos saldo-radiômetros Rn5 e Rn6, e a face voltada para oeste recebeu maiores valores no período da tarde nos saldo-radiômetros Rn3 e Rn4.

Saldo-radiômetros posicionados nas mesmas latitudes de montagem, porém em lados opostos do arco, tendem a apresentar simetria temporal de medidas, tendo as medidas integradas dos saldo-radiômetros Rn3, Rn4, Rn5 e Rn6 no dia valores positivos e os demais saldoradiômetros, na média, valores negativos. Como a orientação dos renques não segue o sentido norte-sul com exatidão, nota-se que os picos de radiação são maiores no período da manhã e menores no período da tarde, exceção feita ao verão onde os valores apresentaram-se equivalentes. Nesta época do ano, o Sol apresenta um ângulo zenital menor, pois a declinação solar é muito próxima do valor de latitude do local, diminuindo o efeito provocado pela orientação do renque.

Curvas similares de variação de Rn foram observadas por Marin (2003) para dias julianos que englobavam as estações de inverno e primavera, e por Pilau (2005) para dias julianos de outono, ambos utilizando-se do mesmo sistema móvel de integração utilizado neste estudo. Gutierrez e Meinzer (1994) trabalhando com um cafezal em orientação leste-oeste, encontraram valores máximos de Rn com magnitude idêntica aos encontrados nas posições dos saldoradiômetros Rn4 e Rn5 (superiores), porém com conformação diferenciada das curvas.

Variações ao longo da noite de Rn foram verificadas para duas estações do ano (inverno e verão). As medidas foram obtidas com o sistema de medidas estacionário, pois segundo Pilau (2005), à noite não há diferenças significativas entre os valores obtidos com o sistema em movimento ou estacionário, não havendo diminuição da precisão das medidas. Durante o período noturno somente ocorre o balanço de ondas longas, que incorpora fluxos de troca radiante com o firmamento e entre a vegetação dos renques. Os valores são mais negativos para os dois saldoradiômetros superiores $(\mathrm{Rn} 4 \mathrm{e} \mathrm{Rn} 5)$ que tem a face das placas sensoras externas às plantas do renque expostas ao firmamento. Os demais sensores, localizados em posições em que as faces externas das placas sensoras têm em parte o campo de visada para o firmamento e parte para o dossel, apresentam balanço menos negativo que os dois saldo-radiômetros superiores. 

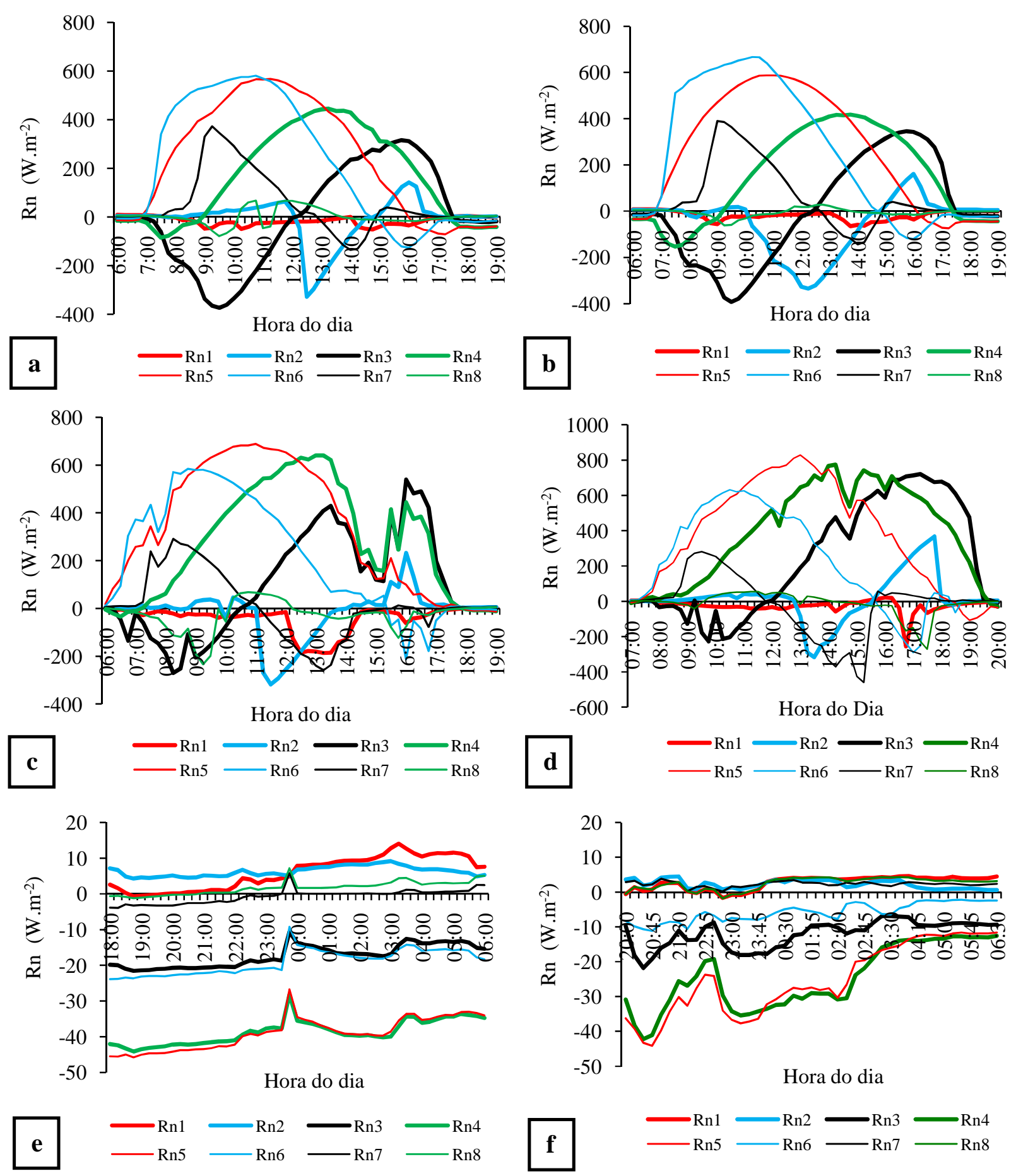

Figura 11 - Evolução temporal dos valores de saldo de radiação em cada posição de medida dos oito saldoradiômetros do sistema móvel integrador, para os dias julianos 142 (a), 212 (b), 303 (c) de 2008 e 32 (d) de 2009 no período diário e para os dias julianos 212 (e) de 2008 e 32(f) de 2009 no período noturno 
Os saldo-radiômetros que tem suas visadas (duas faces) cobrindo praticamente o dossel vegetativo e/ou solo indicam saldos de radiação próximos a zero, predominando valores ligeiramente positivos (até cerca de $10 \mathrm{~W} . \mathrm{m}^{-2}$ ). A variação dos valores negativos nos quatro sensores superiores é muito pequena ao longo da noite no inverno, tendendo a diminuir levemente. Já no verão, a diminuição dos valores negativos foi mais acentuada para os dois sensores localizados no nível superior, variando de $-40 \mathrm{~W} \cdot \mathrm{m}^{-2}$ no início da noite até cerca de -15 W.m $\mathrm{m}^{-2}$ na madrugada.

Quando se leva em consideração a variação sazonal das medidas diurnas de Rn (Figuras 11a, 11b, 11c e 11d), conclui-se que a medida que se aproxima o verão, com maior altura solar média, as curvas tendem a apresentar uma similaridade de comportamento entre os períodos da manhã e da tarde.

\subsubsection{Limeira Ácida}

Na Figura 12 apresentam-se as curvas de medida de cada saldo-radiômetro para os dias julianos 358 (2008) e 99 e 174 (2009), cada um representativo de uma estação do ano, escolhidos por apresentarem valores elevados de saldo de radiação, em dias de baixa nebulosidade. Devido à orientação praticamente leste-oeste dos renques, com azimute de $89^{\circ}$ a partir do sul, o Sol se deslocava na direção do eixo da linha de plantio, o que resulta em um padrão de variação das medidas nas diferentes posições de instalação completamente diferente do observado nos renques de cafeeiros, com outro sentido da linha de plantio. Os sensores posicionados entre o extrato médio e a parte superior das copas indicam saldos de radiação positivos ao longo do período diurno, enquanto os posicionados entre a altura média e o extrato inferior das copas tendem a apresentar valores negativos, parte deles próximos de valores nulos.

Quando se observa a variação sazonal das medidas de Rn diurnas (Figuras 12a, 12c e 12e), nota-se um comportamento distinto para o verão. Para o dia mostrado, muito próximo ao solstício de verão, a declinação solar é superior ao valor de latitude do local, proporcionando uma maior insolação na face sul da linha de renque, sendo observada pelos maiores valores de Rn obtidos nos saldo-radiômetros Rn5 e Rn6. Nas estações seguintes, em que a declinação solar está próxima a zero (equinócio) e a $23,45^{\circ} \mathrm{N}$ (inverno), a face voltada ao norte passa a ser mais 
insolada, determinando que os valores de $\mathrm{Rn}$ sejam mais elevados nos radiômetros $\mathrm{Rn} 7$, $\mathrm{Rn} 8$, Rn9 e até mesmo no Rn10 no inverno.
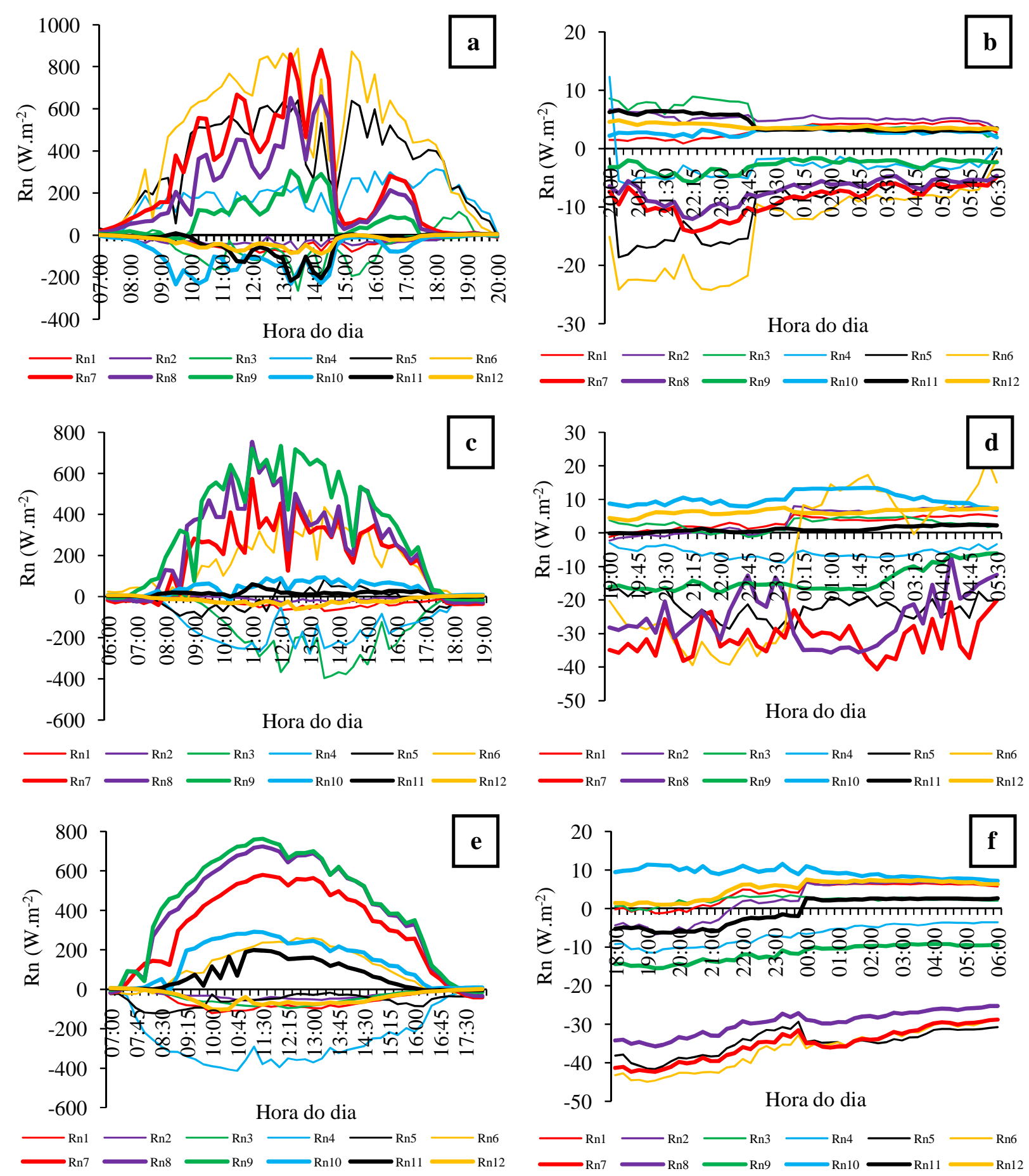

Figura 12 - Evolução temporal dos valores de saldo de radiação em cada posição de medida dos doze saldoradiômetros do sistema móvel integrador instalado no pomar de limeiras ácidas, para os dias julianos 358 (a,b) de 2008, 99 (c,d) e 174 (e,f) de 2009, nos períodos diurno e noturno 
A variação noturna do saldo de radiação (Figuras $12 \mathrm{~b}, 12 \mathrm{~d}$ e $12 \mathrm{f}$ ) exibe um padrão não muito diferente do encontrado no cafezal, sendo a explicação dada quando da discussão nessa cultura, válida, também, para o presente caso. Os saldo-radiômetros instalados na parte superior das copas apresentam valores negativos durante todo o período, tendendo a tornarem-se menos negativos com o avanço na madrugada. Valores nulos ou positivos são observados para os sensores posicionados na parte inferior do arco.

\subsection{Relações do saldo de radiação dos renques com a irradiância solar global e o saldo de radiação de gramado}

\subsubsection{Cafezal}

Os valores de saldo de radiação do renque (Rnc), expressos por unidade de área projetada no solo, obtidos no outono (abril-maio) mostraram-se linearmente correlacionados com a irradiância solar global (Rg) e o saldo de radiação de gramado (Rng), sendo os melhores ajustes obtidos com valores de Rnc integrados na escala diurna e com a variável irradiância solar global (Figura 13f). Dados obtidos a cada 15min apresentaram um baixo grau de dispersão e boa linearidade entre as medidas para esta época do ano (Figura 13a, 13b), diferentemente de Marin (2003) e Pilau (2005) que verificaram uma relação não-linear melhor caracterizada por meio de equações polinomiais de $2^{\circ}$ grau, para esta escala de tempo. Foram usadas regressões forçadas ou não a passar pelo zero, sendo escolhidas em função do maior valor de $\mathrm{R}^{2}$. Toda vez em que não ocorria diferença significativa entre os valores de $\mathrm{R}^{2}$ nos dois tipos de ajuste, escolheu-se apresentar a regressão com passagem pelo ponto de origem dos eixos. Os valores máximos de Rnc para este período alcançaram $0,59 \mathrm{MJ} \cdot \mathrm{m}^{-2} \cdot 15 \mathrm{~min}^{-1}$, inferiores aos encontrados por Pilau (2005) em um cafezal adulto. Esses valores inferiores foram devidos à menor altura e área foliar, bem como maior espaçamento entre linhas no presente estudo, provocando menor absorção de energia radiante e menor interação radiativa entre renques, além da defasagem temporal em torno de 30 dias entre os períodos do ano em que os dois estudos foram realizados.

Ao se trabalhar na escala horária, o ajuste melhora tanto para Rng quanto Rg, embora as relações lineares se mantenham (Figura 13c, 13d). Mesmo na escala horária, observam-se valores negativos de Rnc, em condições de baixa Rg, situação que ocorre próxima ao nascer e ao pôr-do- 
sol. Nesse momento o balanço de ondas longas se torna predominante, e as perdas de energia do dossel são maiores que a energia fornecida de forma direta (Figura 13d).
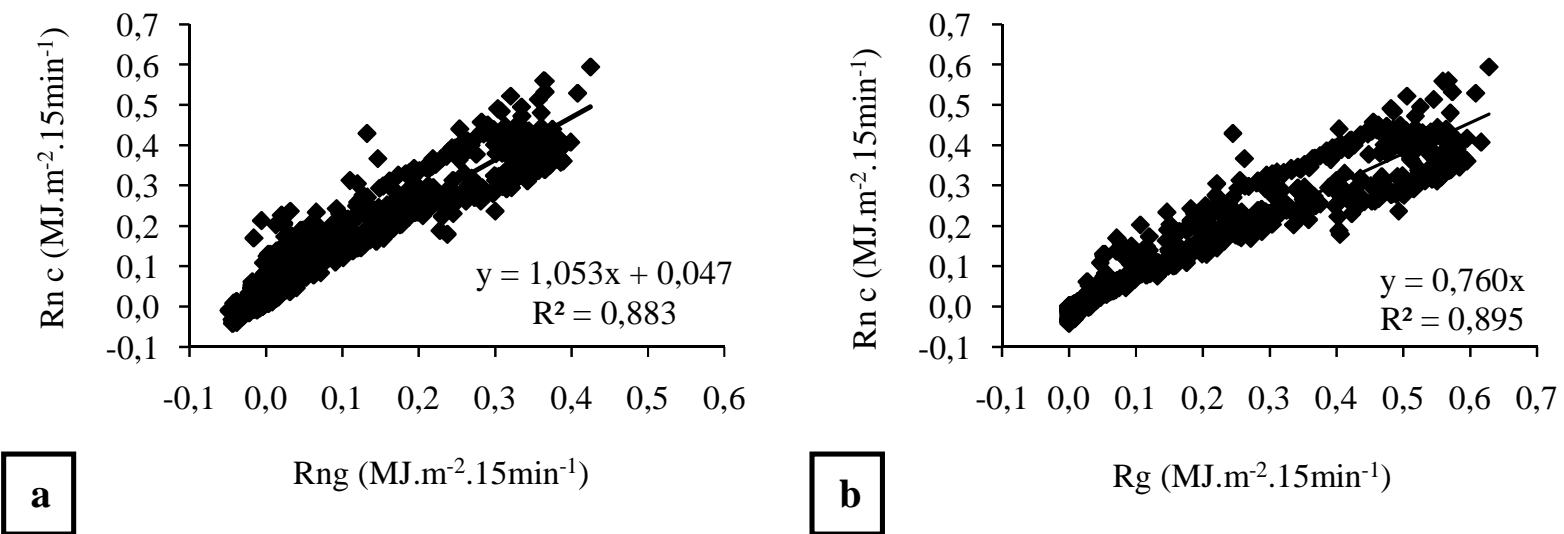

Rng $\left(\mathrm{MJ} \cdot \mathrm{m}^{-2} .15 \mathrm{~min}^{-1}\right)$

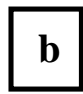

$\operatorname{Rg}\left(\mathrm{MJ} . \mathrm{m}^{-2} .15 \mathrm{~min}^{-1}\right)$
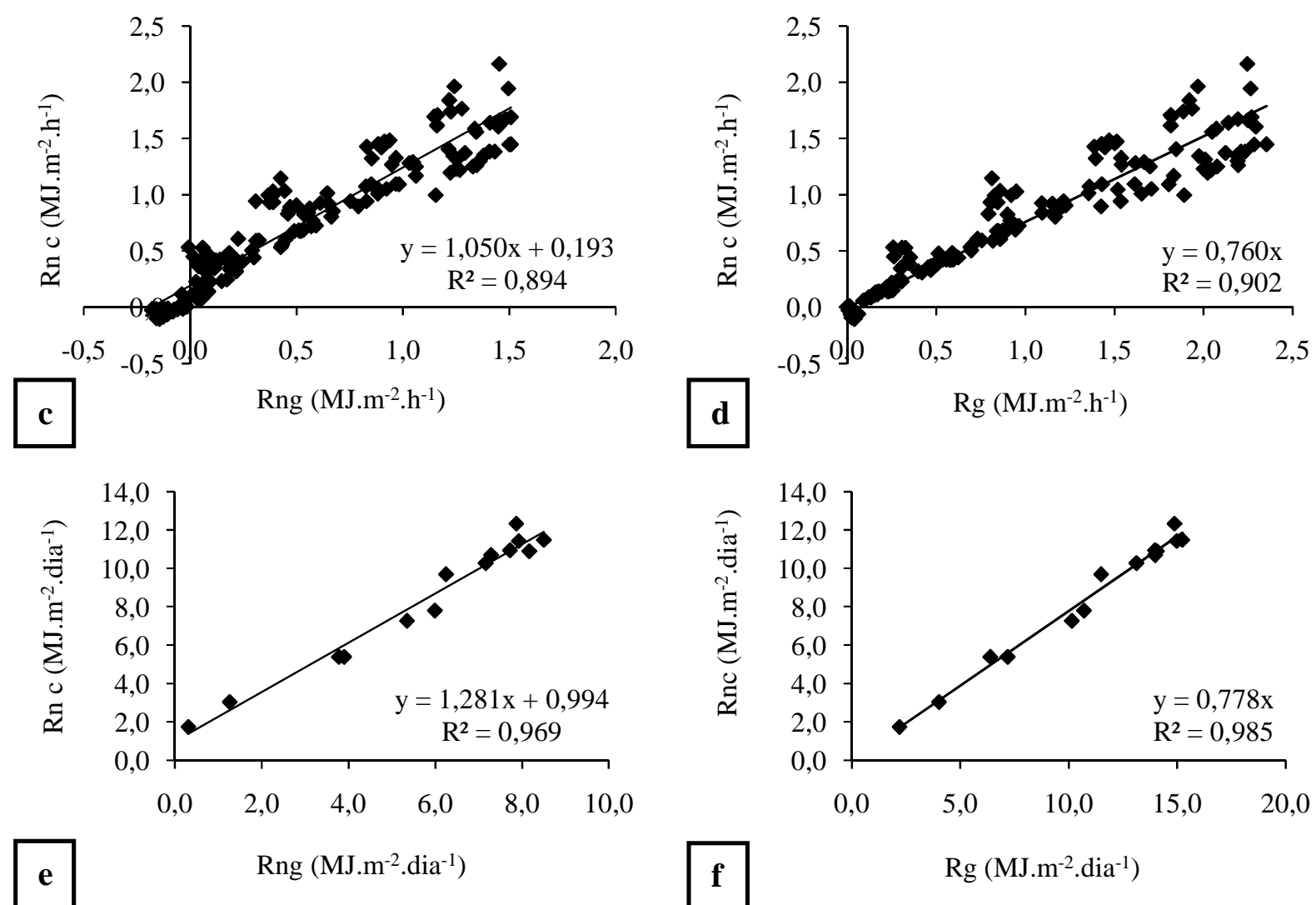

Rng $\left(\mathrm{MJ} \cdot \mathrm{m}^{-2} \cdot \mathrm{dia}^{-1}\right)$

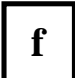

$\operatorname{Rg}\left(\mathrm{MJ} \cdot \mathrm{m}^{-2} \cdot \mathrm{dia}^{-1}\right)$

Figura 13 - Relações do saldo de radiação de renque de cafeeiros (Rnc) com o saldo de radiação de gramado (Rng) e a irradiância solar global ( $\mathrm{Rg}$ ) nas escalas de $15 \mathrm{~min}(\mathrm{a}, \mathrm{b})$, horária (c,d) e diurna (e,f) para outono (DJ $133,134,138$ a 142 e 147 a 153), Piracicaba, 2008

Contrariamente, quando se compara o Rnc ao Rng, verificam-se valores de Rnc positivos em momentos onde Rng ainda está negativo (Figura 13c). Essa interação que ocorre entre as 
plantas de um renque e o meio circundante, com ganhos de energia radiante advinda das adjacências, promove um balanço positivo para o dossel, principalmente no final do dia, enquanto que no gramado, caracterizado por uma superfície plana, com horizonte aberto, ocorrem perdas de ondas longas mais significativas, a partir do momento que $\mathrm{Rg}$ se torna nula. Na escala diurna, os ajustes tornam-se mais significativos com $\mathrm{R}^{2}$ muito próximo ao valor máximo. Para esta escala, o Rnc foi 22,2\% inferior aos valores de $\mathrm{Rg}$, o que corresponde um aproveitamento de aproximadamente $78 \%$ da radiação incidente na horizontal (Figura 13f).

Para o outono, Pilau (2005) encontrou uma relação linear de Rnc com Rg, com Rnc correspondendo a $42 \%$ de Rg, mas com um intercepto de 8,5 MJ.m $\mathrm{m}^{-2} \cdot \mathrm{dia}^{-1}$, que nas condições de seu estudo, correspondiam na média a $50 \%$ da irradiância solar global na superfície.

O valor diário de Rnc foi entre 30 a 40\% maior que Rng (Figura 13e). Pilau (2005) encontrou Rnc em torno de 50\% inferior ao Rng, mostrando uma relação bem inferior a encontrada neste trabalho. Provavelmente o maior espaçamento e a menor área foliar por metro linear de renque (20\% inferior) foram os responsáveis pela menor interceptação de energia radiante, e menor interação com renques adjacentes.

No inverno (julho) uma relação quadrática entre os dados de saldo de radiação de renque (Rnc) com os dados de saldo de radiação de gramado (Rng) e irradiância solar global (Rg) para a escala de $15 \mathrm{~min}$ e a escala horária (Figuras $14 \mathrm{a}$ a $14 \mathrm{~d}$ ) mostrou-se mais adequada, também verificada por Marin (2003) e Pilau (2005). A concordância manteve-se alta, tanto na escala de 15 min, quanto na escala horária, com valores de $\mathrm{R}^{2}$ alcançando 0,93 e 0,92 para Rng (Figuras 14a e 14c) e Rg (Figuras 14b e 14d), respectivamente. Quando os dados são integrados na escala diurna, transforma-se a relação quadrática para linear, que embora sofra diminuição nos valores de $\mathrm{R}^{2}$, mantêm-se boa para a irradiância solar global, com valor de 0,86 . Na relação de Rnc com o Rng, em escala diurna, encontraram-se valores de $\mathrm{R}^{2}$ abaixo de 0,7 , mostrando uma maior dispersão nos dados. O Rnc correspondeu a aproximadamente $76 \%$ da irradiância solar global para esta estação do ano. Esse valor foi muito próximo ao valor encontrado para a condição de outono, onde o Rnc correspondeu a 78\% de Rg. Comparando-se ao Rng, o Rnc foi entre 30 e $40 \%$ maior, ou seja, uma relação praticamente igual à encontrada para o período de outono. 

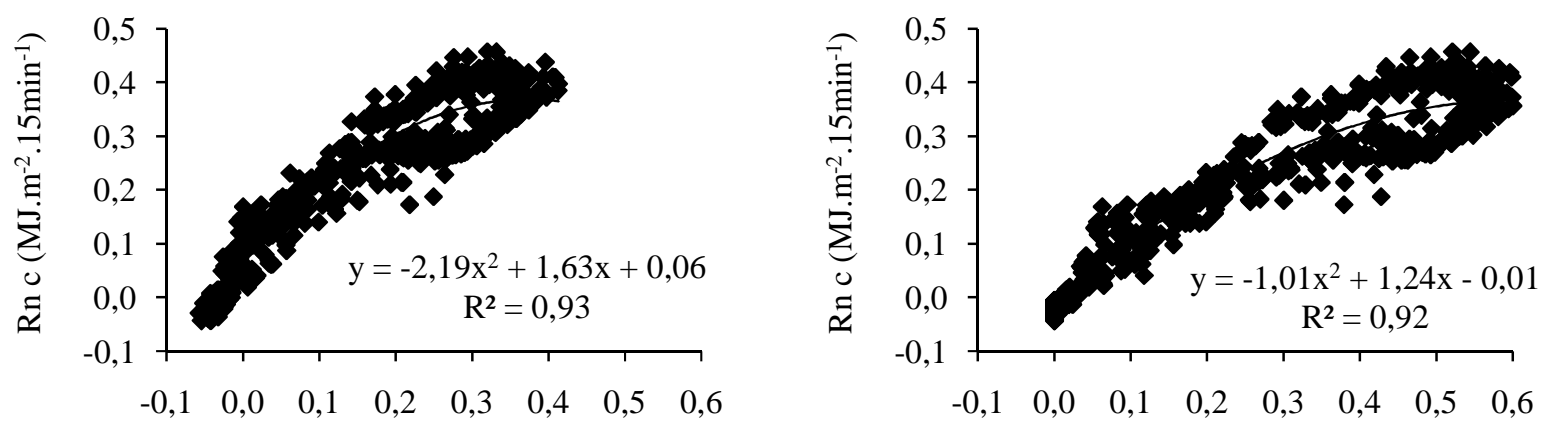

$\mathbf{a}$

Rng (MJ.m-2 $\left..15 \mathrm{~min}^{-1}\right)$

b

$\operatorname{Rg}\left(\mathrm{MJ} \cdot \mathrm{m}^{-2} \cdot 15 \mathrm{~min}^{-1}\right)$
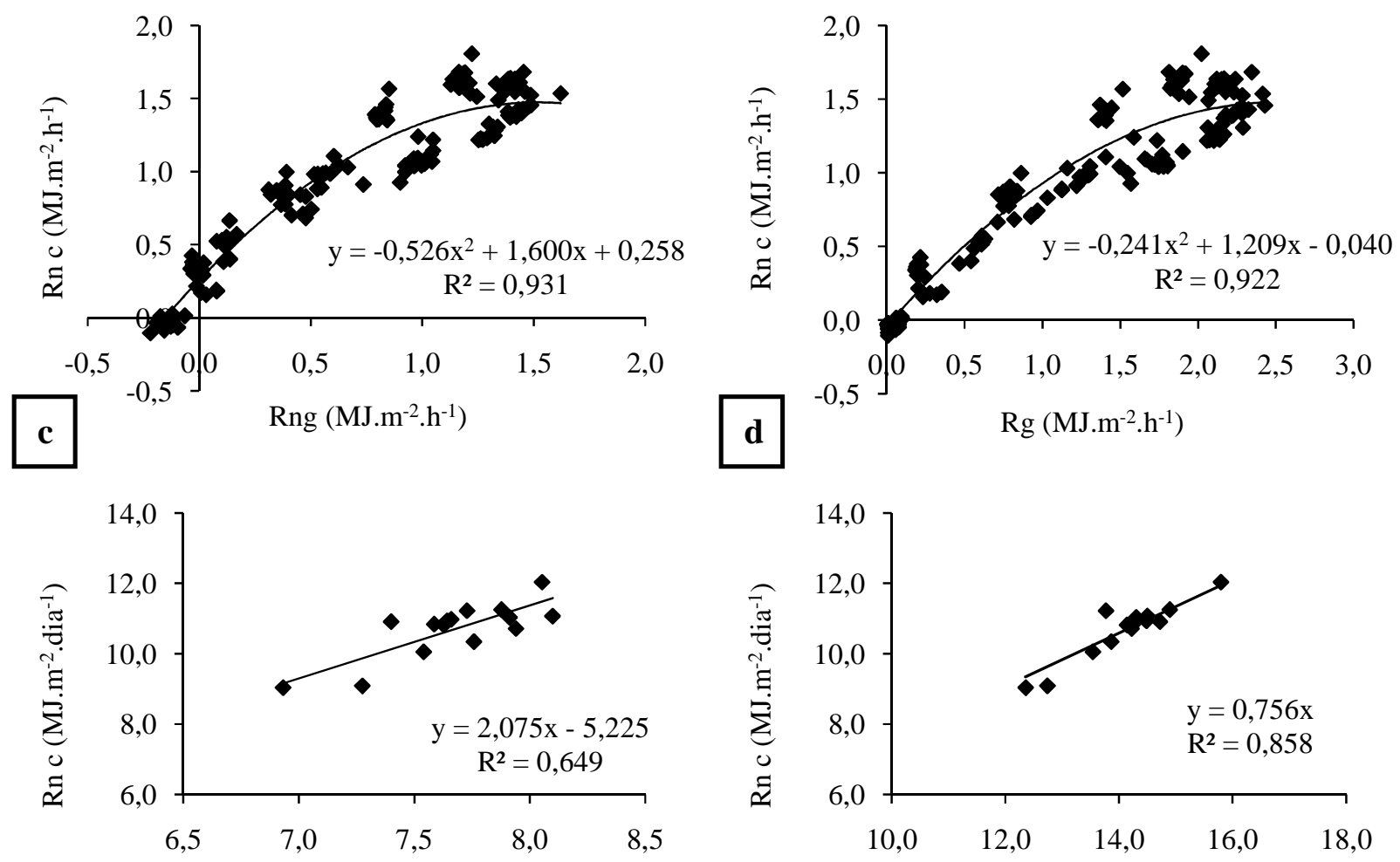

e

Rng (MJ.m $\left.{ }^{-2} \cdot \operatorname{dia}^{-1}\right)$

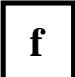

Rg (MJ.m $\left.{ }^{-2} \cdot \operatorname{dia}^{-1}\right)$

Figura 14 - Relações do saldo de radiação de renque de cafeeiro (Rnc) com o saldo de radiação de gramado (Rng) e com a irradiância solar global $(\mathrm{Rg})$ nas escalas de $15 \mathrm{~min}(\mathrm{a}, \mathrm{b})$, horária $(\mathrm{c}, \mathrm{d})$ e diurna $(\mathrm{e}, \mathrm{f})$ para inverno (DJ 198 a 213, exceto dia 205), Piracicaba, 2008

Para a estação de primavera (outubro e novembro) encontrou-se novamente uma relação polinomial de segundo grau para os dados observados na escala de $15 \mathrm{~min}$ e na escala horária (Figuras 15a, 15b, 15c e 15d), mostrando uma alta relação entre as variáveis estudadas, com valores de $\mathrm{R}^{2}$ superiores a 0,9 , apenas notando-se uma pequena dispersão de dados nas correlações horárias, nos valores mais elevados de radiação (Figura 15c e 15d), fato esse que 
indica que a interação da energia com o dossel não apresenta um padrão contínuo ao longo do dia, pois mesmo em condições de energia disponível semelhantes, o saldo de energia observado na copa varia bastante.
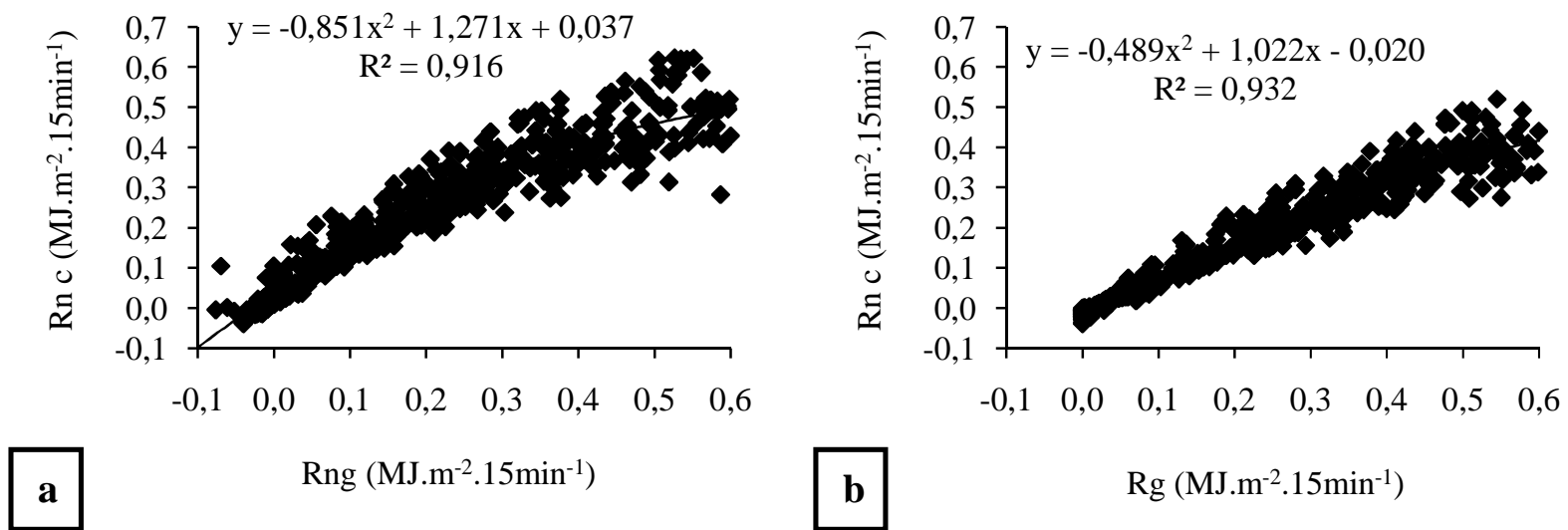

b $\quad \operatorname{Rg}\left(\mathrm{MJ} \cdot \mathrm{m}^{-2} \cdot 15 \mathrm{~min}^{-1}\right)$
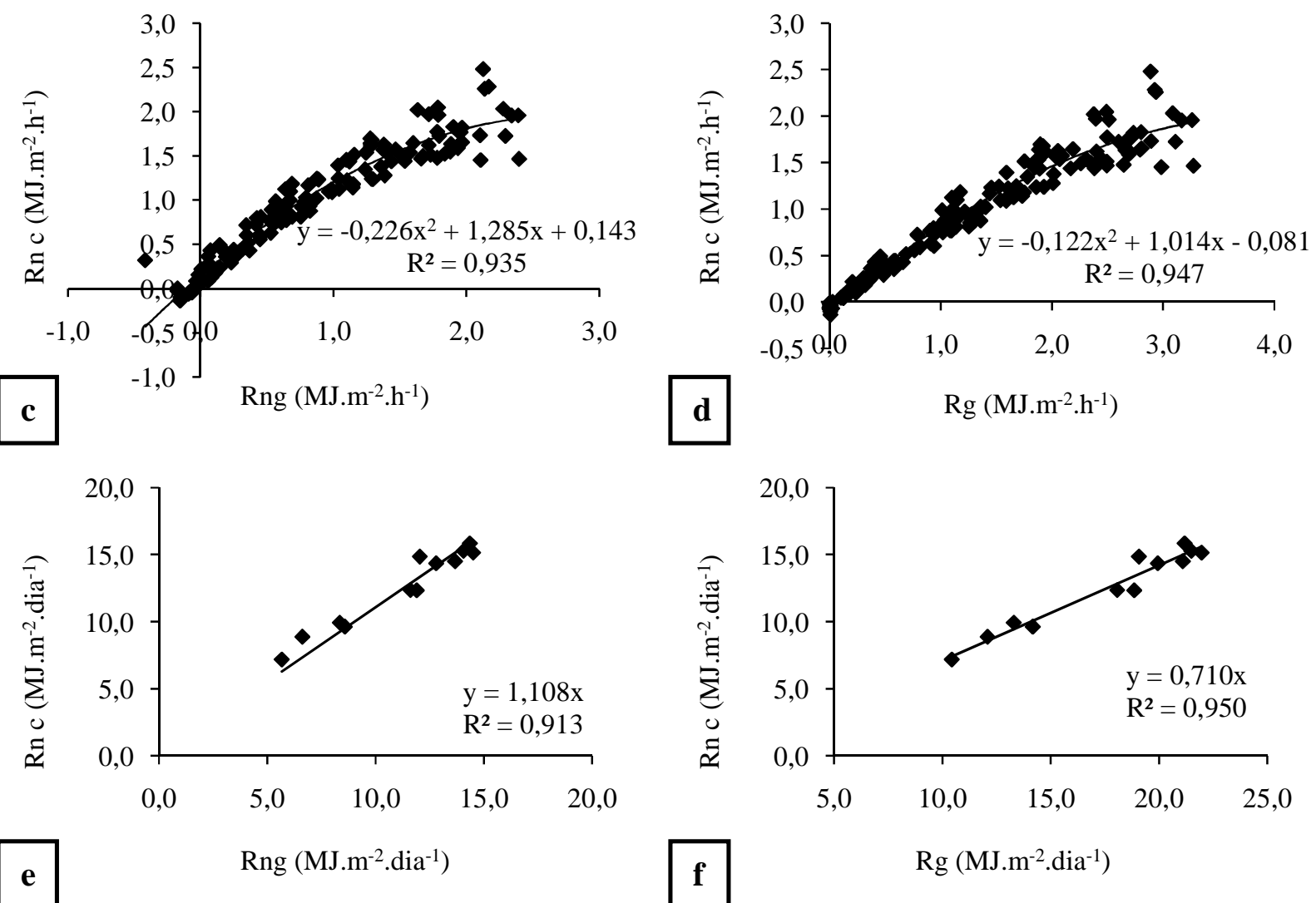

Figura 15 - Relações do saldo de radiação de renque de cafeeiro (Rnc) com o saldo de radiação de gramado (Rng) e com a irradiância solar global $(\mathrm{Rg})$ nas escalas de $15 \mathrm{~min}(\mathrm{a}, \mathrm{b})$, horária $(\mathrm{c}, \mathrm{d})$ e diurna (e,f) para primavera (DJ 274, 275, 298 a 305, 309, 310), Piracicaba, 2008 
$\mathrm{Na}$ escala diurna, as relações lineares entre as variáveis apresentaram elevada concordância, com valores de $\mathrm{R}^{2}$ superiores a 0,9 (Figuras 15 e e $15 f$ ). Na Figura 15e observa-se que o saldo de radiação do renque foi $10 \%$ superior ao observado para gramado e $29 \%$ inferior aos valores de irradiância solar global (Figura 15f), o que corresponde a um aproveitamento de $71 \%$ da energia solar disponível, correspondente ao menor aproveitamento energético entre as estações estudadas. Ocorreu nesta época uma queda acentuada na área foliar (Tabela 1) devido ao secamento de ramos após a colheita devido à grande produtividade das plantas, acarretando maior porosidade das copas e mudanças nas suas propriedades (mudanças na relação folhas/caule e início do aparecimento de folhas jovens).

No verão (fevereiro) as relações seguiram uma tendência linear, embora a dispersão de dados, relativamente alta, tenha sido evidenciada por valores de coeficientes de determinação abaixo de 0,7 , próximo a 0,5 na escala de $15 \mathrm{~min}$ (Figuras 16a e 16b), e na escala horária para a relação com o saldo de radiação de gramado (Figura 16c). Para a correlação com a irradiância solar global, em escala horária, os dados apresentaram menor dispersão, com valor igual a 0,67 , mostrando uma melhora na relação quando se integra os dados em escalas temporais maiores. Isso é evidenciado nas Figuras 16e, 16f, na escala diurna, onde os valores de $\mathrm{R}^{2}$ alcançam valores superiores a 0,9. Esse resultado demonstra que mesmo com uma alta variação e dispersão ao longo das medidas mais pontuais, ao final do dia, tem-se uma compensação, e os valores diários apresentam uma ótima relação entre Rnc com Rng e Rg. Os valores de Rnc foram $20 \%$ superiores aos valores de Rng, e corresponderam a $78 \%$ de energia solar disponível, considerando $\mathrm{Rg}$, valores esses semelhantes aos encontrados para a estação de outono do ano anterior.

Além das relações se mostrarem diferenciadas ao longo do ano, a forma como se apresentam também varia, sendo ora quadrática, ora linear. Uma tendência observada ao longo do ano é que o saldo de radiação das copas variou entre 75 e $80 \%$ da irradiância solar global e foi sempre superior ao saldo de radiação do gramado. A relação com Rng mostra que a estrutura geométrica e a orientação dos renques de cafeeiros leva a um maior aproveitamento na absorção de energia radiante de ondas curtas e ondas longas do que numa superfície plana, como a de um gramado cobrindo totalmente o terreno. 


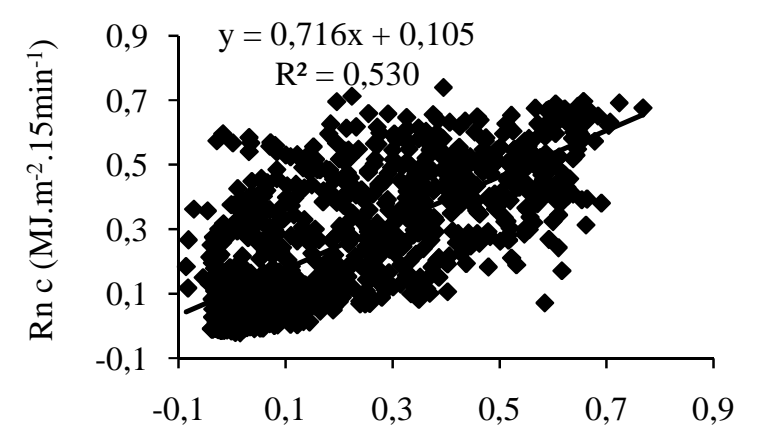

a

Rng (MJ.m-2.15 $\left.\mathrm{min}^{-1}\right)$

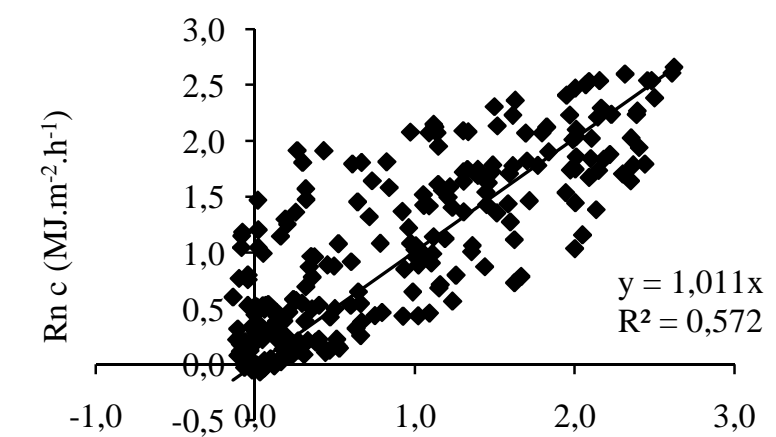

c

Rng $\left(M J \cdot m^{-2} \cdot h^{-1}\right)$

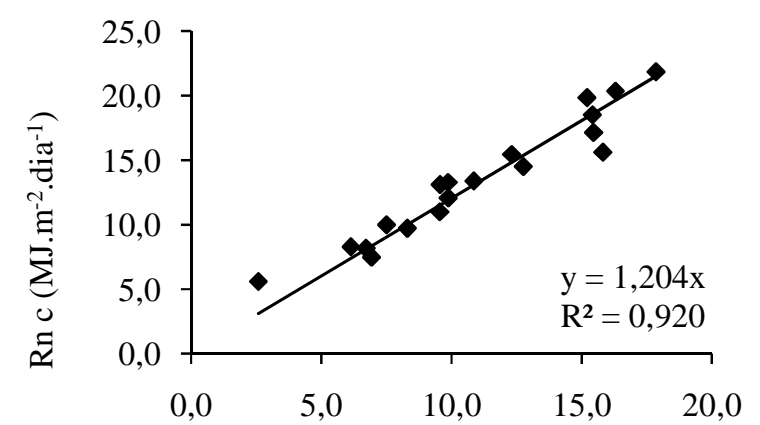

Rng (MJ.m².2.dia $\left.{ }^{-1}\right)$
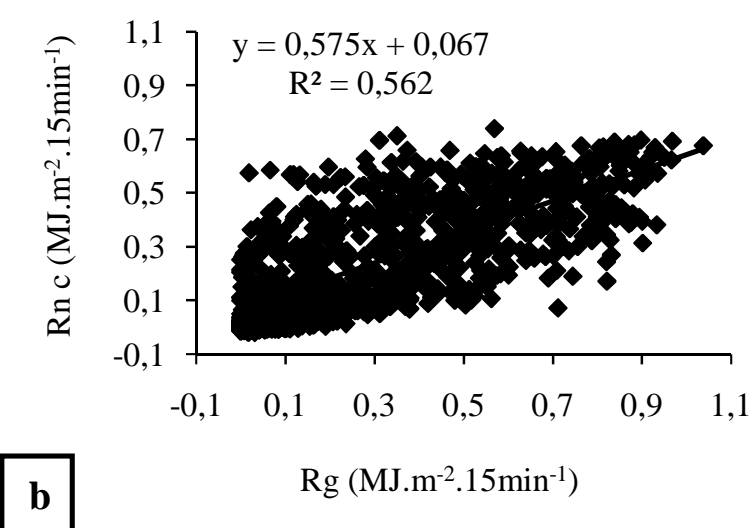

$\operatorname{Rg}\left(\mathrm{MJ} . \mathrm{m}^{-2} .15 \mathrm{~min}^{-1}\right)$
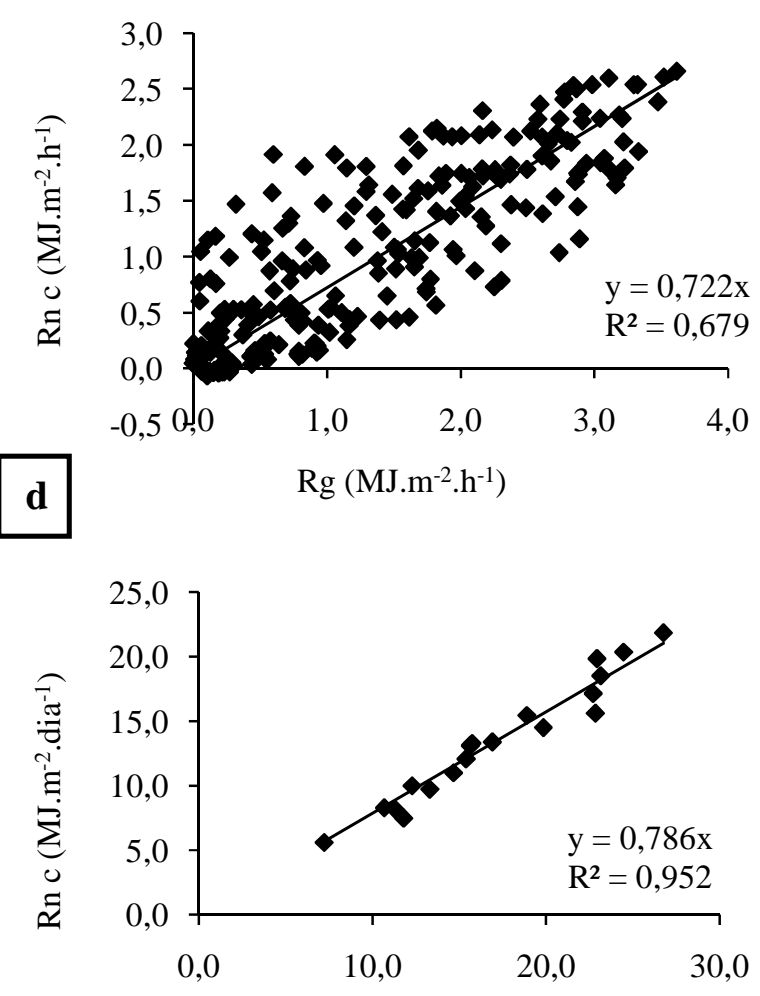

Rg (MJ.m ${ }^{-2} \cdot$ dia $\left.^{-1}\right)$

Figura 16 - Relações do saldo de radiação de renque de cafeeiro (Rnc) com o saldo de radiação de gramado (Rng) e a irradiância solar global $(\mathrm{Rg})$ nas escalas de $15 \mathrm{~min}(\mathrm{a}, \mathrm{b})$, horária $(\mathrm{c}, \mathrm{d})$ e diurna (e,f) para o verão (DJ 32 a 50), Piracicaba, 2009 
Tabela 1 - Área foliar média por árvore (AF), índice de área foliar (IAF) e porosidade média do dossel $(p)$ para cafezal e limeira ácida. IAF determinado por unidade de área de solo na projeção das copas

\begin{tabular}{lrrrr|rrr}
\hline & \multicolumn{4}{c}{ Cafezal } & \multicolumn{3}{c}{ Limeira ácida } \\
& Outono & Inverno & Primavera & Verão & Verão & Outono & Inverno \\
\hline $\mathrm{AF}\left(\mathrm{m}^{2}\right)$ & 14,7 & 11,8 & 9,0 & 9,5 & 58,0 & 60,0 & 50,0 \\
$\mathrm{IAF}$ & 9,0 & 7,5 & 5,9 & 6,4 & 3,1 & 3,0 & 2,5 \\
$P(\%)$ & 7,2 & 9,0 & 11,8 & 11,2 & 10,5 & 10,7 & 11,4 \\
\hline
\end{tabular}

\subsubsection{Limeira ácida}

Relações entre saldo de radiação em renques de limeira ácida e o saldo de gramado e irradiância solar global foram estabelecidas para três estações do ano, buscando estudar como elas variam sazonalmente, em condições de renques com dimensões elevadas. Não foi encontrado na literatura estudos desse tipo em citros e os resultados obtidos demonstram interações diferenciadas daquelas observadas em cafezais, fornecendo subsídios para novas investigações, que comprovem uma relação diferenciada em culturas de grande porte, e na quais as entrelinhas ocupam menor área relativa de terreno que os renques. Relações desse tipo só foram obtidas para plantas cítricas em largo espaçamento, situação de plantas praticamente isoladas (ANGELOCCI et al., 2004; PILAU, 2005) e não em renques.

No verão (dezembro), as relações apresentaram uma grande dispersão de dados para as escalas de $15 \mathrm{~min}$ e horária, apenas demonstrando uma melhoria na escala diurna, com valores de $\mathrm{R}^{2}$ superando o valor de 0,7 , ainda que se ressalte o pequeno conjunto de dados. Nas Figuras 17a e 17 b observa-se que relações entre o saldo de radiação do renque em limeiras ácidas (Rnl) com saldo de radiação de gramado (Rng) e irradiância solar global $(\mathrm{Rg})$ para $15 \mathrm{~min}$ apresentaram uma correlação baixa, com valores de $\mathrm{R}^{2}$ inferiores a 0,5 , situação que se repete para dados integrados na escala horária (Figuras 17c e 17d). Quando integradas na escala diurna, as relações sofrem uma significativa melhora, com diminuição da dispersão, embora o conjunto de dados seja bastante reduzido.

Com base nos valores horários observa-se que Rnl correspondeu a aproximadamente $80 \%$ do Rng, e a aproximadamente 58\% de Rg. Quando se integra para a escala diurna, o Rnl correspondeu de 85 a $110 \%$ de Rng e $63 \%$ de Rg, valores esses não demonstrados, pois o ajuste foi apenas razoável, sendo apresentados somente os valores da regressão linear simples. 

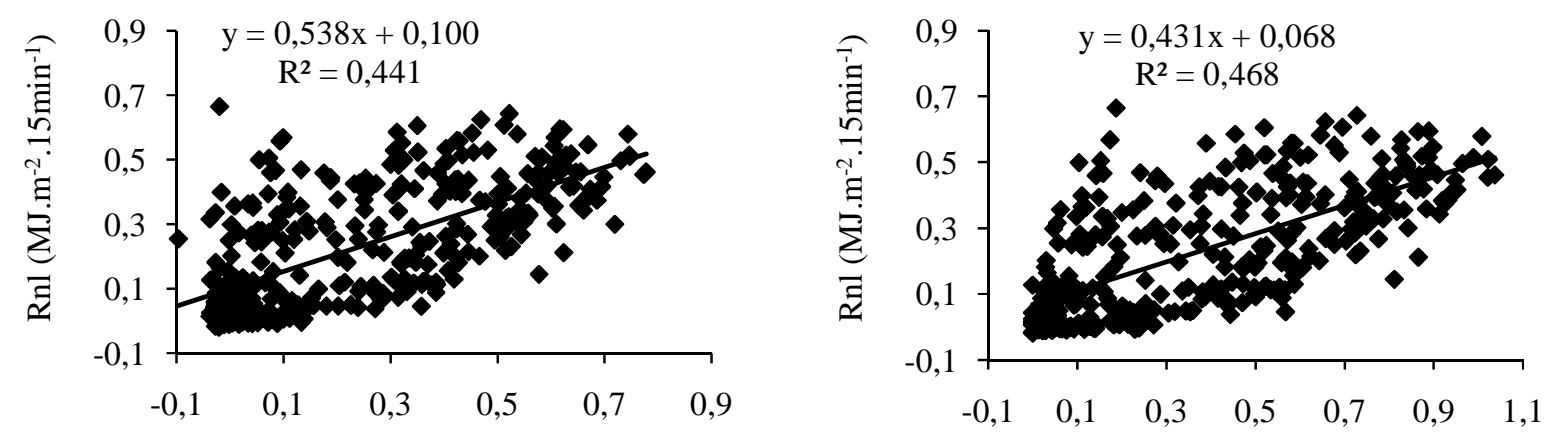

a $\quad$ Rng $\left(\mathrm{MJ} . \mathrm{m}^{-2} \cdot 15 \mathrm{~min}^{-1}\right)$

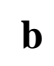

$\operatorname{Rg}\left(\mathrm{MJ} . \mathrm{m}^{-2} .15 \mathrm{~min}^{-1}\right)$
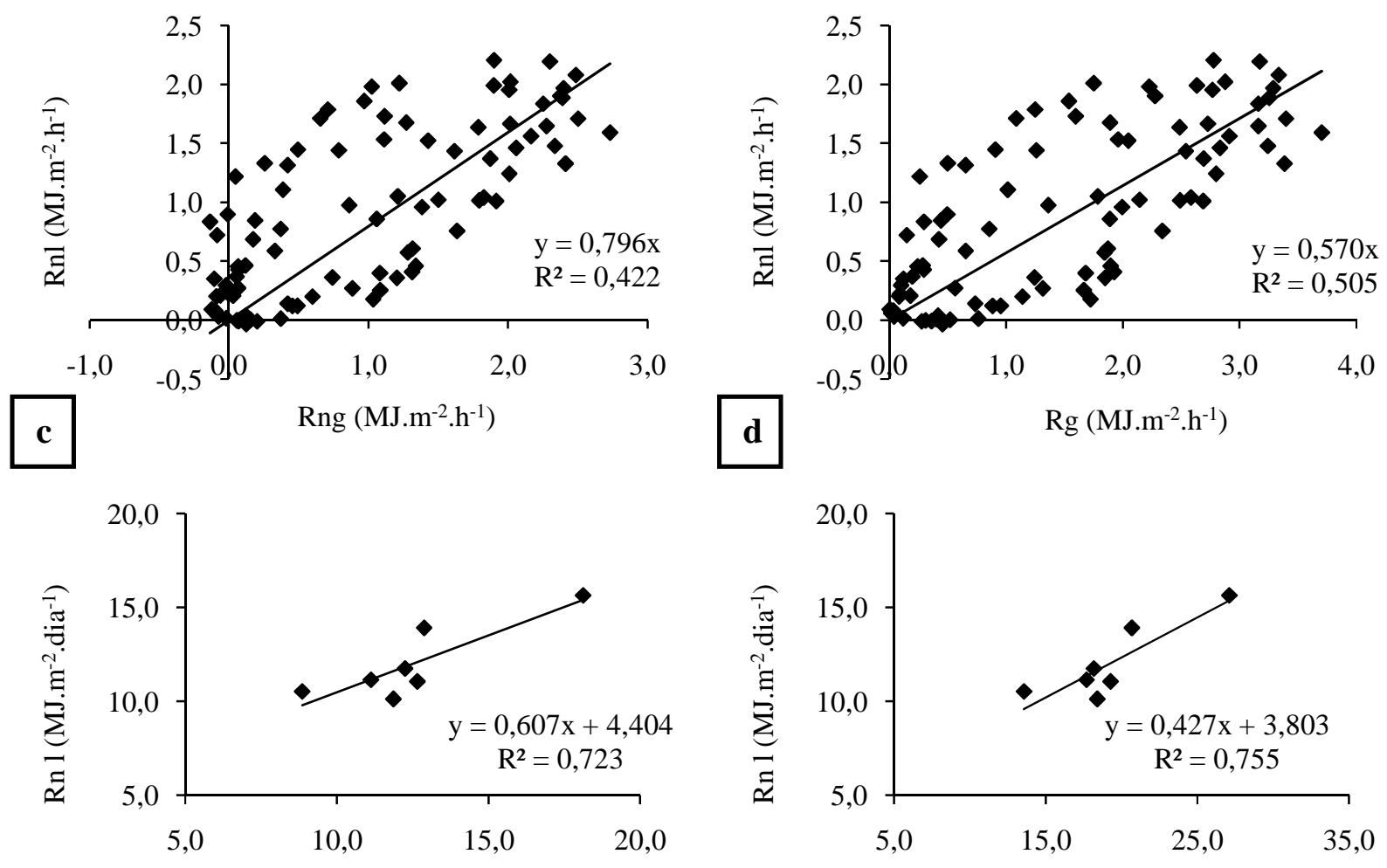

e

Rng (MJ.m $\left.{ }^{-2} \cdot \operatorname{dia}^{-1}\right)$

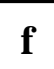

$\operatorname{Rg}\left(M J \cdot m^{-2} \cdot \operatorname{dia}^{-1}\right)$

Figura 17 - Relações do saldo de radiação de renque de limeira ácida (Rnl) com o saldo de radiação de gramado (Rng) e a irradiância solar global $(\mathrm{Rg})$ nas escalas de $15 \mathrm{~min}(\mathrm{a}, \mathrm{b})$, horária $(\mathrm{c}, \mathrm{d})$ e diurna (e,f) para o verão (DJ 354 a 359, 366), Piracicaba, 2008

Esses valores são menores que aqueles encontrados por Angelocci et al. (2004) para limeira ácida "isolada" que corresponderam a $\mathrm{Rnl}=1,46 \mathrm{Rng}$ e $\mathrm{Rnl}=0,9 \mathrm{Rg}$. Como os dados obtidos correspondem à mesma época que aqueles obtidos no trabalho citado, estima-se que a influência das variáveis relativas à radiação seja muito baixa, que a grande diferença nos resultados esteja relacionada ao porte das árvores e sua área foliar e, principalmente, relacionada 
com o sistema de plantio, que neste caso, forma renques, diferentemente de plantas isoladas do estudo de Angelocci et al. (2004), nas quais o regime radiativo é diferenciado e as interações particulares.
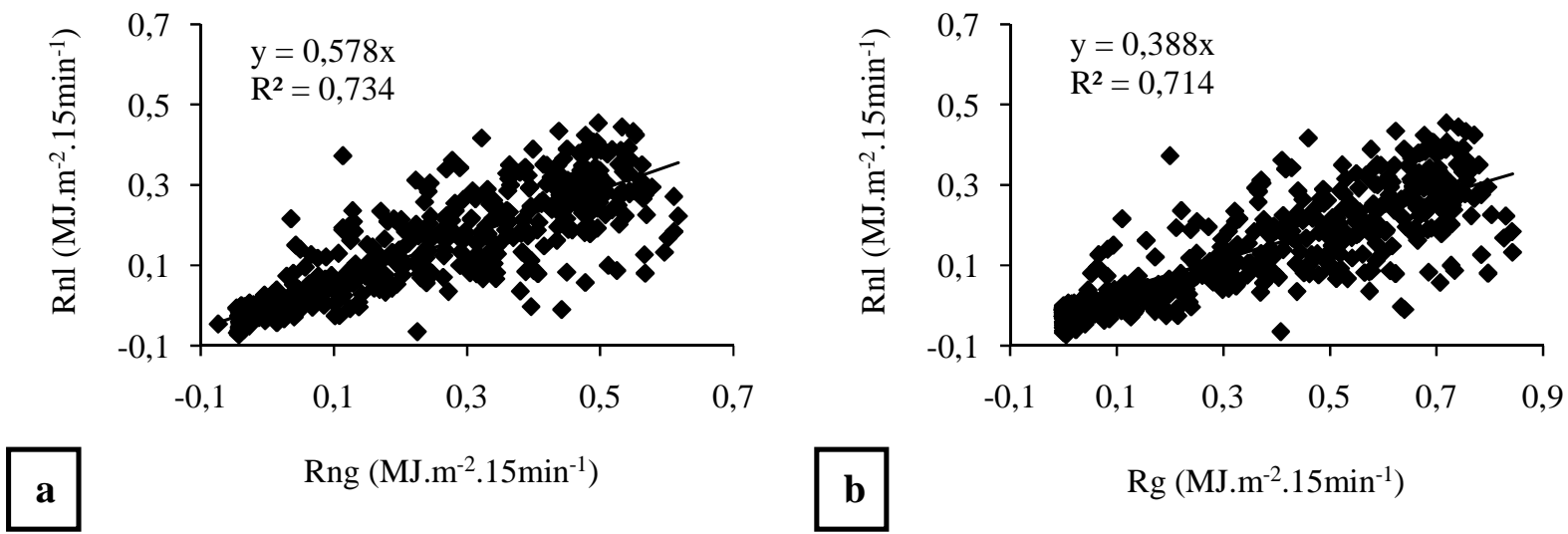

$\mathbf{b}$

$\operatorname{Rg}\left(\mathrm{MJ} . \mathrm{m}^{-2} .15 \mathrm{~min}^{-1}\right)$
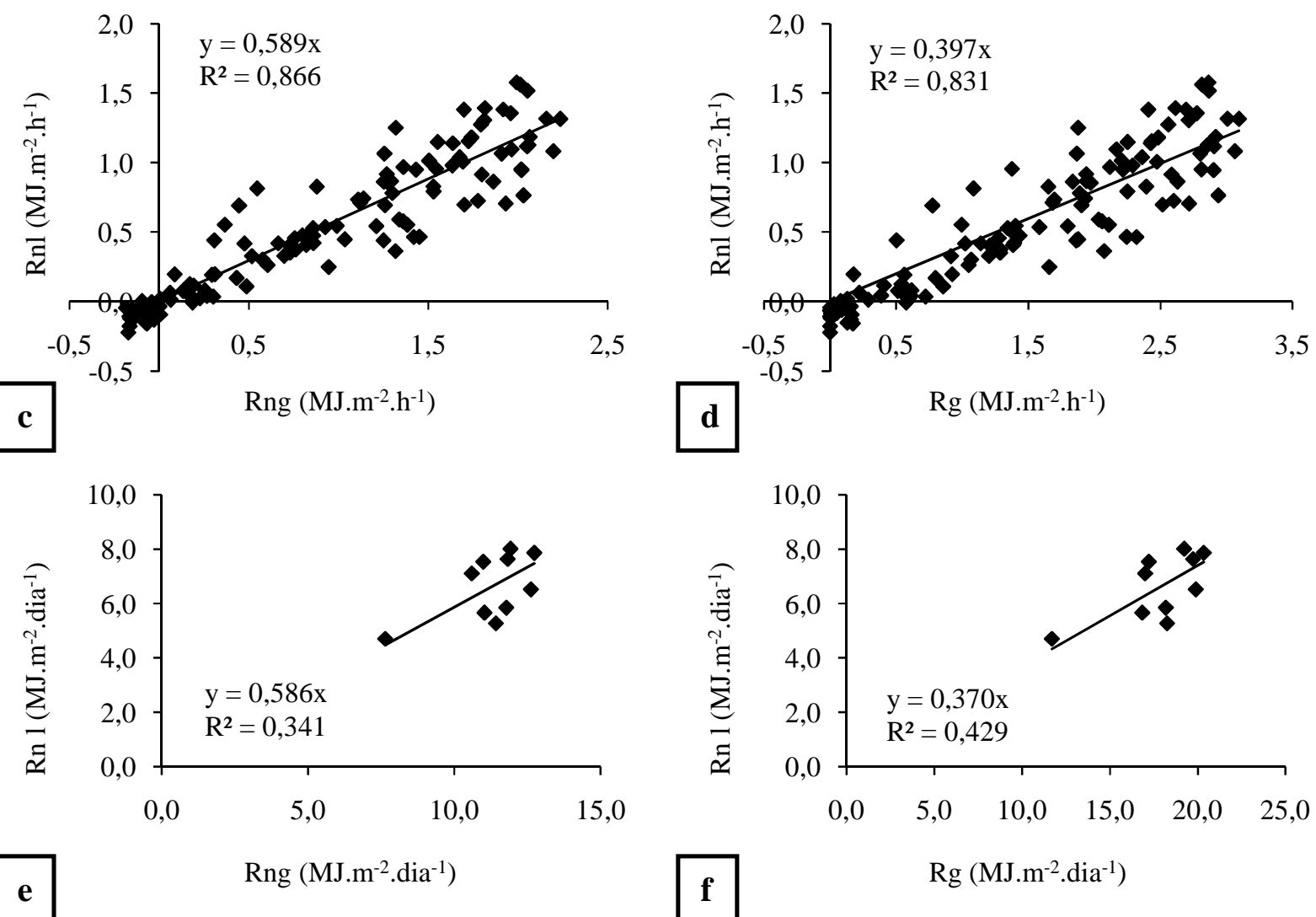

Figura 18 - Relações do saldo de radiação de renque de limeira ácida Tahiti (Rnl) com o saldo de radiação de gramado (Rng) e a irradiância solar global $(\operatorname{Rg})$ nas escalas de $15 \mathrm{~min}(\mathrm{a}, \mathrm{b})$, horária $(\mathrm{c}, \mathrm{d})$ e diurna (e,f) para o outono (DJ 82 a 87, 99 a 102), Piracicaba, 2009 
Para o outono, as relações obtidas para as escalas de $15 \mathrm{~min}$ e horária, apresentaram boa concordância, observados os valores de $\mathrm{R}^{2}$ superiores a 0,7 , e um ajuste linear com passagem pela origem dos eixos (Figuras 18a, 18b, 18c e 18d). O Rnl, na escala horária, representou aproximadamente $60 \%$ de Rng e 40\% de Rg, com coeficientes de determinação de 0,87 e 0,83, respectivamente (Figuras 18c e 18d). Na escala diurna (Figuras 18e e 18f), o conjunto de dados mostrou-se bastante disperso, não apresentando ajuste satisfatório para nenhuma forma de análise e com valores de $\mathrm{R}^{2}$ ao redor de 0,4 ou inferior, no caso da relação entre Rnl e Rng (Figura 18e), mas deve-se ressaltar o pequeno número e a pequena amplitude de valores dos dados utilizados no ajuste.

Embora os dados tenham apresentado um melhor ajuste nas escalas de 15min e horária, quando integrados para a escala diurna a concordância e os próprios valores ficaram muito aquém dos esperados para esta época do ano. Deve-se salientar que para este local, essa época do ano é bastante particular, apresentando longos períodos com nebulosidade, enquanto a freqüência de dias chuvosos dificulta os estudos. Embora para os dias de análise não tenha ocorrido chuvas, o período de coleta não foi contínuo e alguns danos foram visualizados sobre as cúpulas de proteção dos radiômetros superiores. Isso pode ter sido responsável pelos baixos valores de Rnl do período, já que a influência dos ventos e o acúmulo de umidade na placa sensora são fontes de erro podem ter influenciado grandemente as medidas e contribuindo para o aumento de sua variabilidade.

Os dados apresentados na Figura 19 são referentes ao inverno. Para esta estação, tanto a escala de $15 \mathrm{~min}$, quanto à horária e a diurna apresentaram altos coeficientes de determinação, com valores acima de 0,9 , e baixa dispersão de dados. Os dados de saldo de radiação do renque corresponderam a 1,45 vezes o saldo de gramado, e $72 \%$ da irradiância solar global na escala diurna (Figuras 19e e 19f). Ambas as escalas admitiram um ajuste linear simples, passando pela origem dos eixos.

As relações apresentadas indicam a possibilidade de estimativa do saldo de radiação do dossel vegetativo das linhas de plantio em cafezais e em pomares, a partir das medidas de irradiância solar global e saldo de radiação sobre gramado, mas confirmam a sazonalidade das relações já observadas em estudos anteriores (ANGELOCCI et al., 2004; PILAU, 2005). Além do efeito da posição aparente do Sol em relação ao alinhamento dos renques, pesa nessas medidas o efeito da área foliar e a porosidade das copas. Isso torna tais relações mais indicadas para 
explicar o efeito dessas variáveis sobre Rn de renques, mas o valor preditivo das mesmas não se torna universal pela especificidade das relações com aquelas características da cobertura vegetal.
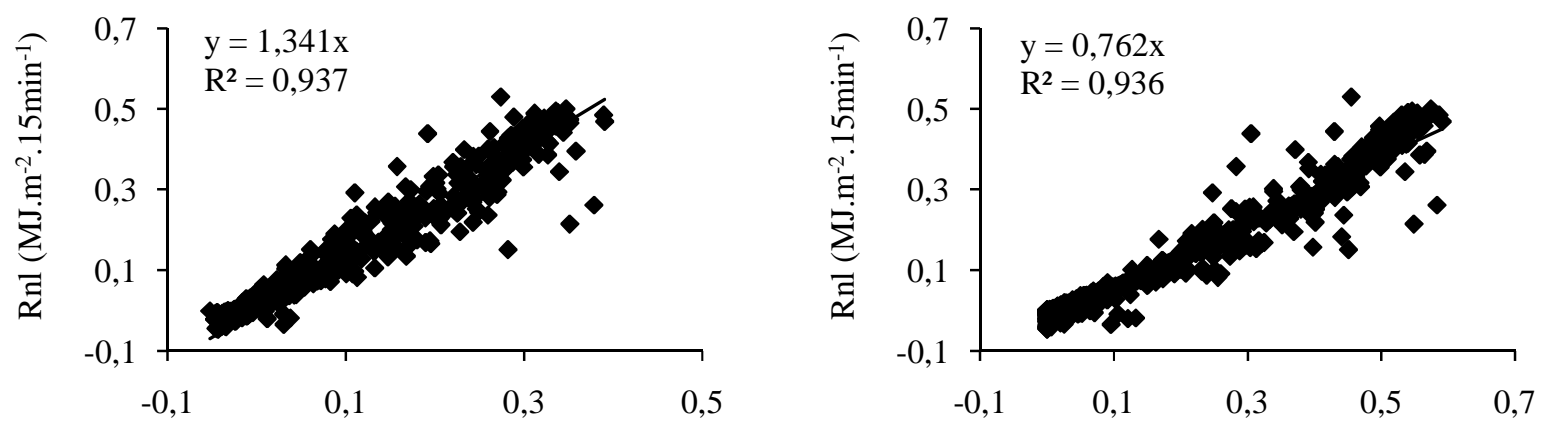

$\mathbf{a} \quad \operatorname{Rng}\left(\mathrm{MJ} \cdot \mathrm{m}^{-2} \cdot 15 \mathrm{~min}^{-1}\right)$

b $\quad \operatorname{Rg}\left(\mathrm{MJ} \cdot \mathrm{m}^{-2} \cdot 15 \mathrm{~min}^{-1}\right)$
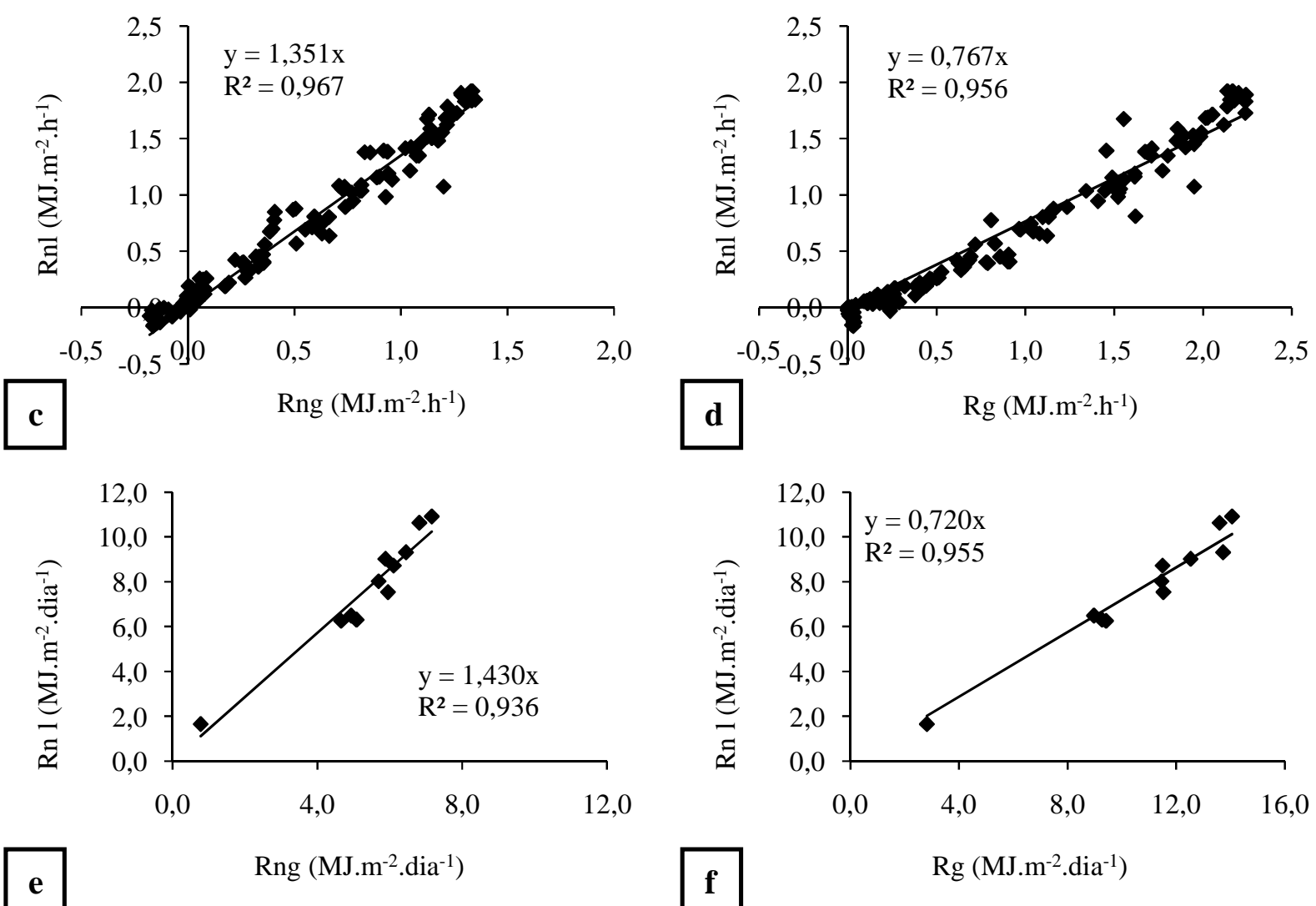

$\mathbf{e}$ Rng $\left(\mathrm{MJ} \cdot \mathrm{m}^{-2} \cdot \operatorname{dia}^{-1}\right)$

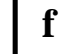

Figura 19 - Relações do saldo de radiação de renque de limeira ácida Tahiti (Rnl) com o saldo de radiação de gramado (Rng) e a irradiância solar global $(\operatorname{Rg})$ nas escalas de $15 \mathrm{~min}(\mathrm{a}, \mathrm{b})$, horária $(\mathrm{c}, \mathrm{d})$ e diurna $(\mathrm{e}, \mathrm{f})$ para o inverno (DJ 172 a 182), Piracicaba, 2009 


\subsection{Estimativa do saldo de radiação em renques pelo uso da lei de Beer}

\subsubsection{Cafezal}

As Figuras 20 e 21 apresentam as relações nas escalas de 15min, horária e diurna entre o saldo de radiação estimado pela Lei de Beer (Rn_Beer) para um cafezal para as quatro estações do ano e o saldo de radiação medido pelo sistema integrador (Rnc). Os valores de saldo de radiação são expressos por unidade de terreno na projeção das copas.

Uma das limitações ao uso dessa lei está no pressuposto que ela apenas é valida para situações onde o IAF seja inferior a 5,5. Esta situação pode ser alcançada por algumas culturas de interesse agrícola, como o cafezal por exemplo. Nesse estudo não foi verificada limitação ao uso da Lei de Beer em função dos valores de IAF medidos em cada estação do ano (Tabela 1), havendo-se de considerar que o IAF foi calculado por unidade de área de terreno na projeção da copa.

Para as estações de outono, inverno e primavera, as correlações na escala de $15 \mathrm{~min}$ apresentaram melhores ajustes por equações polinomiais de segundo grau, enquanto para o verão a dispersão foi elevada e o melhor ajuste foi obtido por equação linear simples. Quando integrados os dados para a escala horária, as correlações, mesmo com uma leve queda no coeficiente de determinação, seguem equações lineares simples. Na escala diurna, os valores de $\mathrm{R}^{2}$ voltam a ficar elevados, em torno de 0,97 , excetuando-se o inverno, onde a dispersão dos dados foi mais evidente.

Os dados de saldo de radiação de renque calculados com o uso da Lei de Beer apresentaram em média, pequena subestimativa em todas as estações do ano, exceto a de inverno, na qual o coeficiente encontrado foi unitário. A maior subestimativa foi encontrada na primavera, em torno de $3 \%$ do valor medido a campo. A variação nos coeficientes das equações ao longo do ano evidencia a variação que ocorre no regime radiativo nas diferentes estações. Fatores como a declinação solar, intensidade de radiação, área foliar, propriedades óticas da folha e do solo, umidade do ar e nebulosidade são fatores que variam muito ao longo do ano e influenciam fortemente o regime radiativo de uma cultura.

Como observado por Marin (2003) e Pilau (2005), a utilização do modelo da lei de Beer mostrou-se uma alternativa muito boa para a estimativa do saldo de radiação do dossel vegetativo 
da linha de plantio em um cafezal plantado em forma de renques, na escala horária e de 24 horas, pois as relações foram lineares e com altos valores de $\mathrm{R}^{2}$. A exceção a esse bom desempenho do modelo foi na escala horária (além da escala de $15 \mathrm{~min}$ ) para o verão.
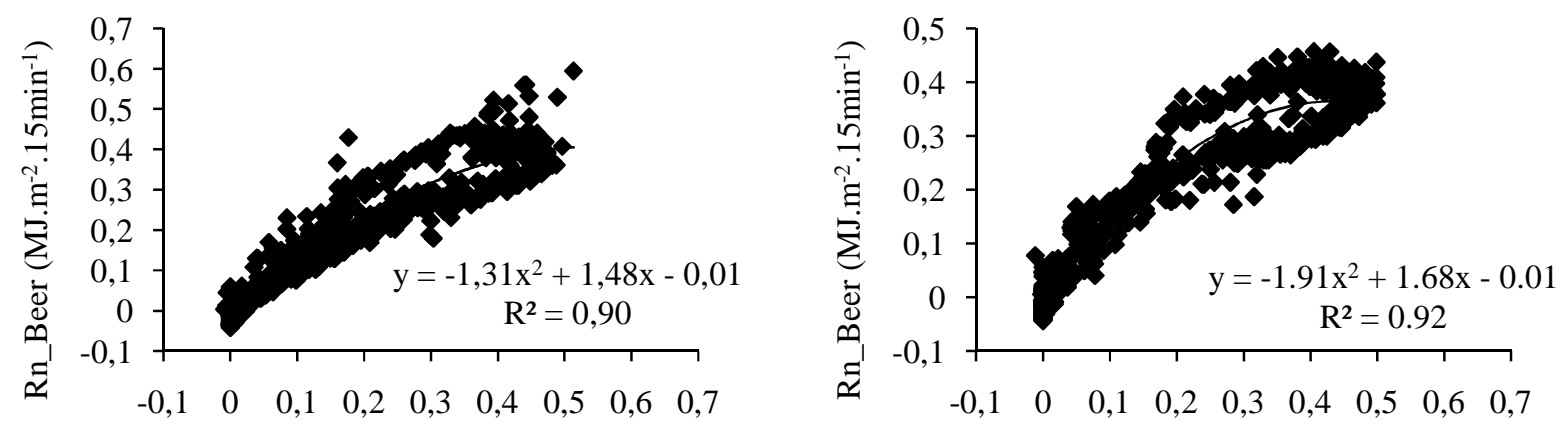

\section{$\mathbf{a}$}

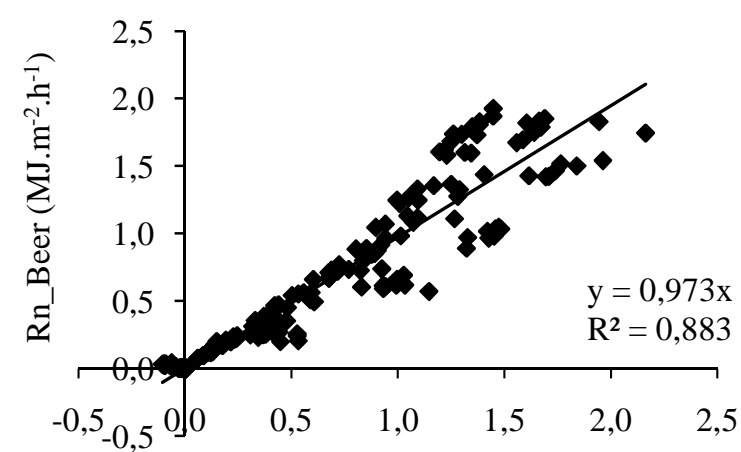

c

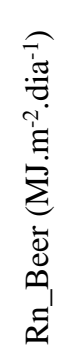

e

Rnc (MJ.m-2 $\left.15 \mathrm{~min}^{-1}\right)$

$$
\text { Rnc }\left(M J \cdot m^{-2} \cdot h^{-1}\right)
$$

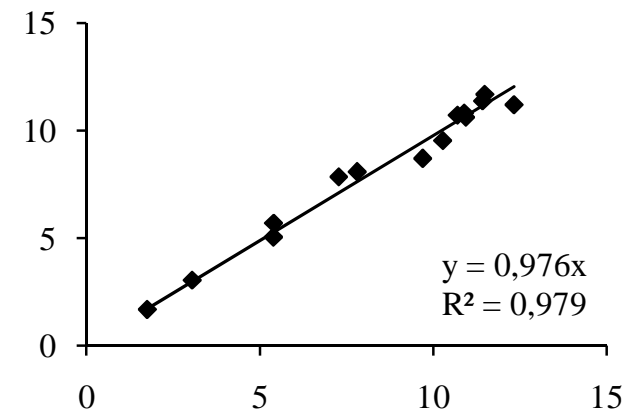

Rnc (MJ.m². dia $\left.^{-1}\right)$

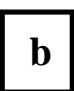

Rnc (MJ.m-2 $\left.{ }^{-2} 15 \mathrm{~min}^{-1}\right)$
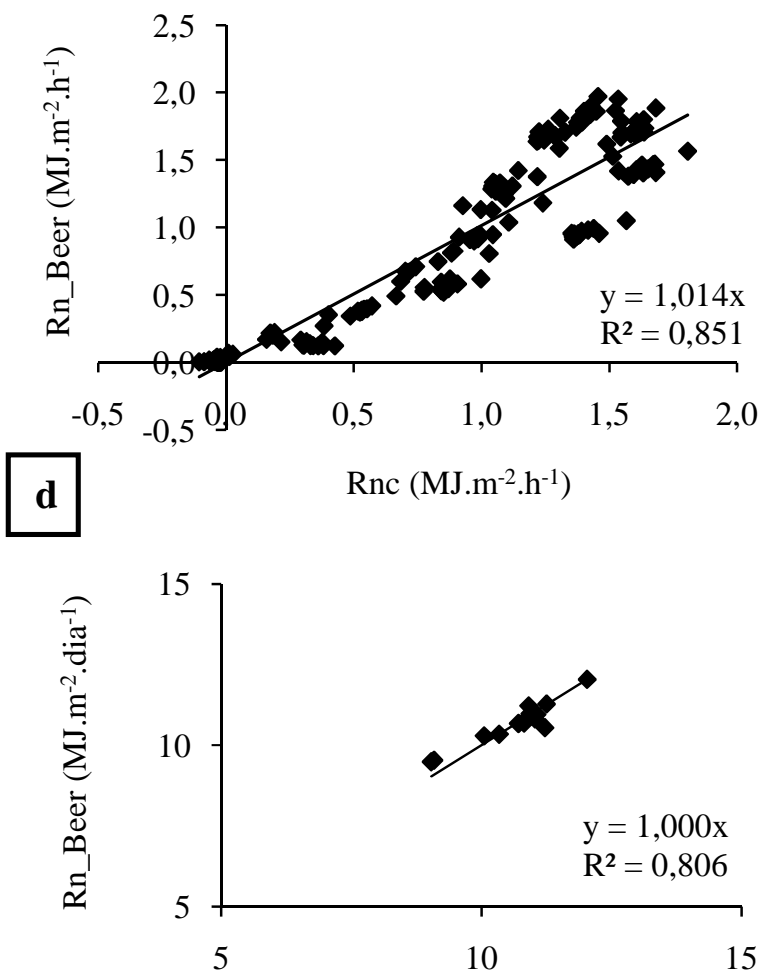

Rnc $\left(M J \cdot m^{-2} \cdot\right.$ dia $\left.^{-1}\right)$

Figura 20 - Relações do saldo de radiação medido (Rnc) com o estimado para o cafezal pela Lei de Beer nas escalas de $15 \mathrm{~min}$, horária e diurna para outono (a,c,e) e inverno (b,d,f), Piracicaba, 2008 
Os resultados obtidos no presente estudo no cafezal são mais completos do que os obtidos anteriormente por Marin (2003) em cafezal "Mundo Novo" no mesmo local e por Pilau (2005) no mesmo cafezal usado no presente estudo, em estágio de menor crescimento. Os mesmos autores somente fizeram estudos em uma estação do ano.
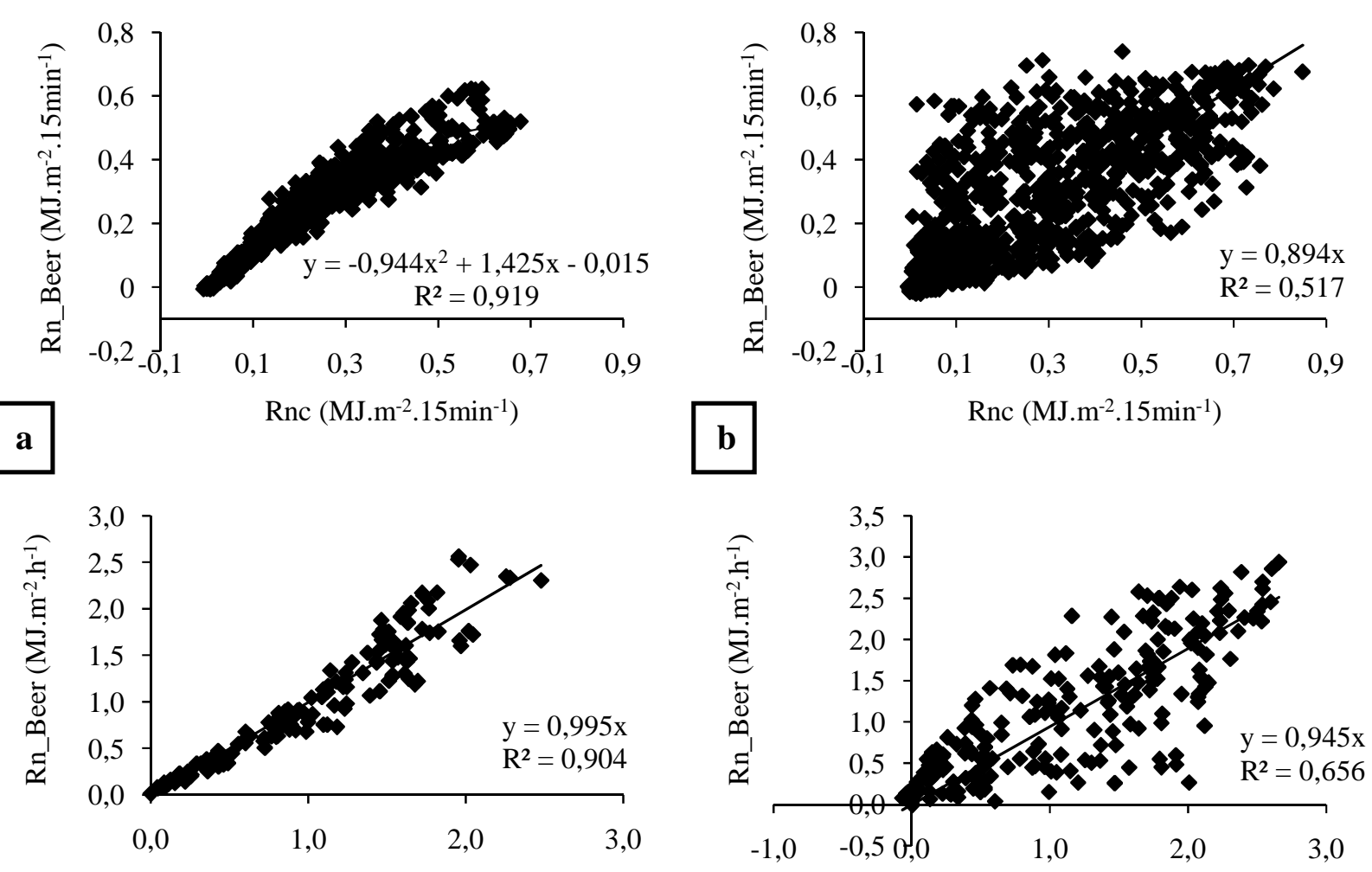

c $\quad \operatorname{Rnc}\left(\mathrm{MJ} \cdot \mathrm{m}^{-2} \cdot \mathrm{h}^{-1}\right)$
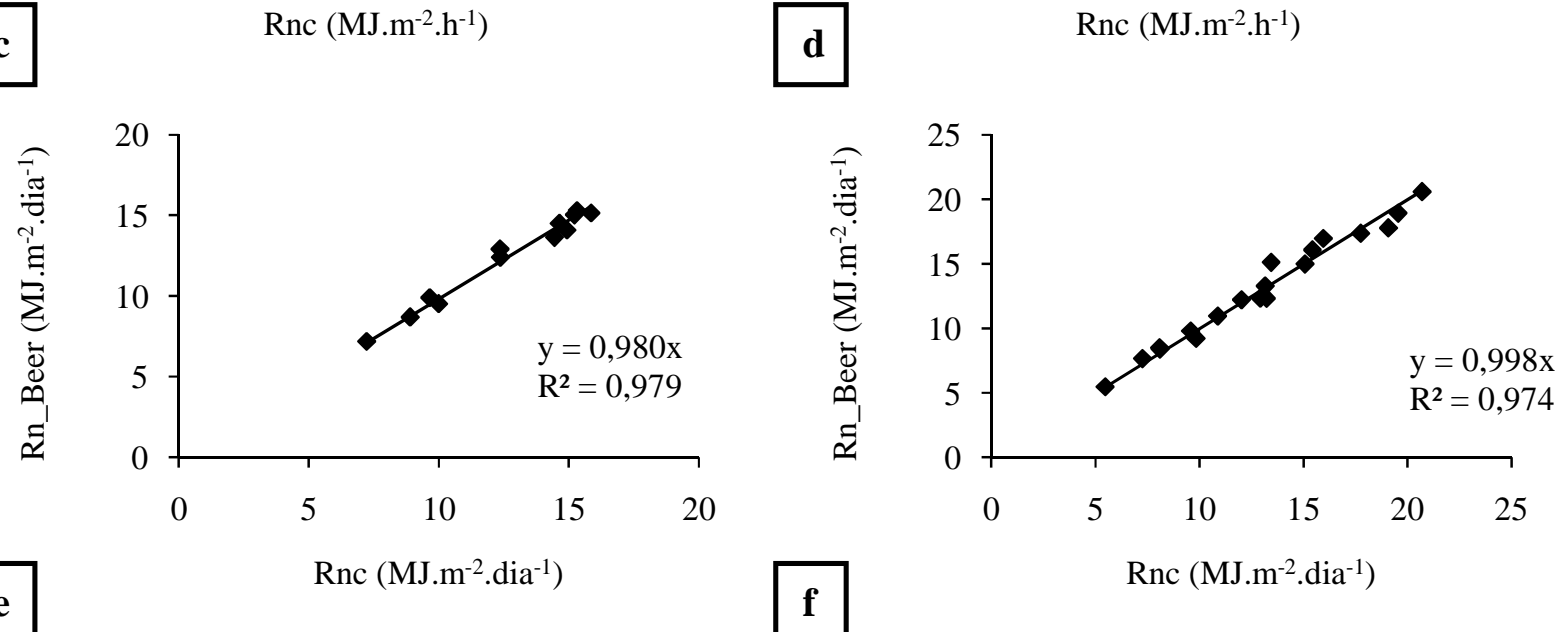

e

Rnc $\left(\mathrm{MJ} \cdot \mathrm{m}^{-2} \cdot \mathrm{dia}^{-1}\right)$

Figura 21 - Relações do saldo de radiação medido (Rnc) com o estimado para o cafezal pela Lei de Beer nas escalas de 15min, horária e diurna para as estações de primavera de 2008 (a,c,e) e verão 2009(b,d,f), Piracicaba 
Apesar do desempenho ruim nas escalas de tempo de $15 \mathrm{~min}$ e horária no verão, o modelo pode ser usado para estimativas de Rnc em cafezais de plantio em renques, principalmente quando os valores são integrados para períodos maiores, como diurnos e diários, constatação esta bastante interessante, por se tratar de um modelo simples, sem grandes exigências quanto às variáveis de entrada, sendo a mais complexa, a determinação da área foliar e uma variável chave, o coeficiente de atenuação k. Uma discussão adicional com uso de indicadores estatísticos é feita no item 4.8 para o modelo de Beer e para os outros dois, nas duas coberturas vegetais.

\subsubsection{Limeira ácida}

Nas Figuras 22 e 23 estão apresentadas as relações entre o saldo de radiação do renque e os valores estimados pelo uso da Lei de Beer, nas escalas de $15 \mathrm{~min}$, horária e diurna para um renque de limeira ácida. $\mathrm{O}$ estudo foi realizado ao longo de três estações do ano. O índice de área foliar, assim como na cultura do café, apresentou valores que podem ser considerados não restritivos ao emprego do modelo (Tabela 1). O desempenho foi diferenciado entre as estações do ano, mostrando maior dispersão dos dados em relação aos obtidos na aplicação do modelo no cafezal, conforme verificados pelos valores de $\mathrm{R}^{2}$ obtidos.

Nas Figuras 22a, 22c e 22e encontram-se as correlações para o mês de dezembro. Em ambas as escalas, os dados ajustaram-se às regressões lineares simples, mas com uma dispersão de dados elevada, ocorrendo uma melhora na escala diurna. Na escala diurna, os dados estimados pela lei de Beer foram $31,5 \%$ superiores aos dados medidos, com $\mathrm{R}^{2}$ igual a 0,714 , diferentemente do que foi observado para a cultura do cafeeiro, onde os dados obtidos pelo uso da lei subestimavam os dados observados e a dispersão de dados foi bem menor. Nas Figuras 22b, 22d e 22f são apresentadas as relações para a estação de outono nas escalas de $15 \mathrm{~min}$, horária e diurna. Assim como na estação de verão, em ambas as escalas, a relação mostrou-se linear simples, mas observa-se que nas escalas de 15 min e horária ocorreu uma menor dispersão de dados. Diferentemente, para a escala diurna, o ajuste foi pior nesta estação. Quando os valores foram integrados nesta escala (Figura 22f), a concordância diminuiu abruptamente, mas a tendência dos dados se manteve, seguindo uma reta. Isto porque a variação nos dados medidos foi inferior àquela dos dados calculados, enquanto a relação obtida na relação foi de 1,14 acrescido de um intercepto de 5,89 MJ.m $\mathrm{m}^{-2} \cdot \mathrm{dia}^{-1}$, de modo que na gama de valores observada, os valores estimados a partir da lei de Beer resultaram praticamente o dobro daqueles medidos. 

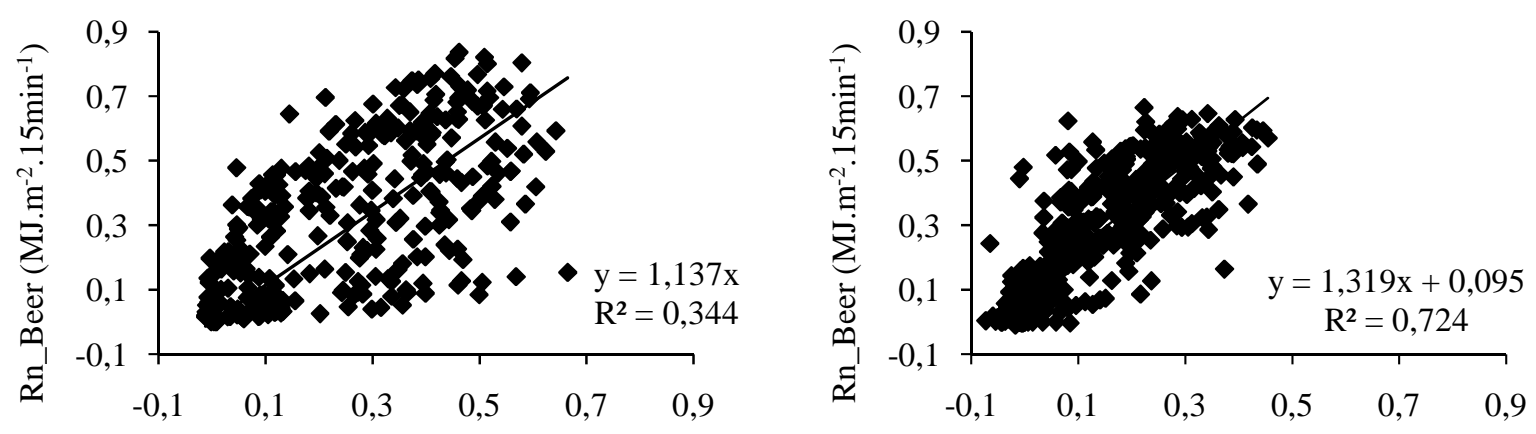

$\mathbf{a}$

Rnl (MJ.m-2.15 $\left.\mathrm{min}^{-1}\right)$

b $\quad$ Rnl $\left(\mathrm{MJ} \cdot \mathrm{m}^{-2} \cdot 15 \mathrm{~min}^{-1}\right)$
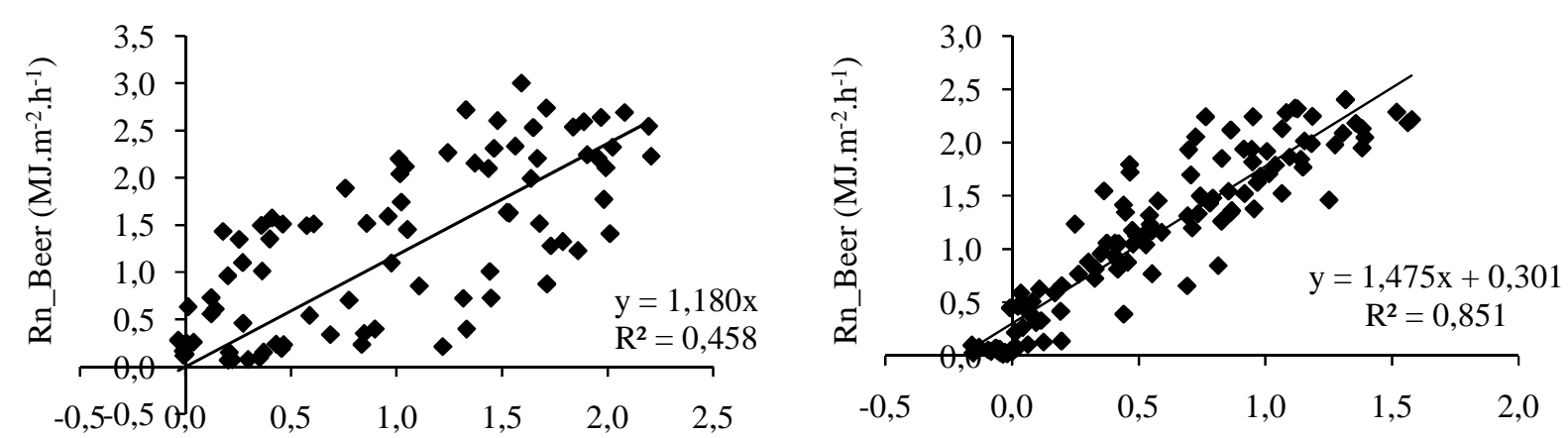

c

Rnl $\left(\mathrm{MJ} \cdot \mathrm{m}^{-2} \cdot \mathrm{h}^{-1}\right)$
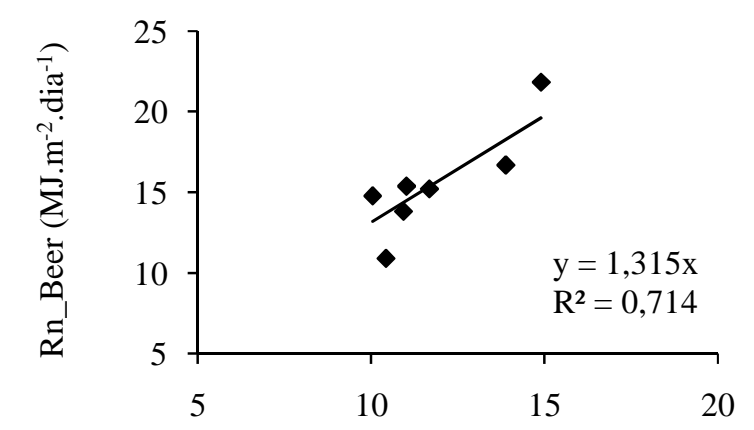

d

Rnl (MJ.m-2.h'-1)
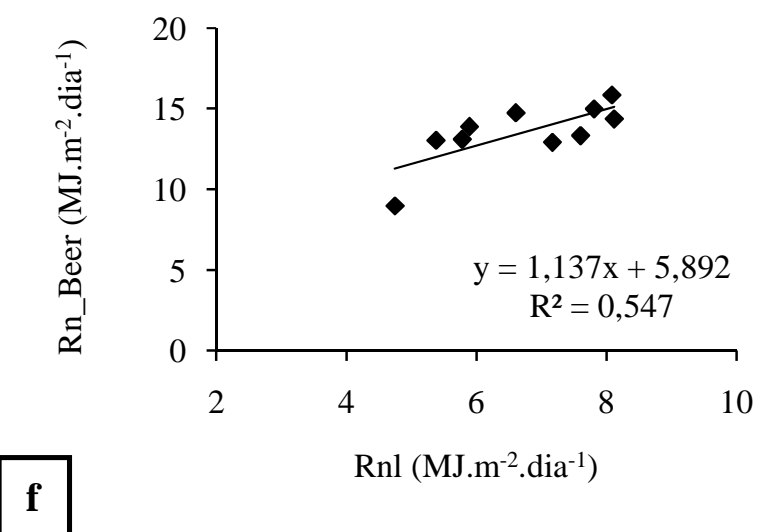

Rnl (MJ.m². dia $\left.^{-1}\right)$

e

Rnl (MJ.m'-2.dia-1)

Figura 22 - Relações do saldo de radiação medido (Rnl) com o estimado para o cafezal pela Lei de Beer nas escalas de 15min, horária e diurna para o verão de 2008 (a,c,e) e o outono de 2009(b,d,f), Piracicaba

Na Figura 23 estão as relações de inverno para as escalas de 15min, horária e diurna, entre o saldo de radiação medido e o estimado pela lei de Beer. Ao contrário dos casos anteriores, para esta estação o ajuste foi muito bom, com baixa dispersão dos dados e ajuste polinomial de segundo grau para os dados na escala de $15 \mathrm{~min}$. Embora o valor decrescesse na escala diurna, $\mathrm{R}^{2}$ foi superior a 0,9 , sendo o melhor ajuste ao longo do ano. Diferentemente das demais estações 
estudadas, os valores estimados pelo uso da Lei de Beer na escala diurna subestimaram os valores medidos para esta estação em torno de $13 \%$, seguindo a tendência das relações obtidas para o cafezal.
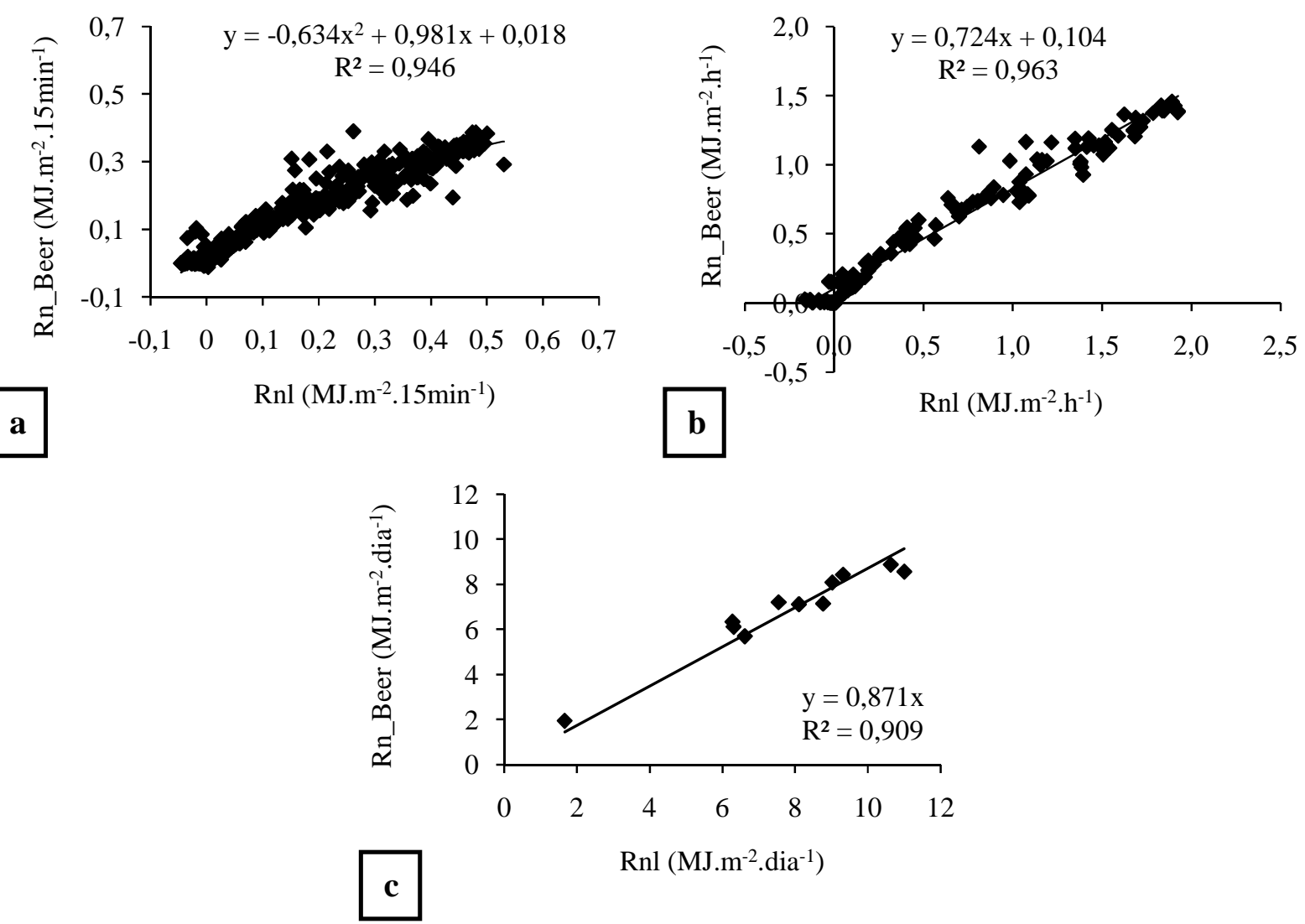

Figura 23 - Relações do saldo de radiação medido (Rnl) com o estimado para o cafezal pela Lei de Beer nas escalas de 15min, horária e diurna para a estação de inverno (a,b,c), Piracicaba, 2009

\subsection{Desempenho do modelo proposto por Pilau (2005) para estimativa do saldo de radiação} das copas

\subsubsection{Cafezal}

As Figuras 24 e 25 mostram as relações entre valores estimados e observados em três escalas de tempo (15min, horária e diurna) para as quatro estações do ano para o trecho de linha estudado no cafezal. Na Figuras 24a, 24c e 24e estão as relações obtidas para o outono de 2008 
nas diferentes escalas propostas. Pode-se observar que em ambas ocorre ajuste linear simples com coeficientes de determinação elevados, acima de 0,9 e superestimativa em torno de $4 \%$ com relação aos valores observados.
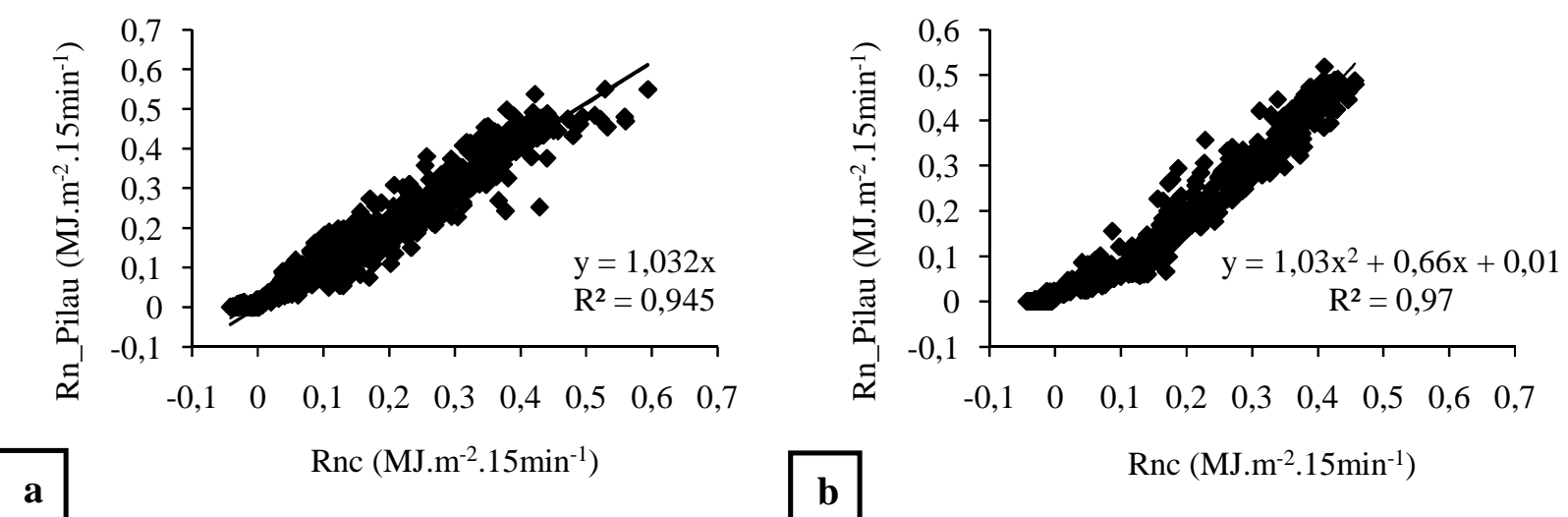

Rnc (MJ.m-1 $\left.15 \mathrm{~min}^{-1}\right)$

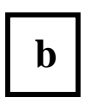

Rnc $\left(\mathrm{MJ} . \mathrm{m}^{-2} .15 \mathrm{~min}^{-1}\right)$
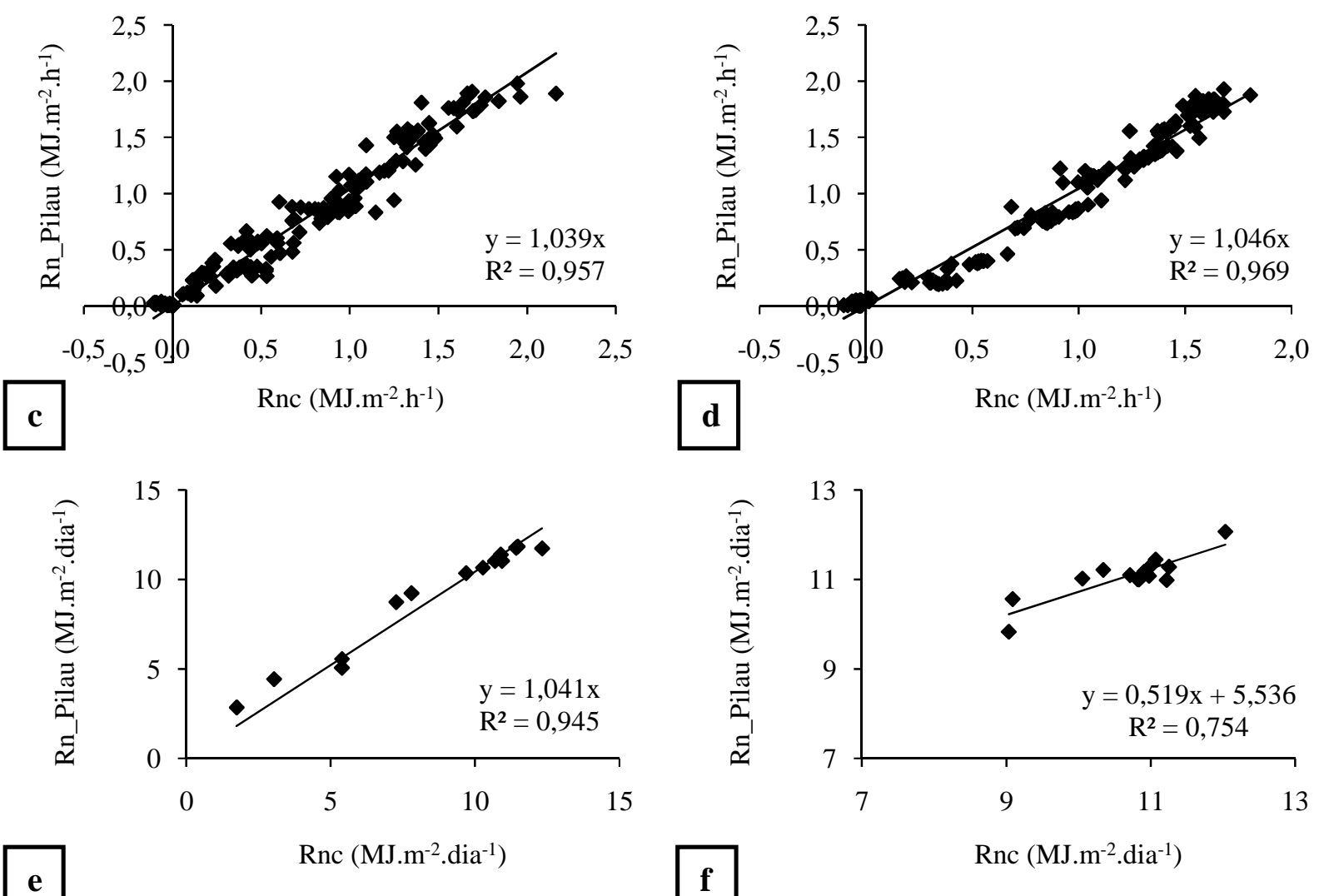

Figura 24 - Relações do saldo de radiação medido (Rnc) com o estimado para o cafezal pelo modelo proposto (PILAU, 2005) nas escalas de 15min, horária e diurna para o outono (a,c,e) e o inverno (b,d,f), Piracicaba, 2008 
Para o inverno (Figuras 24b, 24d, 24f) ocorreram diferentes ajustes para cada escala. Na escala de $15 \mathrm{~min}$, ajustou-se um polinômio de segundo grau, enquanto para a escala horária e diurna houve um ajuste linear simples. Na escala de $15 \mathrm{~min}$, até o valor de $0,4 \mathrm{MJ} . \mathrm{m}^{-2}$, os valores se diferenciaram até no máximo $5 \%$, tornando-se mais diferenciados na faixa entre 0,4 e 0,5 MJ.m ${ }^{-2}$, na qual a diferença percentual média chegou, no limite, a 19,5\%. Para a escala horária (Figura 24d) foi observada uma superestimativa média de 4,6\% sobre os valores medidos. Na escala diurna (Figura 24f), o Rn estimado pelo modelo apresentou diferenças médias entre 13,5\% para o limite inferior de valores observados e $4 \%$ para o limite superior. Deve-se ressaltar o pequeno número de dados diários.

Para a primavera, o ajuste das curvas para as três escalas estudadas foi linear, passando pela origem dos eixos. Apesar dos altos valores de $\mathrm{R}^{2}$, a estimativa pelo modelo levou a diferenças muito grandes, com superestimativas da ordem de 37 a $39 \%$, diferentemente do que se observou para as estações de outono e inverno. A tendência de ajuste dos dados se assemelha a estação de outono, mas na primavera, os valores estimados pelo modelo foram inferiores, devido às diferenciadas condições de radiação e do renque.

No verão pode-se observar um comportamento diferenciado no estudo das relações em escalas de tempo diferenciadas. $\mathrm{O}$ ajuste dos dados seguiu a tendência observada para a estação de inverno, mas a dispersão de dados nesse caso foi superior. Na Figura 25b, observa-se uma elevada dispersão de dados para a escala de $15 \mathrm{~min}$, confirmada pelo baixo valor de $\mathrm{R}^{2}=0,57$, sendo o melhor ajuste obtido com uma polinomial de segundo grau. Quando integrados na escala horária (Figura 25d), o ajuste permanece na forma polinomial de segundo grau, mas ocorre uma melhora significativa no coeficiente de determinação $\left(\mathrm{R}^{2}\right)$, alcançando um valor de 0,66 , pois além do incremento no valor do coeficiente, ocorre uma diminuição no número de dados, o que proporcionaria maior erro referente a cada ponto. Na escala diurna (Figura 25f), o ajuste foi linear simples com intercepto de 3,1 MJ.m ${ }^{-2}$.dia ${ }^{-1}$, apresentando uma superestimativa da ordem de $70 \%$ no limite inferior dos valores observados e de $21 \%$ no limite superior. Em resumo, para as duas estações contempladas na Figura 25, pode-se concluir que o modelo não conseguiu reproduzir adequadamente os valores observados, nas três escalas temporais. 

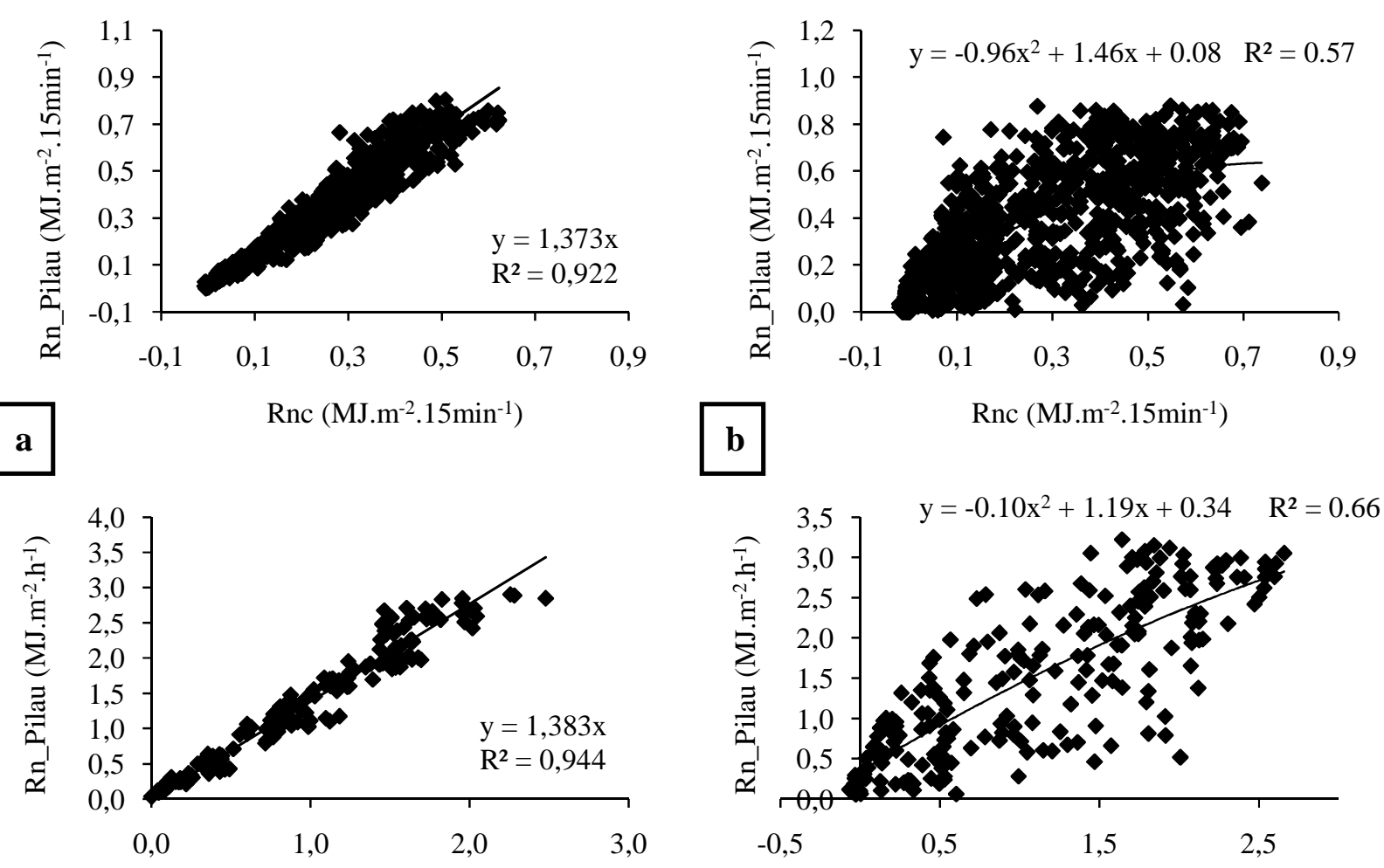

c $\quad \operatorname{Rnc}\left(\mathrm{MJ} \cdot \mathrm{m}^{-2} \cdot \mathrm{h}^{-1}\right)$
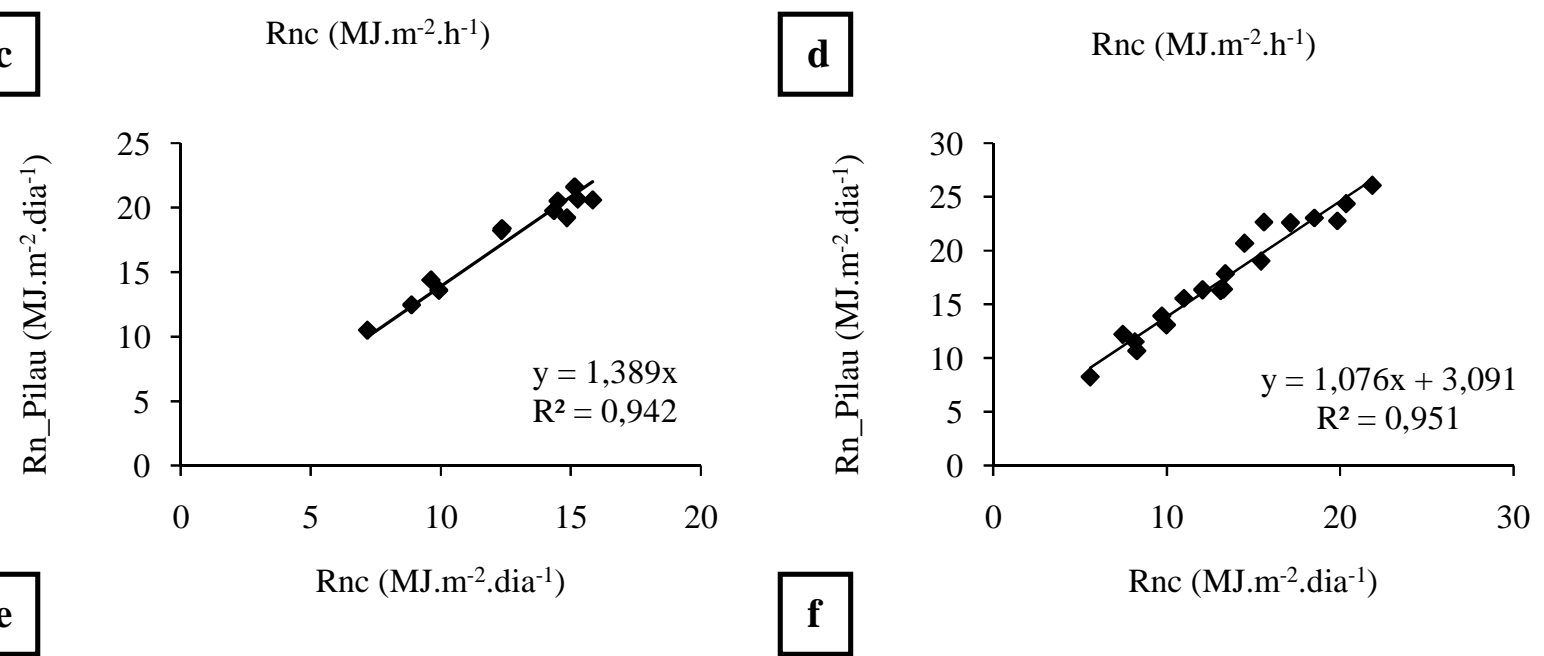

Rnc $\left(\mathrm{MJ} . \mathrm{m}^{-2} \cdot \mathrm{dia}^{-1}\right)$

Figura 25 - Relações do saldo de radiação medido (Rnc) com o estimado para o cafezal pelo modelo proposto (PILAU, 2005) nas escalas de 15min, horária e diurna para a primavera de 2008 (a,c,e) e o verão 2009 (b,d,f), Piracicaba 


\subsubsection{Limeira ácida}

O mesmo modelo foi empregado para a cultura da limeira, testando assim a sua aplicabilidade para outras culturas, com diferenças na silhueta, porte e orientação de renques.

As medidas foram realizadas em três estações do ano (verão, outono e inverno), sendo o modelo aplicado para o mesmo período, gerando dados em três escalas de tempo (15min, horária e diurna), nos quais as relações obtidas podem ser observadas nas Figuras 26 (verão e outono) e 27 (inverno).

Para o verão (Figuras 26a, 26c, 26e) foi observado nas três escalas de tempo ajuste linear simples. A dispersão dos dados foi elevada, resultando em valores baixos de coeficiente de determinação, sendo o melhor ajuste encontrado nos dados diurnos, com $R^{2}=0,64$ (Figura 26e). Coeficientes de determinação baixos podem estar ligados ao pequeno número de dados e ao fato de que a orientação do pomar permite que o Sol, que nesta época do ano tem valores de declinação solar semelhantes a latitude do local, tenha seu curso diário praticamente sobre a linha de plantio das limeiras ácidas, modificando valores de medidas dos sensores inferiores por sombreamento da estrutura do sistema.

Para o outono, foram obtidas relações lineares entre valores estimados e observados, mas com dispersão elevada de dados, principalmente na escala diurna, onde o coeficiente de determinação foi menor que 0,5 (Figura 26f). Para as escalas de $15 \mathrm{~min}$ e horária foram obtidas relações com menor dispersão, sendo na Figura $26 \mathrm{~d}$ observado um valor de $R^{2}=0,82$ e ajuste linear passando pela origem dos eixos. O modelo superestimou muito os valores em relação aos observados, com uma relação de 2:1 em todas as escalas.

Para o inverno, as relações apresentaram elevados coeficientes de determinação (acima de 0,9) e baixo grau de dispersão. Nas escalas de 15min e horária (Figuras 27a e 27b) observa-se que o modelo levou a valores em torno de $19 \%$ maiores que os valores observados, com baixo grau de dispersão. Na escala diurna (Figura 27c), o ajuste permaneceu linear, mas sem passar pela origem dos eixos, de maneira que as diferenças entre valores estimados e medidos foram altas, representando superestimativas de cerca de $100 \%$ no limite inferior e $10 \%$ no limite superior da faixa de valores. 

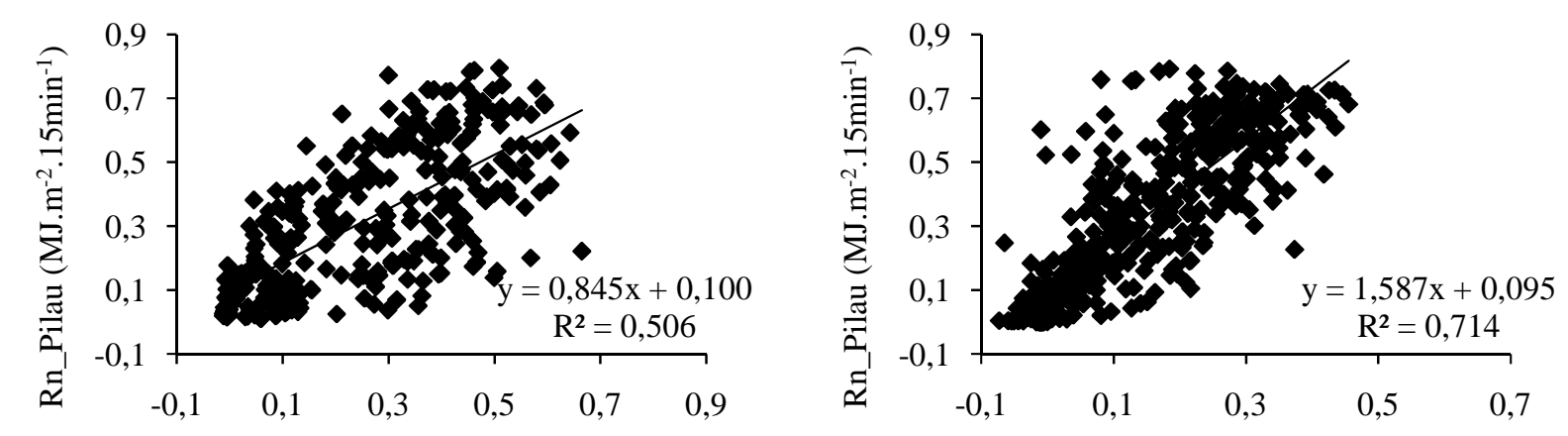

$\mathbf{a}$

Rnl (MJ.m $\left.{ }^{-2} .15 \mathrm{~min}^{-1}\right)$

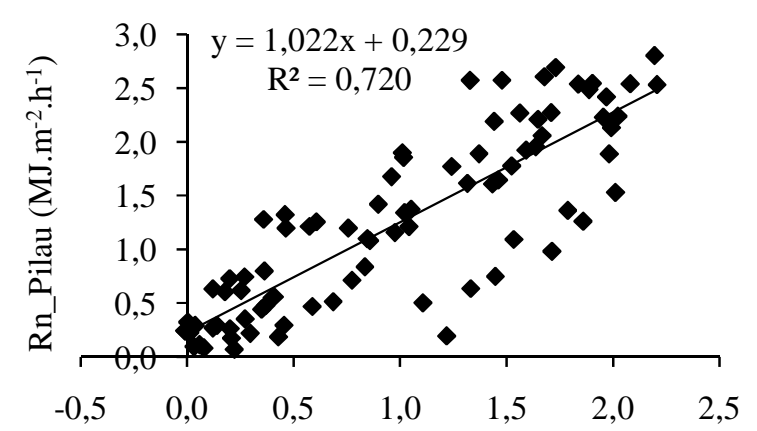

c

Rnl $\left(\mathrm{MJ} \cdot \mathrm{m}^{-2} \cdot \mathrm{h}^{-1}\right)$
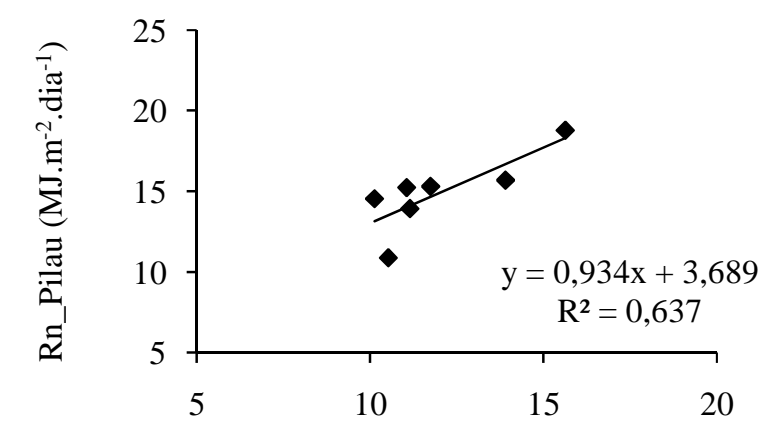

d

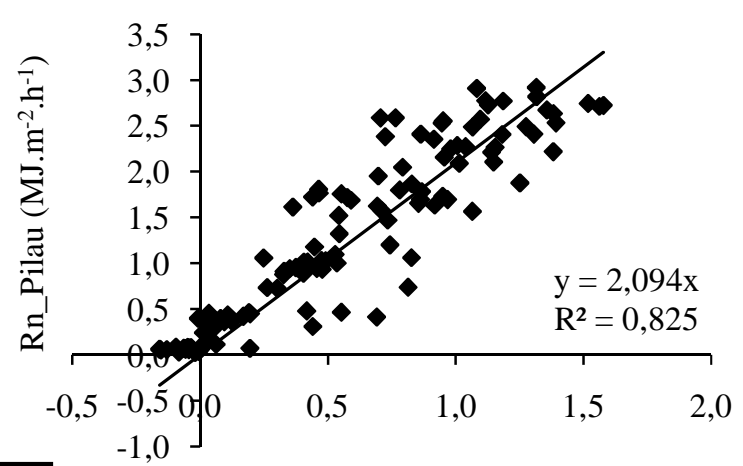

d $\quad \mathrm{Rnl}\left(\mathrm{MJ} \cdot \mathrm{m}^{-2} \cdot \mathrm{h}^{-1}\right)$

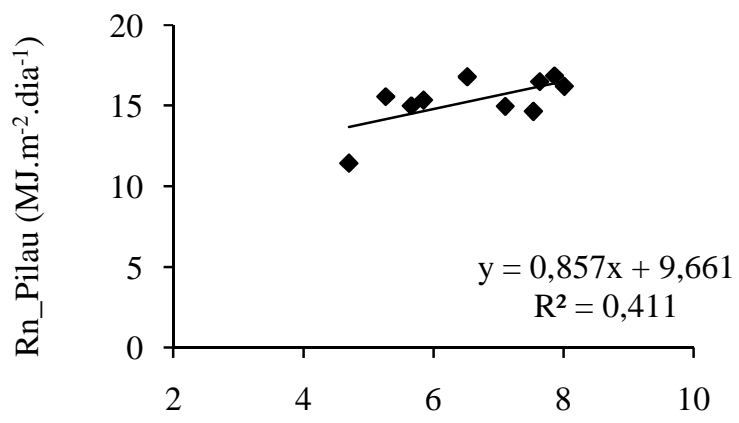

Rnl (MJ.m-2.dia-1)

Rnl $\left(M J \cdot m^{-2} \cdot \operatorname{dia}^{-1}\right)$

Figura 26 - Relações do saldo de radiação medido (Rnl) com o estimado para pomar de limeira ácida pelo modelo proposto (PILAU, 2005) nas escalas de 15min, horária e diurna para o verão de 2008 (a,c,e) e o outono de 2009 (b,d,f), Piracicaba 

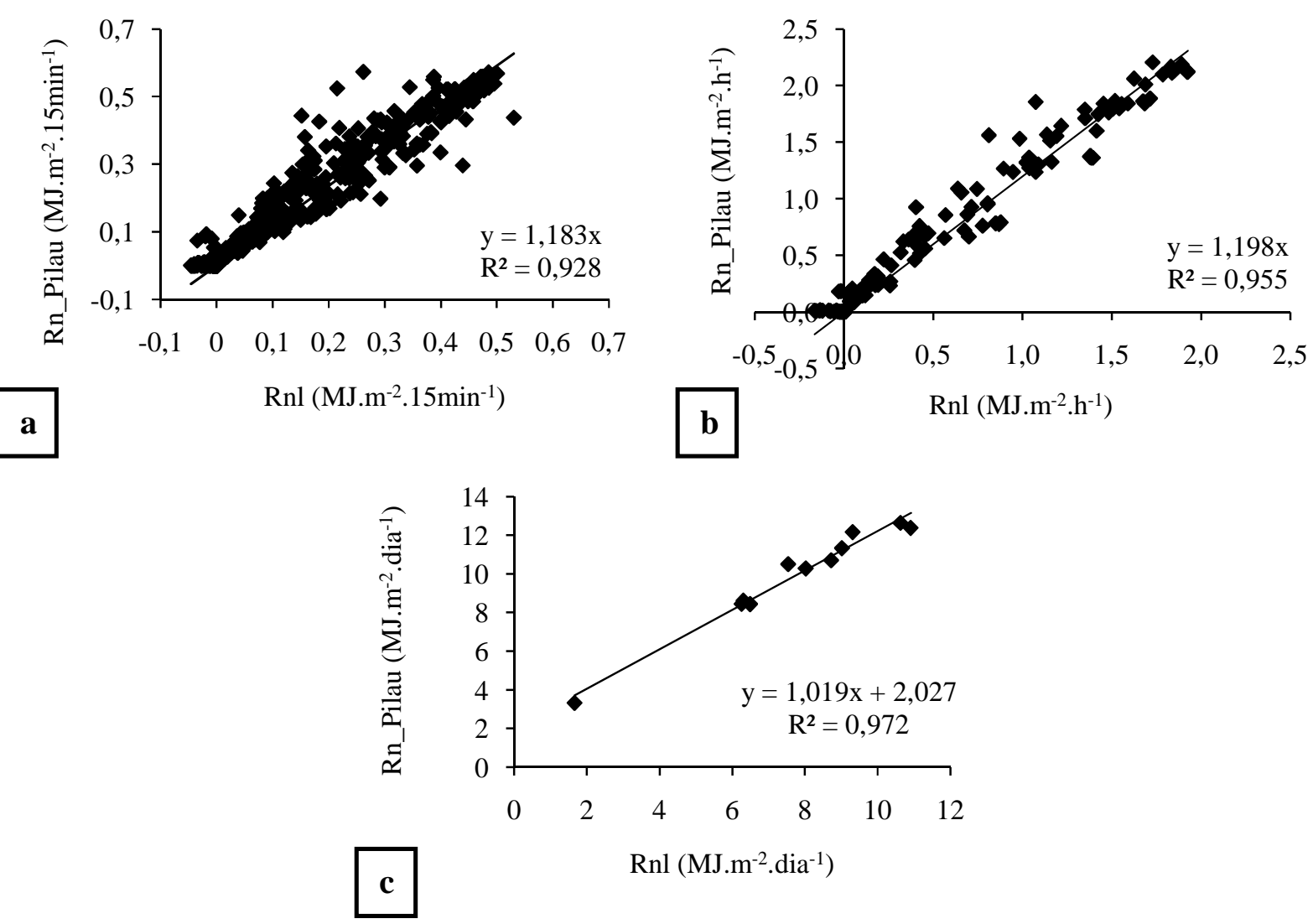

Figura 27 - Relações do saldo de radiação medido (Rnl) com o estimado para pomar de limeira ácida pelo modelo proposto (PILAU, 2005) nas escalas de 15min, horária e diurna para o inverno (a,b,c), Piracicaba, 2009

Segundo Pilau (2005), o modelo mesmo sendo mais simplificado em relação a alguns já existentes (CHARLES-EDWARDS E THORPE, 1976; MELO-ABREU, SNYDER E RIBEIRO, 2002 e RIOU, VALANCOGNE E PIERI, 1989) apresentou níveis similares de funcionalidade e precisão nas estimativas quando testado com variações na densidade de folhagem, mas salientou a necessidade de novos testes quanto a diferentes orientações de renque, espaçamentos e dimensões de renque, além do mesmo ter sido somente aplicado nas condições de outono.

Em seu trabalho, Pilau (2005) cita que o modelo se torna funcional na escala diurna, tendo elevado nível de ajuste mostrado por análises de regressão, com superestimativa em torno de 5\% sobre os valores observados. O presente estudo mostrou que para a mesma época e cultura em que o modelo foi anteriormente aplicado, houve uma boa estimativa para o saldo de radiação de copas, mas quando o mesmo foi aplicado ao longo do ano na mesma cultura, e em diferente espécie vegetal, o modelo não foi capaz de prover estimativas confiáveis. 


\subsection{Estimativa do saldo de radiação pelo modelo proposto por Oyarzun (2005)}

\subsubsection{Cafezal}

Este modelo de interceptação de radiação para pomares é baseado em relações geométricas que envolvem o movimento solar e a posição e orientação dos renques. Posteriormente ao seu desenvolvimento (OYARZUN, 2005; OYARZUN, STÖCKLE e WHITING, 2007) aplicaram-no para um conjunto de culturas que apresentavam geometrias distintas como videira, cerejeira, pereira e macieira nas quais a cobertura do solo nas entrelinhas era gramada, exceto para videira, onde o solo era desnudo. O modelo mostrou-se eficiente em estimar a interceptação de radiação solar na escala horária e diurna em todas as situações onde foi aplicado nesses trabalhos.

A comparação entre valores estimados e observados é visualizada nas Figuras 28 (outono e inverno) e 29 (primavera e verão). Em todos os casos, as relações entre valores estimados pelo modelo e observados pelo sistema integrador indicaram um bom ajuste linear, com passagem da reta ajustada pela origem dos eixos.

Para o outono e o inverno, observa-se que os valores originários do modelo foram 6,5 a $10,6 \%$ superiores aos medidos, sem dispersão elevada. Para a primavera o modelo simulou valores também ligeiramente superiores ao observados, em torno de 7\% (Figuras 29a e 29b), sendo que para o verão a tendência foi inversa, com valores subestimados em 7\% na escala horária (Figura 29c) e 1\% na escala diurna (Figura 29d), mas com elevada dispersão de dados na escala horária.

Essa dispersão pode ser decorrência da diferenciação da disponibilidade energética nos horários correspondentes eqüidistantes ao meio-dia solar, já que os sensores percorriam um caminho próximo da direção $\mathrm{N}-\mathrm{S}$, percebendo-se certa histerese temporal nas relações. 

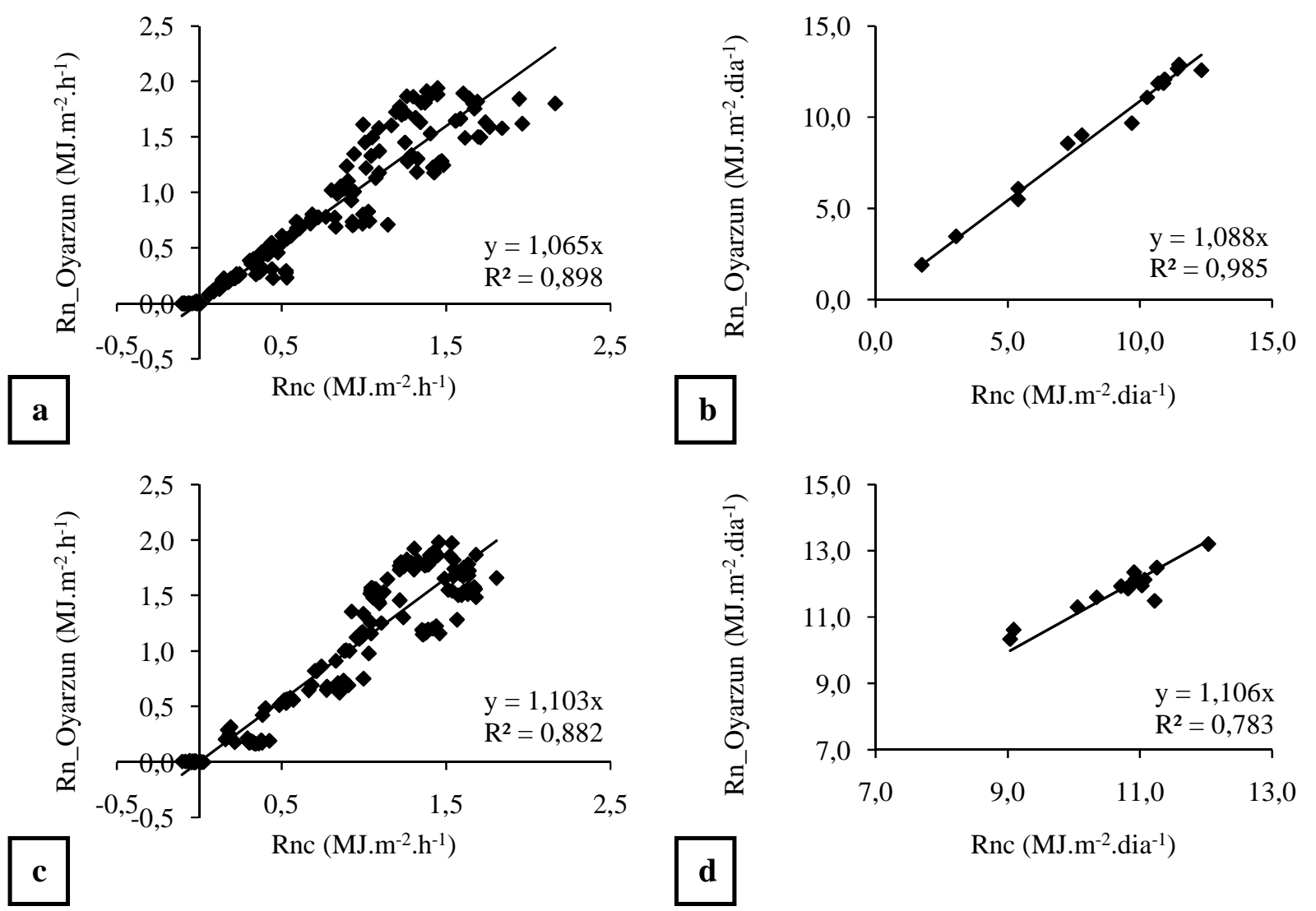

Figura 28 - Relações do saldo de radiação medido (Rnc) com o estimado para o cafezal pelo modelo proposto por Oyarzun (2005) nas escalas horária e diurna para o outono (a,b) e o inverno (c,d), Piracicaba, 2008

A grande dispersão de dados nas relações horárias (Figura 29c), também ocorreu para o modelo proposto por Pilau (2005), demonstrando que esta estação apresenta particularidades quanto ao regime radiativo, principalmente por apresentar elevados valores de irradiância solar, mas ao mesmo tempo, ser a estação com maior ocorrência de chuvas, e conseqüentemente, períodos do dia com alta nebulosidade. Essa peculiaridade dificulta a utilização de modelos que não levam em conta as variações das condições ambientais ao longo do dia. Quando integrados na escala diurna, houve uma significativa melhora na correlação, com baixa dispersão nos dados, valor de $\mathrm{R}^{2}=0,94$ e uma relação de $1: 1$ entre valores medidos e estimados pelo modelo. Isso mostra que, embora o modelo não acompanhe as variações horárias, na escala diurna ele apresenta ótimo desempenho. 

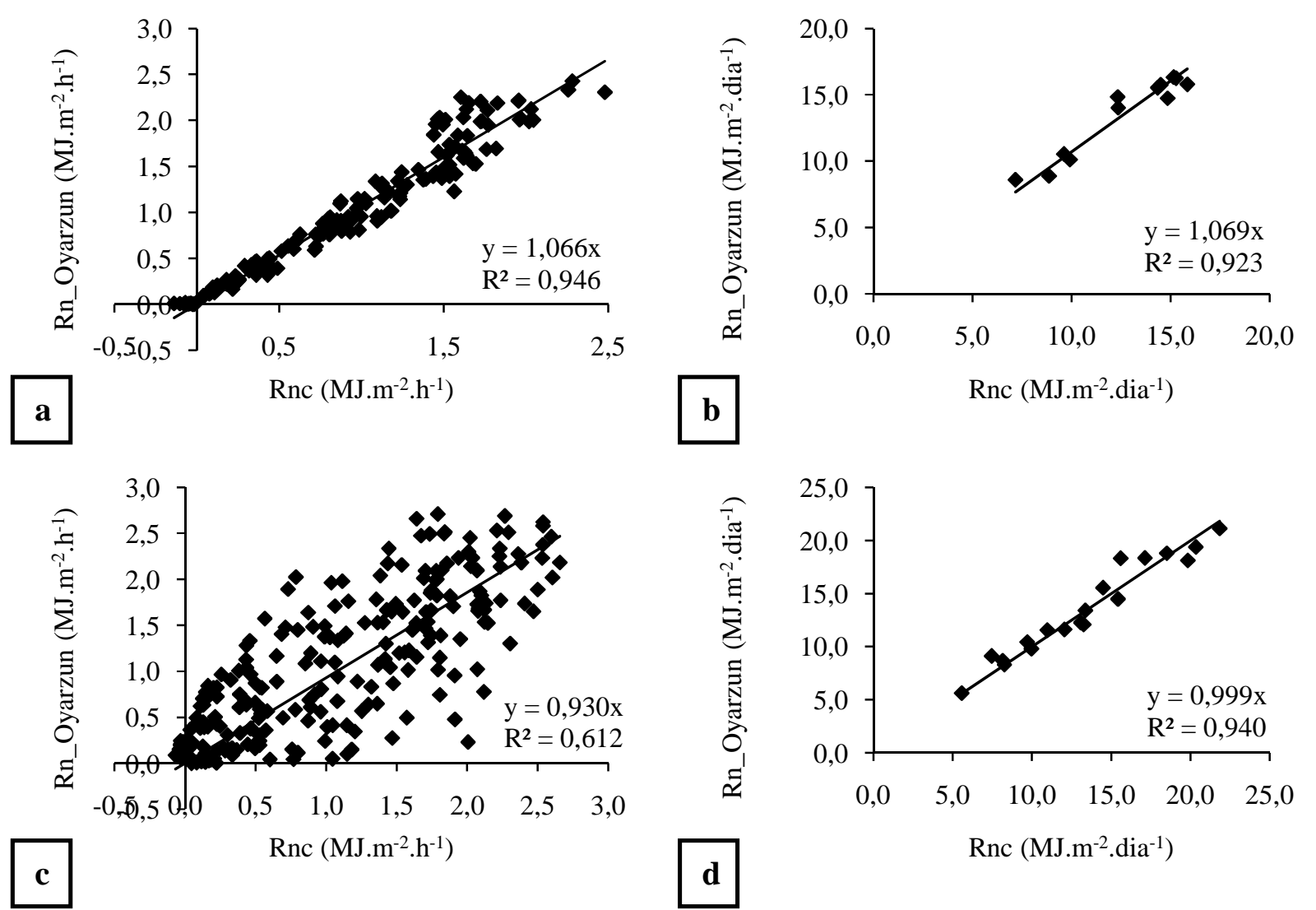

$\mathbf{b}$

Rnc $\left(M J \cdot m^{-2} \cdot \operatorname{dia}^{-1}\right)$

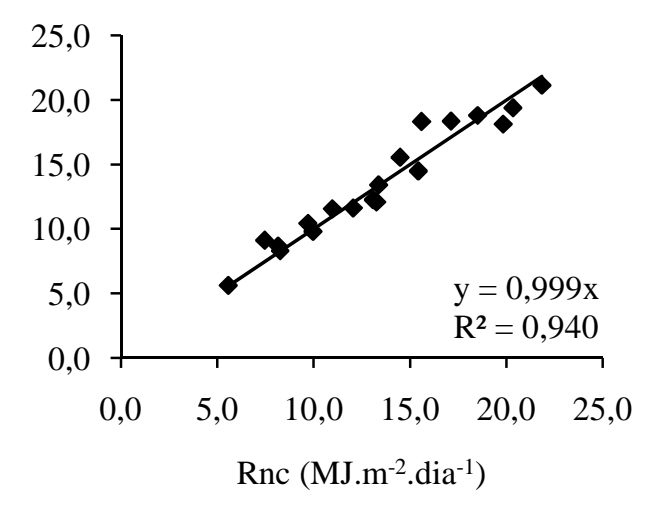

Figura 29 - Relações do saldo de radiação medido (Rnc) com o estimado para o cafezal pelo modelo proposto por Oyarzun (2005) nas escalas horária e diurna para a primavera de 2008 (a,b) e o verão de 2009 (c,d), Piracicaba

\subsubsection{Limeira ácida}

Os resultados das relações obtidas entre valores estimados pelo modelo de Oyarzun e os medidos pelo sistema integrador para o renque no pomar de limeira ácida estão apresentados na Figura 30.

Houve grande dispersão dos dados horários no verão, entre valores estimados e observados. Na escala diurna ocorreu uma superestimativa em torno de $22 \%$ dos dados em relação aos observados, ressaltando-se o pequeno número de dados diários, que contribuíram para manter-se uma dispersão elevada. Um ajuste polinomial de segundo grau representou melhor a relação para o caso dos valores horários e diários de outono, onde o modelo tendeu a produzir valores diários estimados muito superiores ao medidos. No inverno observa-se os melhores 
ajustes, com baixa dispersão de dados, $\mathrm{R}^{2}$ elevados, e superestimativas de 8 e $18 \%$ para as escalas horária e diurna, respectivamente.

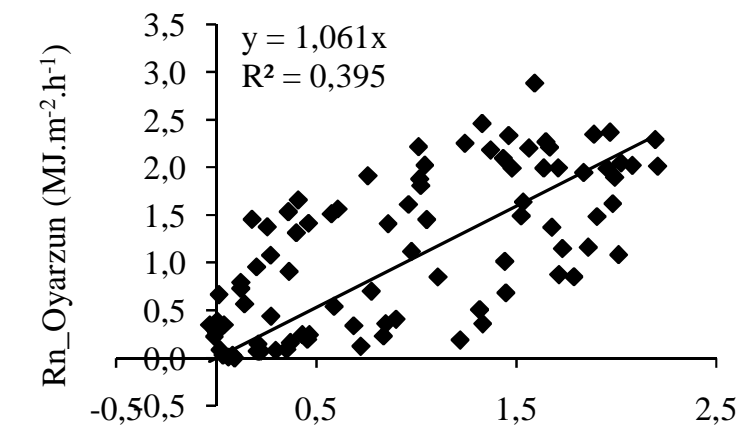

$\mathbf{a}$

Rnl $\left(\mathrm{MJ} . \mathrm{m}^{-2} \cdot \mathrm{h}^{-1}\right)$

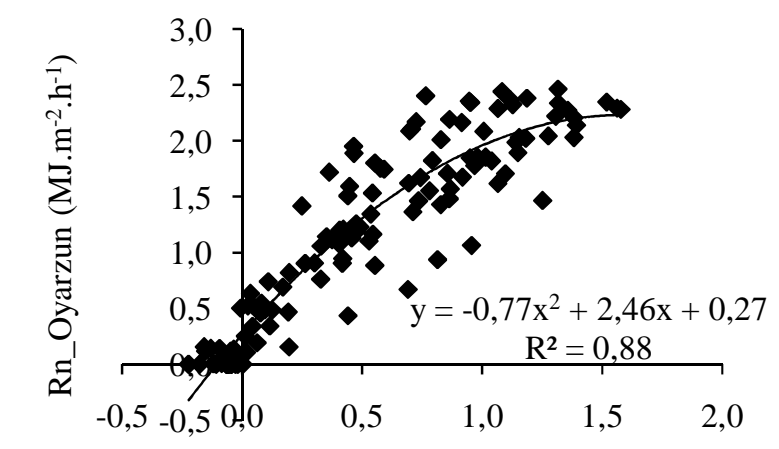

$\operatorname{Rnl}\left(\mathrm{MJ} . \mathrm{m}^{-2} \cdot \mathrm{h}^{-1}\right)$

c

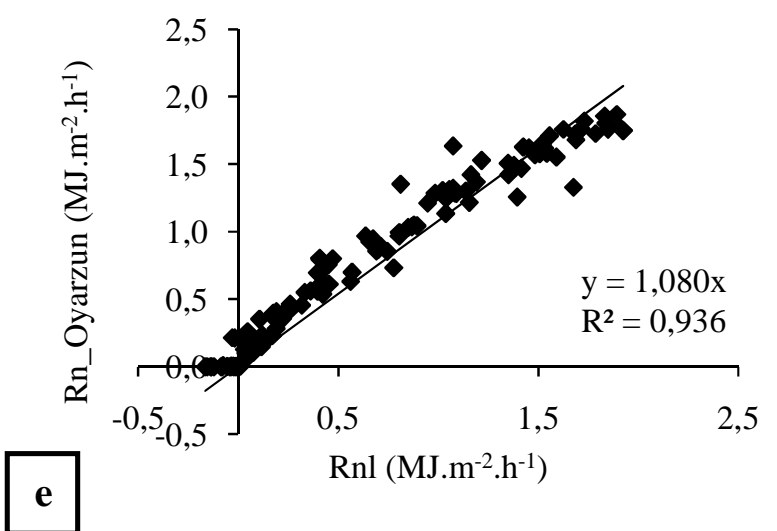

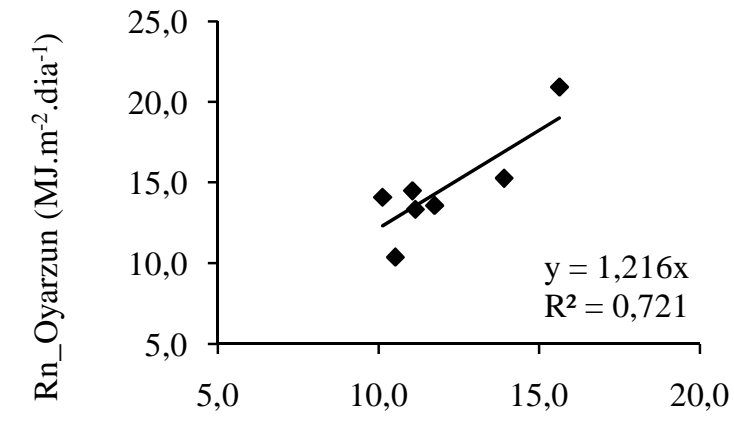

$\mathbf{b}$

Rnl (MJ.m $\left.{ }^{-2} \cdot \operatorname{dia}^{-1}\right)$

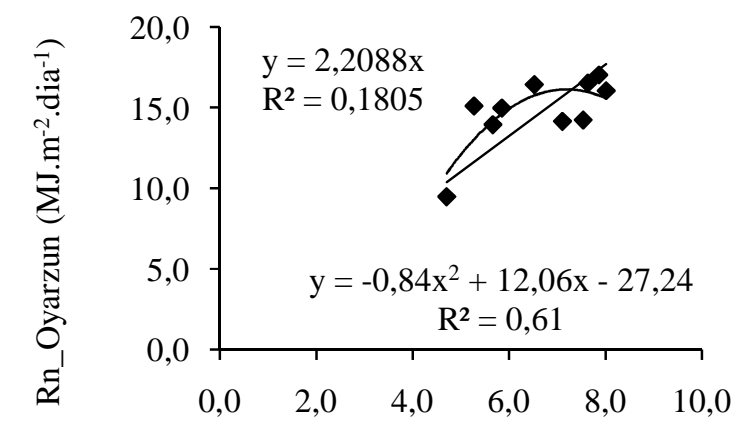

d

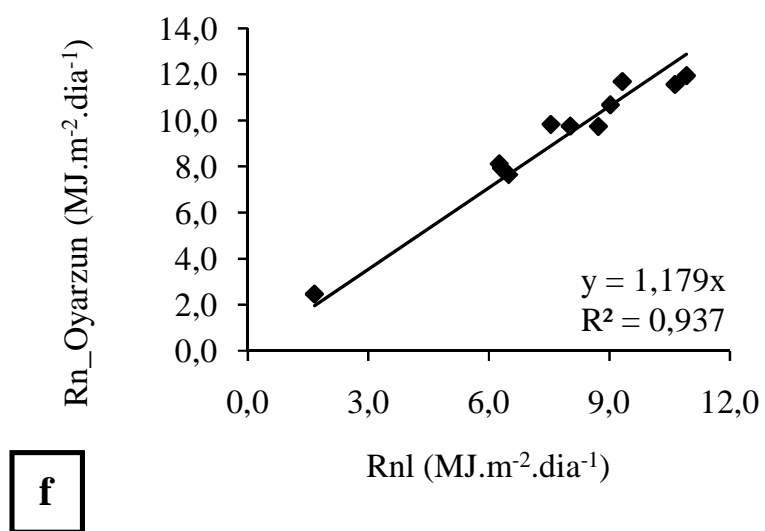

Figura 30 - Relações do saldo de radiação medido (Rnl) com o estimado para o pomar de limeira ácida pelo modelo proposto por Oyarzun (2005) nas escalas horária e diurna para o verão de 2008 (a,b), o outono (c,d), e o inverno de 2009 (e,f), Piracicaba 


\subsection{Comparação entre modelos de estimativa do saldo de radiação de copas}

Até este ponto discutiu-se o desempenho dos modelos em cada cultura pela análise das relações encontradas entre os valores estimados e observados. Neste item é feita uma avaliação mais abrangente, pelo uso de índices estatísticos para comparação de seus desempenhos nas diferentes estações do ano e culturas. No final, faz-se uma avaliação comparativa e global entre os modelos.

São realizadas comparações nas escalas horárias e diurnas, visto que no modelo de Oyarzun é a escala mínima de trabalho. Além disso, há um interesse prático maior de se trabalhar nessas escalas do que na de $15 \mathrm{~min}$.

A análise é feita com base nos indicadores $b$ (coeficiente angular da reta), $R^{2}$ (coeficiente de determinação da equação ajustada), D (índice de concordância de Willmott) e MAE (erro absoluto médio em \%), sendo indicado o índice CRM apenas para visualizar se o modelo apresenta tendência de subestimar ou superestimar os dados observados (CRM negativo ou positivo, respectivamente). Para a escala diurna, tendo-se em conta que as melhores relações entre valores estimados e observados foram sempre lineares, apresenta-se também os coeficientes linear (a) e angular (b) das retas de regressão, além de $\mathrm{R}^{2}$.

Foram adotados os critérios de De Jager (1994), considerando o modelo confiável quando $0,9<\mathrm{b}<1,1 ; \mathrm{R}^{2}>0,80 ; \mathrm{D}>0,80$ e MAE $<20 \%$. Nas tabelas 2 e 3 são encontrados os resultados dessa análise estatística. Observa-se que para o outono de 2009, no pomar de limeira ácida, o desempenho dos três modelos mostrou-se insatisfatório. Como nessa estação verificou-se a ocorrência de problemas na manutenção dos saldo-radiômetros superiores, que deve ser um fator que contribuiu bastante para a variabilidade observada, optou-se por descartar esses dados na análise comparativa. Deve-se ressaltar, também, que no verão de 2009 foram feitas observações com o sistema integrador por somente 7 dias no pomar, que o número de dias de observação foi menor do que no cafezal, o que pode em princípio afetar determinadas comparações.

A análise estatística indica que para o cafezal o modelo de Beer mostrou-se satisfatório na escala diurna (tabela 2), mas não satisfatório pelo índice MAE (\%) no inverno e verão para escala horária, embora com valores de D elevados.

O modelo de Pilau não se mostrou satisfatório para o cafezal no inverno pelos indicadores $\mathrm{R}^{2}$ e $\mathrm{D}$, na primavera pelo D e pelo $\operatorname{MAE}(\%)$ e no verão pelo MAE (\%), na escala diurna. Na 
escala horária, o modelo não foi satisfatório no verão pelos três indicadores e no inverno pelo $\operatorname{MAE}(\%)$.

Com exceção do inverno, o modelo de Oyarzun foi indicado como confiável nas outras três estações na escala diurna para o cafezal, enquanto que para a escala horária não se mostrou confiável pelo MAE (\%) para verão e inverno.

Deve-se considerar que a definição do limite de confiabilidade dos modelos baseou-se nos critérios de De Jager (1994), tendo sido utilizado também por Annandale et al. (2004) para testar a precisão da estimativa de um modelo de transmissão de radiação por copas de frutíferas, por eles proposto.

Para o cafezal, houve melhor desempenho global do modelo da lei de Beer, seguido em ordem decrescente pelo de Oyarzun e o de Pilau. Os resultados obtidos com a lei de Beer estão de acordo com o observado por Marin (2003) e por Pilau (2005) ao trabalharem, respectivamente, em cafezal adulto e em cafezal em formação. Esses autores somente fizeram avaliações do desempenho do modelo baseadas em valores de $\mathrm{R}^{2}$ e de coeficiente angular (b). Marin (2003) trabalhou em dois meses de primavera (setembro e outubro) na escala de 15min, chegando a subestimativa média de $8 \%\left(\mathrm{R}^{2}=0,936\right)$. Pilau (2005) trabalhou no outono (março a maio) onde, variando-se a área foliar das árvores sob estudo, encontrou valores de b $(0,83$ a 1,06$)$ e de $R^{2}$ elevados e variáveis com a área foliar, demonstrando a confiabilidade do modelo nas escalas de 15 min e diurna.

$\mathrm{Na}$ validação do modelo de Pilau pelo próprio autor (PILAU, 2005) no cafezal em formação, com uso somente dos indicadores $b$ e $\mathrm{R}^{2}$, foi verificado bom desempenho do modelo em ambas as escalas de tempo (15min e diurna), com superestimativa máxima de $7 \%$ e subestimativa máxima de $1 \%$, com $\mathrm{R}^{2}$ variando entre 0,744 e 0,923 na escala de $15 \mathrm{~min}$. Para a escala diurna, o valor de $\mathrm{b}$ foi 1,05 e $\mathrm{R}^{2}=0,907$, muito próximos dos obtidos no presente estudo para a mesma época.

Os resultados obtidos na aplicação do modelo de Oyarzun no cafezal estão de acordo com os observados por esse autor e colaboradores, em dois locais dos Estados Unidos e quatro espécies frutíferas (OYARZUN, STÖCKLE E WHITING, 2007), com valores de MAE (\%) inferiores a $10 \%$ na escala diurna e entre 6,7 e 16,8\% na escala horária. Entretanto, o limite de D maior que 0,8 para indicar confiabilidade, não foi atingido na escala diurna para três dos seis 
pomares usados, mas na escala horária esse limite foi superado em todos os pomares, indicando confiabilidade do modelo.

No pomar de limeiras, no qual se decidiu descartar da análise os dias de medidas do outono, os três métodos foram considerados não confiáveis pelos indicadores MAE (\%), $\mathrm{R}^{2}$ e D nas medidas diurnas do verão e confiáveis nas do inverno (com pequena restrição para o modelo de Pilau de acordo com MAE (\%)). Na escala horária, os três métodos mostraram-se não confiáveis devido ao indicador MAE (\%), mas com diferença de que no inverno, os valores desse indicador foram pouco superiores ao limite de $20 \%$, o que poderia ser assumido que, numa classificação mais detalhada, o desempenho fosse considerado como razoavelmente confiável, mesmo porque os valores de D nessa escala horária estão acima de 0,80 , sendo bastante elevados para o inverno, indicando que nessa estação eles apresentaram um desempenho melhor do que no verão para os valores horários.

A escolha dos três modelos testados foi justificada pelo fato de que suas variáveis de entrada exigem medidas simples. É evidente que a estrutura de cada modelo é diferente, sendo a lei de Beer mais simples e os outros dois mais complexos, sem uma grande diferença nessa estrutura pelo fato de ambos serem de origem geométrica.

No modelo da lei de Beer, a variável básica de entrada é o coeficiente k, para o qual são encontrados valores bastante variáveis ao longo do dia (exemplo, 0,10 a 0,99), embora na média entre as estações não tenha ocorrido variação acentuada $(0,84$ a 0,89 no cafezal e 0,77 a 0,89 no pomar). Os valores médios de k para o cafezal são diferentes do encontrado por Marin (2003) de 0,67, enquanto Pilau (2005) observou valores entre 0,68 a 0,80, mas dependente do IAF. Entretanto, como k é especifico para a estrutura, IAF e porosidade de cada cobertura vegetal, os valores encontrados por Pilau (2005) e neste trabalho mostram certa coerência, pois a porosidade da copa no estudo de seu autor foi maior do que na do presente.

Os modelos de Pilau e Oyarzun empregam variáveis de entrada supostamente representativas dos seus valores médios para o trecho de renque, como é o caso das dimensões, área foliar e porosidade. A variabilidade destas, que ocorre entre árvores do trecho de renque estudado e de suas adjacências é uma fonte de erro, como verificado por Oyarzun, Stöckle e Whiting (2007), que pode levar à diferenças de desempenho dos dois modelos nas diferentes coberturas vegetais e estações do ano. 
O número de dias de medida e a faixa de variação dos valores, em conjunto com sua distribuição nesta faixa afetam os valores dos indicadores de desempenho, o que pode justificar o pior desempenho dos três modelos no pomar para o verão, no qual foram feitas observações somente em sete dias do mês de dezembro de 2008.

Em termos globais, os modelos apresentaram no cafezal melhor desempenho frente aos valores medidos no pomar. Além dos fatores citados no parágrafo anterior que podem ter contribuído para isso, pois houve maior número de dias de observação no cafezal, juntamente com amplitude de variação dos valores e sua distribuição ao longo da faixa observada, deve-se considerar o aspecto de amostragem das medidas permitida pelos sistemas integradores. Conforme já discutido por McNaughton et al. (1992) é difícil definir o grau de exatidão das medidas pela técnica utilizada.

Conforme relatado no item 4.2, a discussão então realizada não permite uma definição sobre a exatidão e consistência dos dados de saldo de radiação observados, ainda mais porque para o pomar, aquela discussão foi baseada em apenas alguns dias de medidas de transpiração e evapotranspiração, servindo somente para se avaliar a ordem de grandeza dos valores diários. Deve-se considerar, além dos problemas citados na medida do verão no pomar, que o sistema neste utilizado tinha características de dimensões e de percurso diferentes daquelas do cafezal, que vinha sendo utilizado desde 2003. O aspecto de dimensão do arco e o número de sensores nele instalados merece uma avaliação mais criteriosa em trabalhos futuros com coberturas de grande porte, como em pomares. Por exemplo, o perímetro do arco do pomar era de cerca de $19 \mathrm{~m}$, com utilização de 12 sensores, enquanto no cafezal era de 7,3 m e 8 sensores, ou seja, um perímetro de amostragem aproximadamente 50\% maior no pomar. Isso significa que a amostragem da área lateral da copa, na geometria cilíndrica, por cada saldo-radiômetro, foi muito melhor no cafezal do que no pomar, o que pode ter contribuído para maior erro nesta última cobertura.

Outro problema ocorrido no pomar foi perda de uma árvore no final do trecho de renque amostrado e de uma na linha de plantio adjacente a partir de fevereiro de 2009, sendo impossível naquele instante reinstalar o sistema em outro trecho de renque. Apesar desses problemas, a técnica empregada no pomar mostrou-se de grande potencial de uso, merecendo sua reaplicação em estudos futuros, que levem em conta os problemas aqui relatados. 
Tabela 2 - Indicadores estatísticos de desempenho (confiabilidade) dos modelos de estimativa de saldo de radiação das copas de cafeeiros e de limeiras ácidas em comparação com os dados medidos na escala diurna

\begin{tabular}{|c|c|c|c|c|c|c|c|c|c|c|c|c|}
\hline \multirow{2}{*}{$\begin{array}{c}\text { Estações do } \\
\text { ano }\end{array}$} & \multicolumn{6}{|c|}{ Cafeeiro } & \multicolumn{6}{|c|}{ Limeira } \\
\hline & $\mathrm{n}^{*}$ & $\mathrm{a}$ & $\mathrm{b}$ & $R^{2}$ & $D$ & $M A E \%$ & $\mathrm{n}$ & $\mathrm{a}$ & $\mathrm{b}$ & $R^{2}$ & $D$ & $M A E \%$ \\
\hline & \multicolumn{12}{|c|}{ Lei de Beer } \\
\hline Out (2008) & 14 & - & 0,98 & 0,98 & 0,99 & 4,3 & - & - & - & - & - & - \\
\hline Inv (2008) & 15 & - & 1,00 & 0,81 & 0,96 & 1,8 & - & - & - & - & - & - \\
\hline Prim (2008) & 12 & - & 0,98 & 0,98 & 0,99 & 2,9 & - & - & - & - & - & - \\
\hline Ver $(2008 / 09)$ & 19 & - & 1,00 & 0,97 & 0,99 & 3,9 & 7 & - & 1,32 & 0,71 & 0,59 & 31,0 \\
\hline Out (2009) & - & - & - & - & - & - & 10 & 5,90 & 1,14 & 0,55 & 0,26 & 101,4 \\
\hline Inv (2009) & - & - & - & - & - & - & 11 & - & 0,87 & 0,91 & 0,93 & 12,3 \\
\hline
\end{tabular}

Modelo Pilau

\begin{tabular}{lrrrrrrrrrrrr}
\hline Out (2008) & 14 & - & 1,04 & 0,94 & 0,98 & 7,7 & - & - & - & - & - & - \\
Inv (2008) & 15 & 5,54 & 0,52 & 0,75 & 0,79 & 4,0 & - & - & - & - & - & - \\
Prim (2008) & 12 & - & 1,39 & 0,94 & 0,63 & 39,6 & - & - & - & - & - & - \\
Ver (2008/09) & 19 & 3,09 & 1,08 & 0,95 & 0,83 & 30,6 & 7 & 3,69 & 0,93 & 0,64 & 0,65 & 24,1 \\
Out (2009) & - & - & - & - & - & - & 10 & 9,70 & 0,86 & 0,41 & 0,20 & 131,8 \\
Inv (2009) & - & - & - & - & - & - & 11 & 2,03 & 1,02 & 0,97 & 0,84 & 28,2 \\
\hline
\end{tabular}

Modelo Oyarzun

\begin{tabular}{lrrrrrrrrrrrr}
\hline Out (2008) & 14 & - & 1,09 & 0,99 & 0,98 & 9,2 & - & - & - & - & - & - \\
Inv (2008) & 15 & - & 1,11 & 0,78 & 0,61 & 10,7 & - & - & - & - & - & - \\
Prim (2008) & 12 & - & 1,07 & 0,92 & 0,96 & 7,6 & - & - & - & - & - & - \\
Ver (2008/09) & 19 & - & 1.00 & 0,94 & 0,99 & 6,2 & 7 & - & 1,22 & 0,72 & 0,71 & 21,6 \\
Out (2009) & - & - & - & - & - & - & 10 & 6,55 & 1,25 & 0,61 & 0,21 & 123,7 \\
Inv (2009) & - & - & - & - & - & - & 11 & - & 1,18 & 0,94 & 0,91 & 19,4 \\
\hline
\end{tabular}

\footnotetext{
*n é o número de dados

a é o coeficiente linear da reta de regressão

b é o coeficiente angular da reta

$\mathrm{R}^{2}$ é o coeficiente de determinação

D é o índice de concordância de Willmott

MAE (\%) é o erro médio absoluto expresso em (\%).
} 
Tabela 3 - Indicadores estatísticos de desempenho (confiabilidade) dos modelos de estimativa de saldo de radiação das copas de cafeeiros e de limeiras ácidas em comparação com os dados medidos na escala horária

\begin{tabular}{|c|c|c|c|c|c|c|c|c|}
\hline \multirow{2}{*}{ Estações do Ano } & \multicolumn{4}{|c|}{ Cafeeiro } & \multicolumn{4}{|c|}{ Limeira } \\
\hline & $\mathrm{n}^{*}$ & $D$ & MAE\% & $C R M$ & $n$ & $D$ & $M A E \%$ & $C R M$ \\
\hline & \multicolumn{8}{|c|}{ Lei de Beer } \\
\hline Outono (2008) & 168 & 0,97 & 20,0 & 0,020 & - & - & - & - \\
\hline Inverno (2008) & 180 & 0,96 & 23,0 & $-0,001$ & - & - & - & - \\
\hline Primavera (2008) & 144 & 0,95 & 13,6 & 0,018 & - & - & - & - \\
\hline Verão $(2008 / 09)$ & 218 & 0,90 & 33,0 & $-0,002$ & 84 & 0,81 & 57,4 & $-0,310$ \\
\hline Outono (2009) & - & - & - & - & 120 & 0,75 & 106,6 & $-1,014$ \\
\hline \multirow[t]{2}{*}{ Inverno (2009) } & - & - & - & - & 132 & 0,96 & 23,4 & 0,114 \\
\hline & \multicolumn{8}{|c|}{ Modelo Pilau } \\
\hline Outono (2008) & 168 & 0,99 & 14,2 & $-0,061$ & - & - & - & - \\
\hline Inverno (2008) & 180 & 0,99 & 11,2 & $-0,037$ & - & - & - & - \\
\hline Primavera (2008) & 144 & 0,80 & 39,2 & $-0,396$ & - & - & - & - \\
\hline Verão (2008/09) & 218 & 0,80 & 57,8 & $-0,306$ & 84 & 0,89 & 41,8 & $-0,241$ \\
\hline Outono (2009) & - & - & - & - & 120 & 0,68 & 130 & $-1,318$ \\
\hline \multirow[t]{2}{*}{ Inverno (2009) } & - & - & - & - & 132 & 0,97 & 28,4 & $-0,282$ \\
\hline & \multicolumn{8}{|c|}{ Modelo Oyarzun } \\
\hline Outono (2008) & 168 & 0,97 & 20,7 & $-0,091$ & - & - & - & - \\
\hline Inverno (2008) & 180 & 0,96 & 21,8 & $-0,107$ & - & - & - & - \\
\hline Primavera (2008) & 144 & 0,98 & 12,7 & $-0,073$ & - & - & - & - \\
\hline Verão $(2008 / 09)$ & 218 & 0,89 & 37,5 & $-0,007$ & 84 & 0,81 & 55,2 & $-0,212$ \\
\hline Outono (2009) & - & - & - & - & 120 & 0,73 & 123,5 & $-1,237$ \\
\hline Inverno (2009) & - & - & - & - & 132 & 0,98 & 21,8 & $-0,194$ \\
\hline
\end{tabular}

*n é o número de dados

D é o índice de concordância de Willmott

MAE (\%) é o erro médio absoluto expresso em (\%)

CRM é o coeficiente residual de massa. 


\section{CONCLUSÕES}

Os sistemas móveis de integração espaço-temporal do saldo de radiação das copas de plantas de um trecho de renque de cafezal e de pomar de limeiras ácidas fornecem valores diários de magnitude coerente com valores de calor latente de vaporização de água das copas $(\lambda \mathrm{E})$. Entretanto é desejável que o desempenho de um sistema de grande porte, como o utilizado no pomar de limeiras ácidas, seja testado com maior número de sensores e por maior período do que o utilizado.

As curvas de variação do saldo de radiação ao longo do período diurno, medidas pelos saldo-radiômetros em cada posição em torno da copa mostram padrões diferenciados de acordo com a orientação do renque e com a época do ano.

Foram encontradas muito boas relações, dos tipos linear e quadrática, do saldo de radiação medido no renque do cafezal (Rnc) com a irradiância solar global ( $\mathrm{Rg}$ ) e o saldo de radiação de gramado (Rng), nas escalas de $15 \mathrm{~min}$, horária e diurna, com duas exceções de ajuste apenas razoável: no verão, nas escalas de $15 \mathrm{~min}$ e horária para Rg e Rng; e no inverno, na escala diurna para Rng.

Foram encontradas boas relações, do tipo linear, entre Rnl medido em renques de pomar de limeiras ácidas e Rg e Rng, nas três escalas temporais, com duas exceções de ajuste apenas razoável: no verão, nas escalas de 15min e horária e no outono na escala diurna para Rg e Rng.

De maneira geral, com as exceções acima citadas, confirmou-se para as duas culturas, a possibilidade de estimar o saldo de radiação médio de um trecho de renque nas três escalas temporais a partir da irradiância solar global e do saldo de radiação de gramado, com equações específicas para cada estação do ano e características geométricas, de porosidade e área foliar de cada cultura.

Na comparação com os dados medidos de saldo de radiação das copas, o modelo da lei de Beer apresentou altos índices de confiabilidade para as diferentes épocas do ano nas escalas 
horária e diurna para o cafezal; nos dois períodos do ano de estudo no pomar se mostrou confiável para o inverno, mas não no verão (dezembro) na escala diurna; na escala horária apresentou índices que indicam menor confiabilidade nas duas estações do ano no pomar.

Na comparação entre valores medidos e estimados de Rnc, o modelo de Pilau apresentou índices estatísticos de boa confiabilidade para o cafezal no outono e de menor confiabilidade nas outras três estações, enquanto na escala horária verificou-se boa confiabilidade no outono e inverno. Para o pomar, os índices estatísticos indicaram menor confiabilidade para o inverno nas duas escalas de temporais e muito pouca confiabilidade para o verão, principalmente na escala diurna.

Para o cafezal, o modelo de Oyarzun mostrou-se bem confiável na escala diurna, enquanto na escala horária somente no verão ele se mostrou menos confiável. Para o pomar, ele se mostrou confiável em ambas as escalas para o inverno e pouco confiável no verão. Ressalta-se que para o pomar, nesta última estação do ano, o número de dias de observação foi pequeno e concentrado no mês de dezembro, o que deve ter afetado, também, a análise estatística para os outros dois modelos no pomar. 


\section{REFERÊNCIAS}

ALÈGRE, C. Climats et caféiers d'Arabie. Agronomie Tropicale, Paris, v. 14, p. 23-58, 1959.

ALLEN, L.H. Model of light penetration into a wide row crop. Agronomy Journal, Madison, v. 66, p. 41-47, 1974.

ANGELOCCI, L.R. Radiation balance of coffee hedgerows. Revista Brasileira de Engenharia Agrícola e Ambiental, Campina Grande, v. 12, n. 3, p. 274-281, 2008.

ANGELOCCI, L.R.; VILLA NOVA, N.A. Medida de saldo de energia radiante na copa de lima ácida "Tahiti” e sua relação com a medida sobre gramado. In: CONGRESSO BRASILEIRO DE AGROMETEOROLOGIA, 11; REUNIÃO LATINO-AMERICANA DE AGROMETEOROLOGIA, 2, 1999. Florianópolis. Anais... Florianópolis: SBA, EPAGRI, p. 2192-2198, 1 CD-ROM.

ANGELOCCI, L.R.; VILLA NOVA, N.A.; COELHO FILHO, M.A. Relações entre o saldo de radiação na copa da árvore e a irradiância solar global em pomar de lima ácida "Tahiti". In: CONGRESSO BRASILEIRO DE AGROMETEOROLOGIA, 12; REUNIÃO LATINOAMERICANA DE AGROMETEOROLOGIA, 3, 2001. Fortaleza. Anais... Fortaleza: SBA, p. 817-818.

ANGELOCCI, L.R.; VILLA NOVA, N.A.; COELHO FILHO, M.A.; MARIN, F.R. Measurements of net radiation absorbed by isolated acid lime trees (Citrus latifolia Tanaka). Journal of Horticultural Science \& Biotechnology, Coventry, v. 79, n. 5, p. 699-703, 2004.

ANNANDALE, J.G.; JOVANOVIC, N.Z.; CAMPBELL, G.S.; DU SANTOY, N.; LOBIT, P. Two-dimensional solar radiation interception model for hedgerow fruit trees. Agricultural and Forest Meteorology, Amsterdam, v. 121, p. 207-225, 2004.

ASSOCIAÇÃO BRASILEIRA DA ÍNDUSTRIA DE CAFÉ. Disponível em: <http://www.abic.com.br>. Acesso em: $14 \mathrm{dez} 2009$.

ASSUNÇÃO, H.F.; ESCOBEDO J.F.; CARNEIRO, M.A.C. Eficiência de uso da radiação e propriedades óticas da cultura do amendoim. Pesquisa Agropecuária Tropical, Goiânia, v. 38, n. 3, p. 215-222, 2008.

BARBERA, G.; FATTA DEL BOSCO, G.; LO CASCIO, B. Effects of water stress on lemon summer bloom: the "forzatura" technique in the Sicilian citrus industry. Acta Horticulturae, Davis, v. 171, p. 391-397, 1985. 
BATERLINK, H.H. Radiation interception by forest trees: A simulation study on effects of stand density and foliage clustering on absorption and transmission. Ecological Modelling, Amsterdam, v. 105, p. 213-225, 1998.

BONAN, B. Water and Florida citrus: use, regulation, irrigation systems and management. Gainesville: University of Florida, Institute of Food and Agricultural Sciences, 2002. p. 163-174.

BROUGHAM, R.W. Interception of light by the foliage of pure and mixes stands of pasture plants. Australian Journal of Agricultural Research, Coolingwood, v. 9, p. 39-52, 1958.

BUTLER, D.R. Estimation of the transpiration rate in an apple orchard from net radiation and vapour pressure deficit measurements. Agricultural and Forest Meteorology, Amsterdam, v. 16, p. 277-289, 1976.

CAMARGO, A.P. Florescimento e frutificação do café arábica nas diferentes regiões cafeeiras do Brasil. Pesquisa Agropecuária Brasileira, Brasília, v.20, n. 7, p. 831-839, 1985.

CAMARGO, A.P.; CAMARGO, M.B.P. Definição e esquematização das fases fenológicas do cafeeiro arábica nas condições tropicais do Brasil. Bragantia, Campinas, v. 60, n. 1, p. 65-68, 2001.

CAMPBELL, G.S.; NORMAN, J.M. An introduction to environmental biophysics. 2nd ed. New York: Springer-Verlag, 1998. 286 p.

CARDOSO, A.P.S. Café: cultura e tecnologia primária. Lisboa: Silvas, 1994. 169p.

CARR, M.K.V. The water relations and irrigation requirements of coffee. Experimental Agriculture, Cambridge, v. 37, n. 1, p. 1-36, 2001.

CHARLES-EDWARDS, D.A; THORNLEY, J.H.M. Light interception by an isolated plant. A simple model. Annals of Botany, London, v. 37, p. 919-928, 1973.

CHARLES-EDWARDS, D.A.; THORPE, M.R. Interception of diffuse and direct-beam radiation by a hedgerow apple orchard. Annals of Botany, London, v. 40, p. 603-613, 1976.

CITTADINI, E. Development of a simulation model for potential production of sweet cherry: its usefulness to analyze planting density, 2002. 102 p. (M.Sc. Thesis) - Wageningen University, Wageningen, 2002.

COELHO, E.F.; MAGALHAES, A.F.J.; COELHO FILHO, M.A. Irrigação e fertirrigação em citros. Cruz das Almas: EMBRAPA, CNPMF, 2004. 16 p. (EMBRAPA. CNPMF. Circular Técnica, 72). 
COHEN, S.; RAO, R.S.; COHEN, Y. Canopy transmittance inversion using a line quantum probe for a row crop. Agricultural and Forest Meteorology, Amsterdan, v. 86, p. 225-234, 1997.

COMPANHIA NACIONAL DE ABASTECIMENTO - CONAB. Disponível em: <http://www.conab.com.br>. Acesso: 30 maio 2009.

CONSOLI, S.; O'CONNELL, N.; SNYDER, R. Measurements of light interception by orange orchard canopies: the case study of Lindsay (California). Journal of Irrigation and Drainage Engineering, Amsterdan, v. 132, p. 9-20, 2006.

COSTE, R. Coffee: The plant and the product. London: Macmillan Press, 1992. 154p.

CRUSE, R.R.; WIEGAND, C.L.; SWANSON, W.A. A new method of sap flow rate determination in stress. Biologia Plantarum, Praha, v. 15, p. 171-178, 1982.

DAMATTA, F.M. Exploring drought tolerance in coffee: a physiological approach with some insights for plant breeding. Brazilian Journal of Plant Physiology, Campinas, v. 16, n. 1, p. 1-6, 2004.

DAMATTA, F.M.; RAMALHO, J.D.C. Impacts of drought and temperature stress on coffee physiology and production: a review. Brazilian Journal of Plant Physiology, Campinas, v.18, n.1, p.55-81, 2006.

DE JAGER, J.M. Accuracy of vegetation evaporation ratio formulae for estimating final wheat yield. Water A.S., Pretória, v. 20, n. 4, p. 307-314, 1994.

DÍAZ-AMBRONA, C.H.; TARQUIS, A.; MÍNGUEZ, M.I.. Faba bean canopy modelling with a parametric open L-system: a comparison with the Monsi and Saeki model. Field Crops Research, Amsterdam, v. 58, p. 1-13, 1998.

DOORENBOS, J.; KASSAN, A.H. Yield response to water. Rome: FAO, 1979. 179 p. (FAO. Irrigation and Drainage Paper, 33).

FAHL, J.I.; CARELLI, M.L.C. Influência do sombreamento nas características fisiológicas envolvidas no crescimento de espécies de coffea. In: SIMPÓSIO INTERNACIONAL SOBRE CAFÉ ADENSADO, 1994, Londrina. Anais... Londrina: IAPAR, 1994. p. 289-290.

FONTANA, D.C.; BERLATO, M.A.; BERGAMASCHI, H. Balanço de radiação da soja em região subtropical do Brasil. Pesquisa Agropecuária Brasileira, Brasília, v. 26, n. 3, p. 411-418, 1991.

GATES, D.M. Biophysical ecology. New York: Springer-Verlag, 1980. 295p. 
GREEN, S.R. Radiation balance, transpiration and photosynthesis of an isolated tree.

Agricultural and Forest Meteorology, Amsterdam, v. 64, p. 201-221, 1993.

GREEN, S.R.; McNAUGHTON, K.G.; GREER, D.H.; McLEOD, D.J. Measurement of the increased PAR and net all-wave radiation absorption by an apple tree caused by applying a reflective ground covering. Agricultural and Forest Meteorology, Amsterdam, v. 76, p. 163-183, 1995.

GREEN, S.R.; McNAUGHTON, K.G.; WÜNSCHE, J.N.; CLOTHIER, B. Modeling light interception and transpiration of apple canopies. Agronomy Journal, Madison, v. 95, p. 1380-1387, 2003.

GUTIÉRREZ, M.V.; MEINZER, F.C. Energy balance and latent heat flux partitioning in coffee hedgerows at different stages of canopy development. Agricultural and Forest Meteorology, Amsterdam, v. 68, p. 173-186, 1994.

HAARER A.E. Modern Coffee Production. London: Leonard Hill, 1958. 221p.

JACKSON, J.E.; PALMER, J.W. Interception of light by model hedgerow orchards in relation to latitude, time of year and hedgerow configuration and orientation. Journal of Applied Ecology, London, v. 9, p. 341-358, 1972.

JACKSON, J.E.; PALMER, J.W. A simple model of light transmission and interception by discontinuous canopies. Annals of Botany, London, v. 44, p. 381-383, 1979.

KUMAR, D.; TIESZEN, L.L. Photosynthesis in Coffea arabica. Effects of light and temperature. Experimental Agriculture, Cambridge, v. 16, n. 1, p. 13-19, 1980.

KUNZ, J.H.; BERGONCI, J.I.; BERGAMASCHI, H.; DALMAGO, G.A.; HECKLER, B.M.M.; COMIRAN, F. Uso da radiação solar pelo milho sob diferentes preparos do solo, espaçamento e disponibilidade hídrica. Pesquisa Agropecuária Brasileira, Brasília, v. 42, n. 11, p. 1511-1520, 2007.

LANDSBERG, J.J. Diurnal energy, water and $\mathrm{CO}_{2}$ exchanges in an apple (Malus pumila) orchard. Journal of Applied Ecology, London, v. 12, p. 645-683, 1975.

LAPPI, J.; STENBERG, P. Joint effect of angular distribution of radiation and spatial pattern of trees on radiation interception. Ecological Modelling, Amsterdam, v. 112, p. 45-51, 1998.

LEMEUR, R. A method for simulating the direct solar radiation regime in sunflower, Jerusalem artichoke, corn and soybean canopies using actual stand structure data. Agricultural and Forest Meteorology, Amsterdam, v. 12, p. 229-247, 1973. 
LIU, B.Y.H.; JORDAN, R.C. The interrelationship and characteristic distribution of direct, diffuse and total solar radiation. Solar Energy, Amsterdam, v. 4, p. 1-19, 1960.

LOAGUE, K.; GREEN, R.E. Statistical and graphical methods for evaluating solute transport models: overview and application. Journal of Contaminant Hydrology, Amsterdam, v. 7, p. 51-73, 1991.

MACHADO, C.E.; MEDINA, C.L.; GOMES, M.M.A. Variação sazonal da fotossíntese, condutância estomática e potencial da água na folha de laranjeira 'Valência'. Scientia Agricola, Piracicaba, v. 59, n. 1, p. 53-58, 2002.

MARIN, F.R. Evapotranspiração, transpiração e balanço de energia em pomar de lima ácida Tahiti. 2000. 74 p. Dissertação (Mestrado em Física do Ambiente Agrícola) - Escola Superior de Agricultura “Luiz de Queiroz”, Universidade de São Paulo, Piracicaba, 2000.

MARIN, F.R. Evapotranspiração e transpiração máxima em cafezal adensado. 2003. 118 p. Tese (Doutorado em Física do Ambiente Agrícola) - Escola Superior de Agricultura "Luiz de Queiroz”, Universidade de São Paulo, Piracicaba, 2003.

MARISCAL, M.J.; ORGAZ, F.; VILLALOBOS, F.J. Radiation-use efficiency and dry matter partitioning of a young olive (Olea euopaea) orchard. Tree Physiology, Oxford, v. 20, p. 65-72, 2000.

McCULLOUGH, E.C.; PORTER, W.P. Computing clear day solar radiation spectra for the terrestrial ecological environment. Ecology, Durham, v. 52, p. 1008-1015, 1971.

McNAUGHTON, K.G.; GREEN, S.R.; BLACK, T.A.; TYNAN, B.R.; EDWARDS, W.R.N. Direct measurement of net radiation and photosynthetically active radiation absorbed by a single plant. Agricultural and Forest Meteorology, Amsterdam, v. 62, p. 87-107, 1992.

MELO-ABREU, P.; SNYDER, R.L.; RIBEIRO, A.C. Modeling radiation transmission, interception and reflection in a hedgerow apple orchard in the northeastern Portugal. Acta Horticulturae, Davis, v. 584, p. 73-80, 2002.

MONSI, M.; SAEKI, T. Uber den lichtfacktor in den pflanzen-gesell-schaften und seine bedeutung fur die Stoffproduktion. Japanese Journal of Botany, Tokio, v. 14, p. 22-52, 1953.

MONTEITH, J.L. Evaporation and environment. Symposium of Society of Experimental Biology, Cambridge, v. 19, p. 205-234, 1965.

NORMAN, J.M.; WELLES, J.M. Radiative transfer in an array of canopies. Agronomy Journal, Madison, v. 75, p. 481-488, 1983. 
NUTMAN, F.J. Studies of the physiology of Coffee arabica L. III Transpiration rates of the whole trees in relation to natural environmental conditions. Annals of Botany, London, v. 5, n. 17, p. 59-81, 1941.

OLIVEIRA, A.P.de; MACHADO, A.J.; ESCOBEDO, J.F. A new shadow-ring device form measuring diffuse solar radiation at surface. Journal of Atmospheric and Oceanic Technology, Boston, v. 19, n. 5, p. 698-708, 2002.

ORTOLANI, A.A.; PEDRO JR., M.J.; ALFONSI, R.R. Agroclimatologia e o cultivo de citrus. In: ENCONTRO NACIONAL DE CITRICULTURA, 4, 1977. Aracaju. Anais ... Aracaju: Sociedade Brasileira de Fruticultura, 1977. p. 21-41.

OYARZUN, R.L. Measurements and modeling of plant hydraulic conductance and solar radiation transfer processes in fruit tree orchards, with special reference to sweet cherry, 2005, 188p. (Ph.D. Dissertation), Washington State University, Washington, 2005.

OYARZUN, R.A.; STOCKLE, C.O.; WHITING, M.D. A simple approach to modeling radiation interception by fruit tree orchards. Agricultural and Forest Meteorology, Amsterdam, v. 142, p. 12-24, 2007.

PALMER, J.W. Diurnal light interception and a computer model of light interception by hedgerow apple orchards. Journal of Applied Ecology, London, v. 14, p. 601-614, 1977.

PALMER, J.W. The effect of row orientation, tree height, time of year and latitude on light interception and distribution in model apple hedgerow canopies. Journal of Horticultural Science, Coventry, v. 64, n. 2, p. 137-145, 1989.

PALMER, J.W., JACKSON, J.E. Seasonal light interception and canopy development in hedgerow and bed system apple orchards. Journal of Applied Ecology, London, v. 14, p. 539-549, 1977.

PEREIRA, A.; GREEN, S.R.; VILLA NOVA, N. Penman Monteith reference evapotranspiration adapted to estimate irrigated tree transpiration. Agricultural Water Management, Amsterdam, v. 83, n. 1, p. 153-161, 2006.

PEREIRA, A.R.; ANGELOCCI, L.R.; VILLA NOVA, N.A.; SENTELHAS, P.C. Estimating single tree net radiation using grass net radiation and tree leaf area. Revista Brasileira de Agrometeorologia, Santa Maria, v. 9, n. 2, p. 187-192, 2001.

PILAU, F.G. Saldo de radiação da copa de laranjeira num pomar e de renques de cafeeiros: medidas e estimativas, 2005, 92p. Tese (Doutorado em Física do Ambiente Agrícola) - Escola Superior de Agricultura “Luiz de Queiroz”, Universidade de São Paulo, Piracicaba, 2005. 
PILAU, F.G.; ANGELOCCI, L.R.; SCARPARE FILHO, J.A. Radiation balance of an orange tree in orchard and its relation with global solar radiation and grass net radiation. Revista Brasileira de Agrometeorologia, Piracicaba, v. 15, p. 257-266, 2007.

PIRE, R.; BAUTISTA, D.; ROJAS, E. The influence of soil moisture on the vegetative and reproductive growth of orange trees under tropical conditions. Acta Horticulturae, Leuven, n. 335, p. 527-534, 1993.

PROCTOR, J.T.A.; KYLE, W.J.; DAVIES, J.A. The radiation balance of an apple tree. Canadian Journal of Botany, New York, v. 50, p. 1731-1740. 1972.

RIDAO, E.; OLIVEIRA, C.F.; CONDE, J.R.; MINGUEZ, M.I. Radiation interception and use, and spectral reflectance os contrasting canopies of autumn sown faba beans and semi-leafless peas. Agricultural and Forest Meteorology, Amsterdam, v. 79, p. 183-203, 1996.

RIOU, C.; VALANCOGNE, C.; PIERI, P. Um modèle simple d'interception du rayonnement solaire par la vigne - vérication expérimentale. Agronomie, Paris, v. 9, p. 441-450, 1989.

RÖHRIG, M.; STÜTZEL, H.; ALT, C. A three-dimensional approach to modeling light interception in heterogeneous canopies. Agronomy Journal, Madison, v. 91, p. 1024-1032, 1999.

SCHULTZ, H.R. Leaf absorptance of visible radiation in Vitis vinifera L.: estimates of age and shade effects with a simple field method. Scientia Horticulturae, Amsterdam, v. 66, p. 93-102, 1996.

SIMON, J.; ANGELOCCI, L.R.; SCARPARE, F.V.; IRIGOYEN, A.I. Sistema de medidas para saldo de radiação em renques de espécies arbóreas: uso em lima ácida. In: CONGRESSO BRASILEIRO DE AGROMETEOROLOGIA, 16, 2009. Belo Horizonte. Anais... Belo Horinzonte, 2009, 1 CD-ROM.

SPIGEL-ROY, P.; GOLDSCHMIDT, E.E. Biology of citrus. London: Cambridge University Press, 1996. 230 p.

SPITTERS, C.; TOUSSANINT, H.; GOUDRIAAN, J. Separating the diffuse and direct component of global radiation and its implications for modeling canopy photosynthesis. Pt I. Component of incoming radiation. Agricultural and Forest Meteorology, Amsterdam, v. 38, p. 217-229, 1986.

STANHILL, G.; HOFSTEDE, G.J.; KALMA, J.D. Radiation balance and natural agricultural vegetation. Quartely Journal of Royal Meteorological Society, Berkshire, v. 92, p. 128-140, 1965. 
STEWART, D.W.; COSTA, C.; DWYER, L.M.; SMITH, D.L.; HAMILTON, R.I.; MA, B.L. Canopy structure, light interception and photosynthesis in maize. Agronomy Journal, Madison, v. 95 , p. 1465-1474, 2003.

TASSARO, H. Frutas no Brasil. Disponível em: <http://www.bibvirt.futuro.usp.br>. Acesso em: 27 abr. 2009.

THOMAZIELLO, R.A. O cultivo de cafeeiro em sistema adensado. Disponível em: <http://www.iac.sp.gov.br.>. Acesso em: 27 abr. 2009.

THORPE, M.R. Net radiation and transpiration of apple trees in rows. Agricultural and Forest Meteorology, Amsterdam, v. 19, p. 41-57, 1978.

VALANCOGNE, C.; DAYAU, S.; PIERI, P.; FERREIRA, M.I.; SILVESTRE, J.;

ANGELOCCI, L.R. Influence of orchard and vineyard characteristics on maximal plant transpiration. Acta Horticulturae, Estoril, v. 537, n. 1, p. 61-68, 2000.

WANG, Y.P.; JARVIS, P.G. Description and validation of an array model - MAESTRO.

Agricultural and Forest Meteorology, Amsterdam, v. 51, p. 257-280, 1990.

WANG, S.; CHEN, W.; CIHLAR, J. New calculation methods of diurnal distribution of solar radiation and its interception by canopy over complex terrain. Ecological Modelling, Amsterdam, v. 155, p. 191-204, 2002.

WARREN WILSON, J. Analysis of light interception by single plants. Annals of Botany, London, v. 48, p. 501-505, 1981.

WEISS, A.; NORMAN, J.M. Partitioning solar radiation into direct and diffuse, visible and nearinfrared components. Agricultural and Forest Meteorology, Amsterdam, v. 34, p. 205-213, 1985.

WILLMOTT, C.J. Some comments on the evaluation of model performance. Bulletin American Meteorological Society, Washington, v. 63, n. 11, p. 1309-1313, 1982.

WILlSON, K.C. Coffee, Cocoa and Tea. Cambridge: CABI Publishing, 1999. 195p. 